Florida International University FIU Digital Commons

\title{
Monstrous Maternity: Folkloric Expressions of the Feminine in Images of the Ubume
}

Michaela Leah Prostak

Florida International University, mpros006@fiu.edu

DOI: 10.25148 /etd.FIDC004088

Follow this and additional works at: https://digitalcommons.fiu.edu/etd

Part of the Asian History Commons, Asian Studies Commons, Buddhist Studies Commons, Folklore Commons, Gender and Sexuality Commons, Japanese Studies Commons, Painting Commons, Women's History Commons, and the Women's Studies Commons

\section{Recommended Citation}

Prostak, Michaela Leah, "Monstrous Maternity: Folkloric Expressions of the Feminine in Images of the Ubume" (2018). FIU Electronic Theses and Dissertations. 3714.

https://digitalcommons.fiu.edu/etd/3714 


\title{
FLORIDA INTERNATIONAL UNIVERSITY
}

Miami, Florida

\section{MONSTROUS MATERNITY: FOLKLORIC EXPRESSIONS OF THE FEMININE IN IMAGES OF THE UBUME}

\author{
A thesis submitted in partial fulfillment of \\ the requirements for the degree of \\ MASTER OF ARTS \\ in \\ ASIAN STUDIES \\ by
}

Michaela Leah Prostak 
To: Dean John Stack

Green School of International and Public Affairs

This thesis, written by Michaela Leah Prostak, and entitled Monstrous Maternity: Folkloric Expressions of the Feminine in Images of the Ubume, having been approved in respect to style and intellectual content, is referred to you for judgment.

We have read this thesis and recommend that it be approved.

$\begin{array}{r}\hline \text { Amy Bliss Marshall } \\ \hline \text { Matthew Marr } \\ \hline \text { Steven Heine, Major Professor }\end{array}$

Date of Defense: March 27, 2018

The thesis of Michaela Leah Prostak is approved.

Dean John Stack Jr. Green School of International and Public Affairs

Andrés G. Gil

Vice President for Research and Economic Development and Dean of the University Graduate School

Florida International University, 2018 


\section{DEDICATION}

I dedicate this thesis to my niece, Dylan June Villavicencio, my nephew Bentley Prostak, and my grandfather, Seichi Edwin Sato. 


\section{ACKNOWLEDGMENTS}

I first thank my committee members: Dr. Steven Heine, Dr. Amy Bliss Marshall, and Dr. Matthew Marr, not only for their guidance, patience, and invaluable advice but also for their confidence in me. I also thank Maria Sol Echarren, my SIPA family in the Green School and Asian Studies Program, Lisa Brown for her editorial support, and Marcela Lopez-Bravo for allowing me to drag her all over Tokyo during my fieldwork. Without them, I would not have been able to complete this. I would not have gotten this far without the inspiration and advice from my professors and friends at the College of Charleston and Kansai Gaidai University.

Lastly, I thank my family and friends who helped me when they could and knew when to stay out of my way as I navigated this journey. A special thanks to my mother, who allowed me to rent every horror movie I could get my hands on at the video rental store. 


\section{ABSTRACT OF THE THESIS \\ MONSTROUS MATERNITY: FOLKLORIC EXPRESSIONS OF THE FEMININE IN IMAGES OF THE UBUME}

by

Michaela Leah Prostak

Florida International University, 2018

Miami, Florida

\section{Professor Steven Heine, Major Professor}

The ubume is a ghost of Japanese folklore, once a living woman, who died during either pregnancy or childbirth. This thesis explores how the religious and secular developments of the ubume and related figures create a dichotomy of ideologies that both condemn and liberate women in their roles as mothers. Examples of literary and visual narratives of the ubume as well as the religious practices that were employed for maternity-related concerns are explored within their historical contexts in order to best understand what meaning they held for people at a given time and if that meaning has changed. These meanings and the actions taken to avoid becoming an ubume and interacting with one create a metanarrative that contributes to our understanding of the historical experience of women. 


\section{TABLE OF CONTENTS}

CHAPTER

PAGE

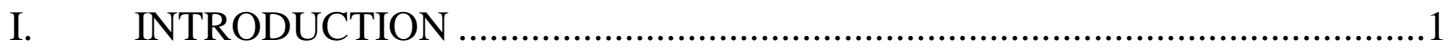

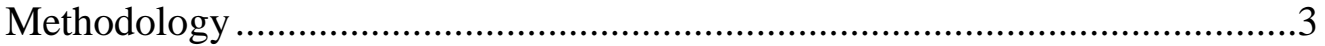

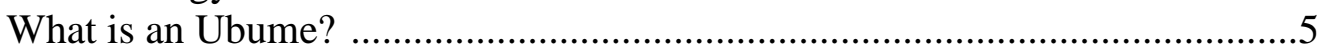

Situating the Ubume within Yōkai Culture ...................................................

Folklore Research in Japan .........................................................................13

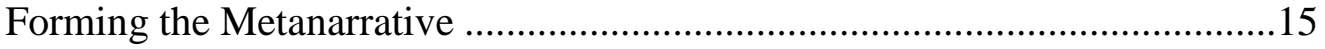

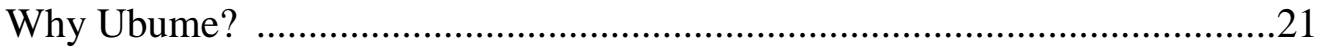

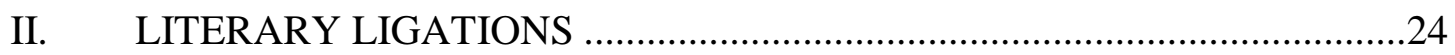

Early Inklings of Defining the Ideal Female Gender Model ...........................25

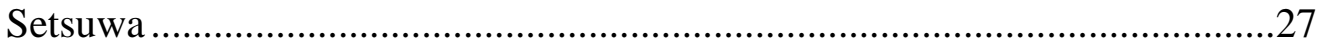

Konjaku - The First Textual Reference Explained …………………...............31

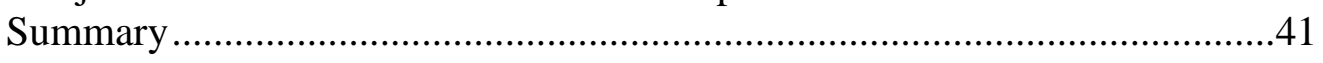

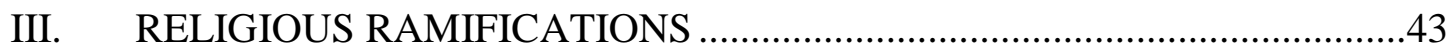

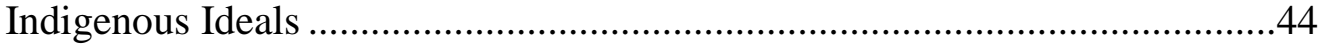

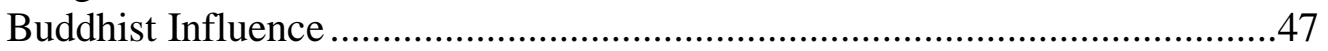

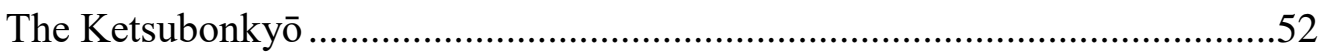

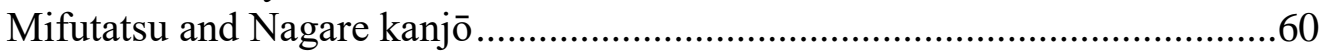

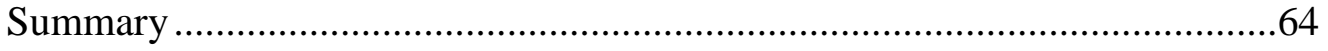

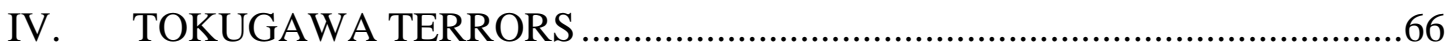

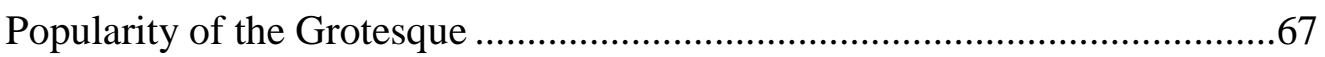

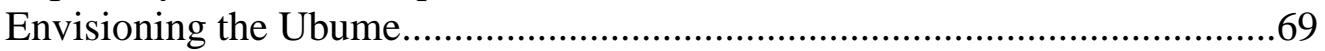

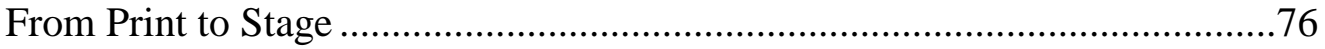

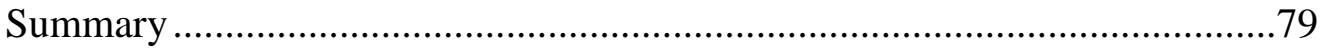

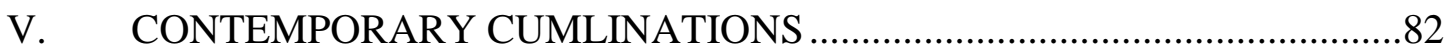

The Place of Folklore in Japanese Society Today ............................................84

The Ubume, Kosodate Yürei, and the Spiritual ..............................................87

Recent Depictions of the Ubume as Abject Mother .......................................92

The Call is Coming from Inside the House! …………....................................97

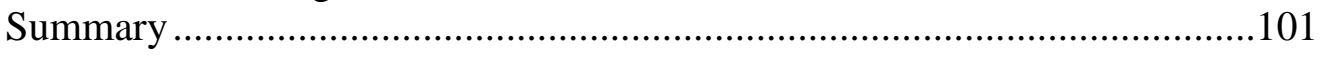

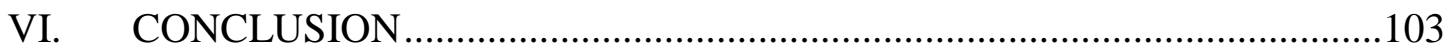

Retracing the Ubume …………………..................................................103

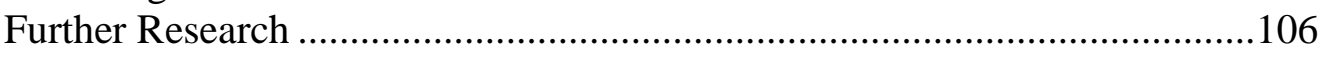

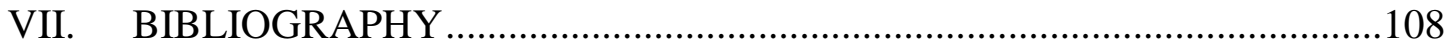




\section{LIST OF FIGURES}

FIGURE

PAGE

1.1 Tokugawa period (1603-1868) artist Sawaki Sūshi’s (1707-1772) rendering of an ubume.

1.2 The ubume depicted as a guhuoniao

1.3 Ideology of motherhood, the stigmatization of non-reproduction, and cultural influences

3.1 Just inside the main entrance of Shōsenji

3.2 A sign displayed at Shōsenji explaining the Ketsubonkyō.

4.1 Banryō's ubume .70

4.2 Toriyama Sekien's ubume

4.3 幽霊之図 うぶめ by Tsukioka Yoshitoshi (1839-1892)

4.4 Nightly Weeping Rock by Utagawa Kuniyoshi (1797-1861) .76

5.1 Kappa mother with children, nursing. .88

5.2 Advertisement for the service posted outside of the temple

5.3 Priests officiating the ceremony with practitioners lined up behind them, waiting to place their dolls into the fire

5.4 A statue of Kosodate Kannon at the Saitama Museum of History and Folklore

5.5 The beginning of the route to the Ubume Kannon temple. A forest to the left, a wall of bushes about waist high to the right

5.6 The entrance to the temple with stone marker and ema (絵馬, votive pictures) in the background

5.7 The Main Hall

5.8 Cover of volume one of the manga adaptation of The Summer of the Ubume (姑獲鳥の夏), featuring Kyogokudo 


\section{INTRODUCTION}

In the pivotal years of the early 1950s, when Japan was in the process of restoring a semblance of normalcy after the devastation of World War II, members of a village carried out what some considered "an act of premodern barbarism." The fetuses of unborn twins were removed from a woman who had died during pregnancy, nearly resulting in the indictment of the family members involved. As folklorist Yamaguchi Yaichirō wrote in his report on the incident, "the relatives and villagers agreed that 'the child she was carrying died shortly before birth, so it is doubtful that she will be able to achieve salvation. She will surely change into an evil spirit, and for seven years her spirit will hang about the eaves of this house and cause trouble." $" 2$

This incident brought two worlds together: the "modernized" and "ordered" world of law in Tokyo and the "premodern" and "chaotic" world of folklore and folk customs related to, broadly, the handling of a death and, specifically, maternity. Folklorists were consulted by law enforcement who did not know how to handle the situation, one of whom was Seki Keigo "who had worked with Yanagita Kunio (1875-1962, the founder of the field of Japanese folklore)."3 However, the prosecutors were not chiefly concerned with the wellbeing of the deceased and her family. Rather, they balked at the idea that "an

\footnotetext{
${ }^{1}$ Manami Yasui, "Research Notes: On Burial Customs, Maternal Spirits, and the Fetus in Japan." U.S.Japan Women's Journal, no. 24 (2003): 110, accessed May 7, 2017, http://www.jstor.org/stable/42771896.

${ }^{2}$ Ibid., 103.

${ }^{3}$ Ibid., 104. Yanagita Kunio spent a great deal of time focusing on maternity related folk practices and collected his findings in the 1930s that led to the Nihon san'iku shüzoku shiryō shūsei (Compilation of Birth-Related Practices in Japan), finished in 1975: Satoko Shimazaki, "THE END OF THE WORLD: Figures of the Ubume and the Breakdown of Theater Tradition," in Edo Kabuki in Transition: From the Worlds of the Samurai to the Vengeful Female Ghost, (New York: Columbia University Press, 2016), 206, accessed April 10, 2017, http://www.jstor.org/stable/10.7312/shim17226.9.
} 
outrageous act based on superstition"4 could possibly take place in the modern society that had been built up in the years following the war. But folklore and folkloric figures are an integral part of Japanese society and spirituality and promulgate and enforce notions relating to death and gender whether people are consciously aware of it or not.

In this thesis, I examine a figure of Japanese folklore called ubume, ${ }^{5}$ the ghost of a woman who died during pregnancy or childbirth, and in doing so synthesize the mélange of literary, historical, religious, and cultural influences on gendered folklore. By tracing the development of the ubume and related figures within the context of the patriarchal Japanese state, highly influenced by Buddhism, I show that even folkloric figures were used as ideological tools of this hegemony to construct gender norms that are still seen today. I refer to this construction as the metanarrative of the ubume.

As recently as the 1950s, there were steps taken to avoid a woman becoming an ubume, and the practice of separating an unborn fetus from the deceased mother was still being performed. Considering that "before the advent of modern diagnostic techniques and the development of emergency medicine...women of all classes were suffering violent deaths in childbirth and failed pregnancies," it is not surprising that practices, both religious and medical, developed to help individuals, and communities, cope with this reality. Figures of folklore solidified these anxieties and ideas in narrative form,

\footnotetext{
${ }^{4}$ Yasui, "Research Notes," 104.

${ }^{5}$ Japanese terms are italicized only the first time they are introduced.

${ }^{6}$ Hank Glassman, "At the Crossroads of Birth and Death: The Blood Pool Hell and Postmortem Fetal Extraction," in Death and the Afterlife in Japanese Buddhism, ed. Jacqueline I. Stone and Mariko Namba Walter (Honolulu: University of Hawaii Press, 2008), 180.
} 
spreading them from rural to urban spaces, from the elite class to the commoners, beginning with didactic literature and later the visual arts.

The 1950s incident exemplifies the order of the modern world being imposed on the perceived chaos of the premodern world, and this order/chaos dichotomy is a recurring theme that will become clear as we trace the chronology of the ubume. It also shows that the fear of this particular type of death would result in a very specific afterlife which would affect not only the deceased but also her relatives, which was an extremely potent and justified fear given Japan's long history of necrosociality, or the relationship between the living and the dead. ${ }^{7}$

\section{Methodology}

The themes of order and chaos, of worlds (natural/supernatural, premodern/modern, pure/impure) colliding, consistently play out in the spiritual landscape of Japan. Folklore can be seen as a manifestation of attempts to come to terms with the unknown and in doing so turn fearful or complicated concepts into more manageable or controllable ones. Instead of denoting yōkai, and attitudes and actions toward them, to the premodern, or barbaric world, it is more beneficial to consider them as the other side of humanity, of one side to the same coin, as will be discussed in a later section of this chapter. For now, it is beneficial merely to take a moment and allow these apparitions to come out of the "nursery" and interact with us the way they would have hundreds of (or even 70) years

\footnotetext{
${ }^{7}$ Jieun Kim, "Necrosociality: Isolated Death and Unclaimed Cremains in Japan," Journal of the Royal Anthropological Institute 22 (2016): 843-863, accessed November 11, 2017, http://onlinelibrary.wiley.com /doi/10.1111/1467-9655.12491/full.

${ }^{8}$ Gillian Bennett, Alas, Poor Ghost!: Traditions of Belief in Story and Discourse (Utah: Utah State University Press, 1999), 1.
} 
ago. As we will see, they are still an "integral part"9 of Japanese society, but with modernity, there is less room, and need for, belief in the fantastical.

After situating the ubume within the broader context of Japanese folklore, in Chapter Two, I show the literary foundations that paved the way for the first textual reference to an ubume that appeared in a work compiled around 1120 . Beginning with the mytho-historical Kojiki (712) and Nihon shoki (720), I contextualize this literature in the historical developments of attitudes towards women, along with the indigenous traditions associated with Shinto and the spread of Buddhism in Japan. The themes of this literature, which cannot be removed from their soteriological purpose, overlap with Chapter Three, which explores more closely the religious ramifications for women and their afterlife. The ideologies promulgated in the literature became actively performed rituals, such as the one enacted in the 1950s incident.

These gender-specific consequences and preoccupation with death ensured that the monstrous would make its way into the art of the Tokugawa period (1603-1868), when a time of relative peace and stability allowed for the proliferation of the visual arts, addressed in Chapter Four. The image of the ubume was solidified at this time, and she was invoked by many painters and even appeared in Kabuki plays. This art continues to inspire contemporary authors and artists. The last chapter explores where the ubume fits in society today, as well as her contemporary connection to spiritual places. Titled "Contemporary Culminations," it explores how the ideologies laid out in early literature and enforced by religious practices continue to form and inform the monstrous mother

\footnotetext{
${ }^{9}$ Noriko T. Reider, Japanese Demon Lore: Oni (Utah: Utah State University Press, 2010), xviii.
} 
metanarrative, exemplified by recent depictions of the ubume. The preeminent contemporary scholar of yōkai, Komatsu Kazuhiko, stresses that "yōkai studies are human studies." 10 Therefore, I did not limit my explorations of the ubume to one approach.

Instead, I utilize an interdisciplinary approach, with archival research done to create a chronology of the ubume and other maternity related narratives, in both textual (secular and religious) and visual (painting and film) representations. These construct the metanarrative of the ubume within the context of yōkai culture. Examples are analyzed within their historical context in order to map the impact of mythology and folklore in defining the role of women. The role of on-site research in Tokyo as well as the smaller towns of Abiko and Shizuoka was to observe contemporary visuals and rites related directly and indirectly to the ubume, such as those at the Ubume Kannon temple in Shizuoka and Shōsenji temple in Abiko.

\section{What is an Ubume?}

An ubume is a phenomenon of Japanese folklore most often categorized as a yōkai (妖怪), an ambiguous term which can be translated as ghost or monster. Usually written as 産女 (giving-birth, woman), ubume are the maternal spirits of women who died either during pregnancy or childbirth. If her unborn baby perished with her, the ubume will attempt to pass it off to someone (consistently a man) who will care for it. Once taken, the ghostly infant typically either becomes as heavy as a stone or turns into a stone, and the ubume

\footnotetext{
${ }^{10}$ Kazuhiko Komatsu, An Introduction to Yōkai Culture (Tokyo: JPIC, 2017), 74.
} 
disappears. In some cases, the person who agrees to take the child is rewarded with great strength if they are able to continue holding the increasingly heavy baby.

If the woman perished while her baby survived, she is usually referred to as a kosodate yūrei (子育て幽霊, child-rearing spirit). This apparition will search for food to provide for her living offspring, either by stealing temple offerings or visiting a candy shop night after night. When she is followed by a curious monk or shopkeeper, she will disappear near her grave. The observer will discover that the apparition has been providing sustenance for a living baby, which is then taken in and raised by the living, generally growing up to be a remarkable person, such as a man of great strength or prosperous monk. In one kosodate yūrei narrative, villagers find a skeleton of a woman clutching a living baby. The skeleton only releases its grip when a living woman proves that she can properly care for her baby by showing she is lactating. ${ }^{11}$

In the first textual reference to the ubume, found in the largest compilation of setsuwa literature compiled in about 1120 , her appearance is not described, although her horrible stench is emphasized. Setsuwa, explored in depth in the second chapter, are tales that are didactic in nature and were often used to enliven Buddhist sermons. During the Tokugawa, or Edo (1603-1868) period, when artists began to produce books and prints to satisfy a growing market of consumers, the ubume's image became fixed: a woman in a kimono drenched in blood from the waist down, cradling an infant in her arms, as in Figure 1.1 below.

\footnotetext{
${ }^{11}$ Michiko Iwasaka and Barre Toelken, Ghosts and the Japanese: Cultural Experience in Japanese Death Legends (Logan: Utah State University Press, 1994), 64.
} 


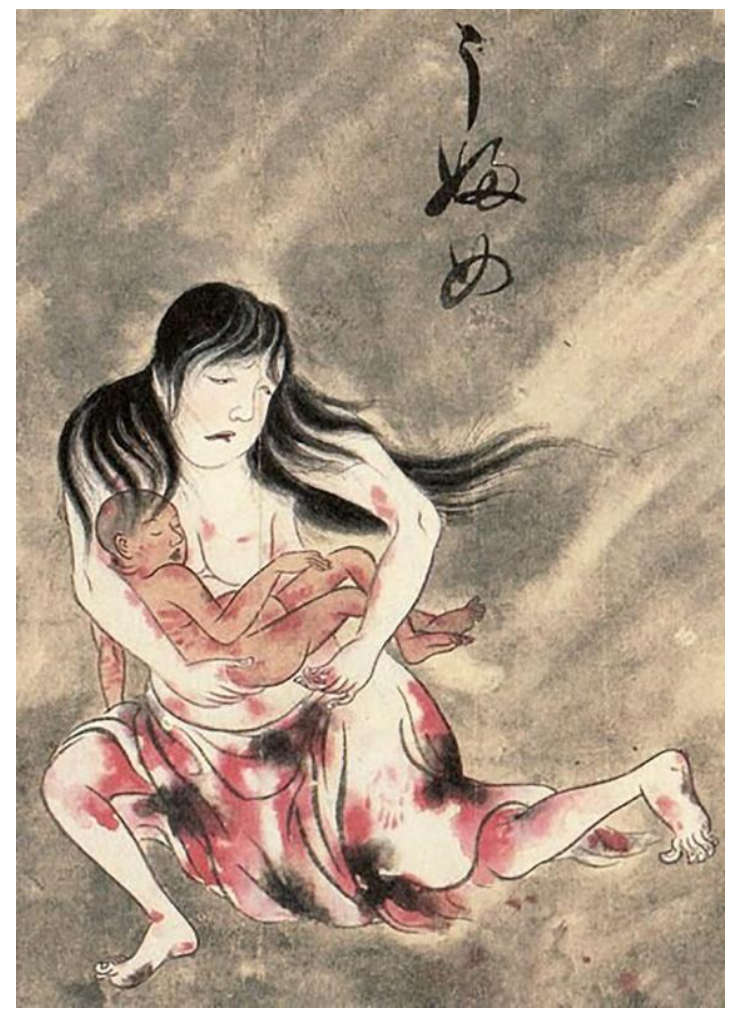

Figure 1.1: Tokugawa period (1603-1868) artist Sawaki Sūshi's (1707-1772) rendering of an ubume. $^{12}$

The characters used to write ubume also allude to her appearance and the way in which she died. As noted, the characters 産女 literally mean birth-giving (産) and woman (女). Many yōkai have been labeled in such a way that denotes their physical characteristics. For example, the kuchi sake onna, or "slit-mouthed woman," (口 kuchi meaning mouth, 裂け sake meaning slit, and 女 onna meaning woman), is the name of another female yōkai that literally has a mouth that is disfiguringly torn. An example of a less violent and more innocuous yōkai, Beto-beto-san, (-san being an honorific similar to the English "sir" or "miss") is named after the sound of wooden sandals on the ground.

\footnotetext{
${ }^{12}$ Money L. Hickman, "Views of the Floating World," MFA Bulletin 76 (1978): 33, accessed December 10, 2017, http://www.jstor.org/stable/4171617. (One time fair usage).
} 
However, as noted in the next section, few concepts in the realm of Japanese folklore are always so straightforward. Another set of characters used to refer to the ubume, often used interchangeably with 産女, 姑獲鳥, which literally mean 姑 mother-inlaw, 獲 seize or find, and 鳥 bird, alludes to a monster of Chinese origin, the guhuoniao, pronounced in Japanese as 'kokakuchō. 13 The narrative of the guhuoniao, or "second meaning, superimposed on the image of the ghost of a woman who died in childbirth or pregnancy, ${ }^{14}$ shares similarities as well as differences with the Japanese ubume. In the 1686 Kokon hyakumonogatari hyōban (古今百物語評判, An Analysis of a Hundred Ghost Stories Old and New), which "offers a Neo-Confucian interpretation of the ubume," a character explains that:

"In China... this bird is a type of evil deity. When it puts on feathers, it turns into a bird; when it takes the feathers off, it turns into a woman. This is what happens after the death of a women in childbirth. For this reason, the bird has breasts and takes pleasure in snatching people's children and making them its own... Originally, this creature must have emerged spontaneously from the corpse of a pregnant woman... Since it originated from the $q i$ 気 [energy] of a pregnant woman, it acts on that nature." 15

For the purpose of this thesis, the distinction is made in an effort to explain why some depictions of the ubume use the 姑獲鳥 set of characters and why at times they appear to have bird-like qualities, as in the depiction in Figure 1.2. This also helps explain why later depictions of the ubume are more malicious than a woman simply wondering around trying to find someone to help her baby. This conflation of multiple

\footnotetext{
${ }^{13}$ Shimazaki, "Figures of the Ubume and the Breakdown of Theater Tradition," 201.

${ }^{14}$ Ibid., 222.

${ }^{15}$ Ibid.
} 
inspirations for one figure it not at all uncommon in the yōkai realm, as there is much regional variation to, and inspiration for, such figures, much of which came from China. As yōkai are cultural products, it is always important to consider the context in which they are mentioned, whether that be in the oral tradition, in a text, a painting, or even a manga or videogame.

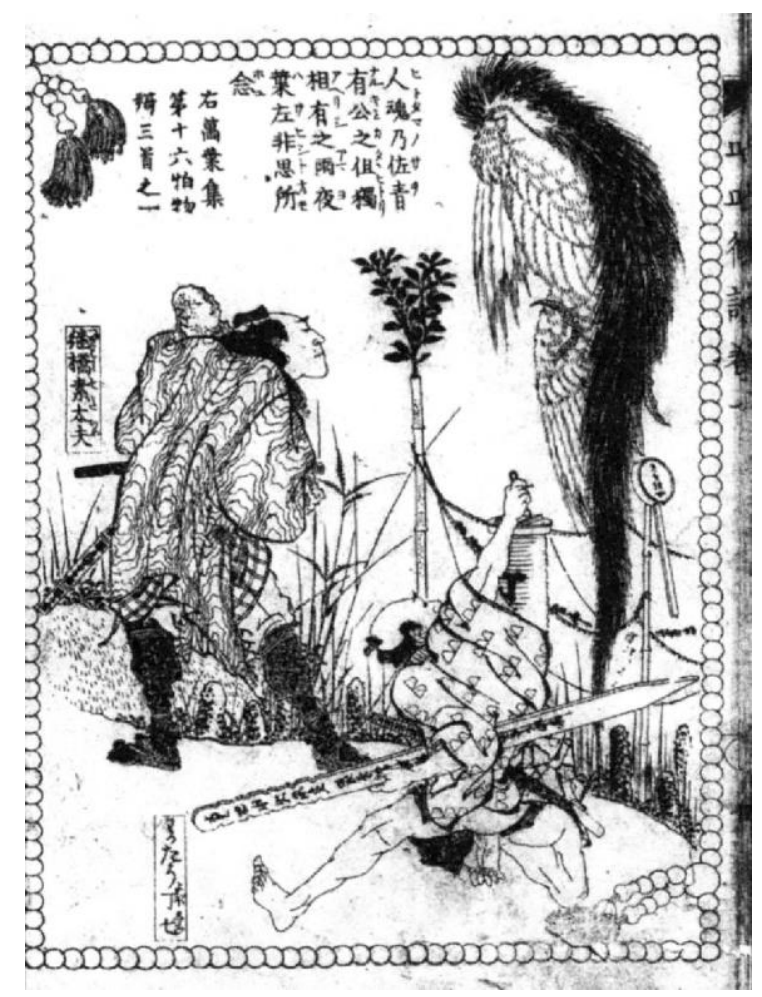

Figure 1.2: The ubume depicted as a guhuoniao. ${ }^{16}$

\section{Situating the Ubume within Yōkai Culture}

As noted, the world of Japanese folklore, and more broadly religion, is ambiguous. It may therefore be instructive to begin by defining the figures that comprise this vast pantheon according to what they are not as opposed to what they are: figures that are not, or no

\footnotetext{
${ }^{16}$ Ibid., 210. This is from an 1815 story called Bei Bei kyōdan, or A Country Tale of Two Sisters, in which "the ghost is not a bird but a woman who asks a man to hold her baby." (One time fair usage).
} 
longer, human. This includes deities related to Buddhism and Shintō (the indigenous tradition of Japan), although these figures are not always divided into distinct Buddhist/Shintō categories. ${ }^{17}$ It also includes figures such as yōkai and yūrei, terms that are slightly more difficult to pin down when taken out of context; in other words, there are approximate characteristics that each term carries but when discussing them in terms of definition, not within the stories or visuals in which they appear, caution must be used.

The term yōkai, written as 妖怪, does not lend itself to an easy translation. 妖 can be translated as bewitching or calamity, and 怪 refers to mystery or apparition. Works on yōkai in English often denote them as monsters, ghosts, or goblins, but these words carry with them their own connotations. Yōkai are not always malevolent or even scary. While some yōkai can certainly be dangerous, many seek only to interact with humans playfully, like the aforementioned Beto-beto-san who simply wants to pass people by on the road. If one hears the sound of footsteps behind oneself but no one is there, one can politely tell him to pass and the eerie sound will stop.

The term yūrei (幽霊) is most comparable to the ghosts in Western literature and cinema, although "the Western ghost... is much less common and not as dangerous," cautions Brenda Jordan. ${ }^{18}$ 幽, meaning dark, or faint, and 霊, meaning spirits or souls, the term yūrei refers to deceased individuals who have not been able to achieve peace in the

\footnotetext{
${ }^{17}$ For example, a Shintō kami (神, deity) may be absorbed into the Buddhist pantheon of gods and goddesses, as in the case of Suiten (水天). Buddhism integrated a water deity of Hindu origins, Varuna, and when it spread through Japan, incorporated various water kami into this amalgamation (Mark Schumacher, “Suijin 水神, Suiten 水天, Sui-̄̄ 水王," Onmark Productions, accessed November 30, 2017, http://www.onmarkproductions.com/html /suijin.html).

${ }^{18}$ Brenda Jordan, "Yürei: Tales of Female Ghosts," in Japanese Ghosts \& Demons, ed. Stephen Addiss (New York: George Braziller, 1985), 25.
} 
afterlife. While yōkai are generally associated with a certain location and do not seek out specific individuals, yūrei typically appear near those that knew them while they were alive, as in perhaps the most famous Japanese ghost story, Yotsuya kaidan, written by Tsuruya Nanboku IV. Originally a kabuki play written in 1825 , the story revolves around the vengeful female ghost of Oiwa who was wronged and poisoned by her husband. ${ }^{19}$

It must also be noted that the terms yōkai and yūrei, however useful they may be now, were not always used to refer to these beings. The term yūrei first appeared in Heian period (794-1185) literature, although references to beings that have characteristics of yūrei can be found in earlier texts. ${ }^{20}$ The term yōkai only began to be widely used in the late 1800's when philosopher Inoue Enyrō attempted to disparage belief in "superstitions hindering Japan's modernization." ${ }^{21}$ As anthropologist Komatsu Kazuhiko points out, "in ancient times, uncontrolled spiritual presences were often referred to as oni. Any and all characteristics deleterious to humans were ascribed to these $o n i, " 22$ but as these presences were named and then categorized, they came to be thought of as separate from oni. Oni is written with 鬼, which is often translated as devil or demon. ${ }^{23}$

This makes the case of the ubume unique in this mysterious realm in that she has characteristics of both a yōkai and yūrei; she was once a living woman who became an

\footnotetext{
${ }^{19}$ Satoko Shimazaki, “The Ghost of Oiwa in Actor Prints: Confronting Disfigurement," Impressions, no. 29 (2007): 78-79, accessed July 13, 2017, http://www.jstor.org/stable/42598014.

${ }^{20}$ Kazuhiko Komatsu, Yōkai Culture, 134.

${ }^{21}$ Ibid., 68.

22 Ibid., 17.

${ }^{23}$ For an in-depth analysis on oni specifically, see Noriko T. Reider, Japanese Demon Lore: Oni from Ancient Times to the Present (Logan: Utah State University Press, 2010).
} 
apparition after death but she does not pursue those that she knew in her life time and has, in a sense, lost her humanity. In fact, the appearance of an ubume became a community concern, akin to the distress of dealing with the dangers of a health epidemic or natural disaster, which is discussed later on in depth. Even in the instances in which her baby survives her, and she falls under the moniker of kosodate yūrei, she does not attempt to interact with those that she knew in her lifetime. Instead, her only goal is to provide sustenance for her baby (in contrast to the ubume who attempts to find someone to care for her ghostly infant). However, I posit this distinction is due to the fact that the kosodate yūrei interacted with her human child, who remains in the world of the living. Despite the vague and at times contradicting nature of these beings, there is some order in the chaos. The supernatural world is governed by rules just as the natural world is. The Konjaku monogatari, which includes the first textual reference to an ubume and is explored in depth in the next chapter, contains multiple examples of encounters with the supernatural and how such encounters should be handled. There has always been a "good" and a "bad" side in the spiritual world of Japan, and those sides can either be changed, controlled, exploited, or manipulated. All of the aforesaid beings contain both sides. Kami, the deities of the Shintō tradition, are not omniscient, nor are they always benevolent. Yōkai can be prayed to, and placated, to then become kami. Even humans can potentially become kami. ${ }^{24}$ On the other side of the spectrum, humans also have the

\footnotetext{
${ }^{24}$ These are referred to as Tenjin, a living human who is deified after death (Mark Schumacher, "Shrines by Type, Shrines by Kami (Deity)," Onmark Productions, accessed November 30, 2017, http://www.onmark productions.com/ html/shrine-guide.shtml\#tenjin). Sugawara no Michizane is perhaps the most well-known Tenjin, and after he was banished from the court, upon death, his spirit caused harm to the living. To mitigate this, he was deified and is now worshipped widely throughout Japan at shrines and temples alike.
} 
potential to become an unhappy spirit, a fate that an entire culture surrounding necrosociality, or the relationship between the living and the dead, developed to avoid.

\section{Folklore Research in Japan}

The serious academic field of folklore research in Japan began with Yanagita Kunio (1875-1962), mentioned above, who was spurned by the fear that the modernization of the early 1900s was eroding the traditions of rural village life. He "insisted that there were classic folktales that were mythological in nature," 25 and attempted to show this connection by systemically collecting ethnographic data, significantly oral folktales of the Tono region of Northern Japan. This was in sharp contrast to the philosopher Inoue Enyrō who had devoted much of his career to showing that yōkai were nothing more than superstition. However, Yanagita's research was driven largely by the idea of inasaku ichigenron (稲作一元論), or “rice cultivation monism." ${ }^{26}$ In other words, he worked under the assumption that "the Japanese archipelago was established in a homogenous rice cultivating tradition." By assuming this, he left out groups that did not fit into this category. ${ }^{27}$ This limited his focus and therefore his findings, which he also tended to edit however he saw fit.

\footnotetext{
Often represented as a bull, he is known for being particularly helpful with scholastic endeavors, and students take advantage of this by rubbing the head of the bull.

${ }^{25}$ Hiroshi Kawamori, "Folktale Research after Yanagita: Development and Related Issues," Asian Folklore Studies 62, no. 2 (2003): 237-256, accessed November 15, 2016, http://www.jstor.org/stable /30030288.

${ }^{26}$ Takanori Shimamura, "Cultural Diversity and Folklore Studies in Japan: A Multiculturalist Approach," Asian Folklore Studies 62, no. 2 (2003): 197, accessed November 15, 2016, http://www.jstor.org/stable 130030286.

${ }^{27}$ Ibid.
} 
Yanagita's work has been both beneficial and a detriment to Japanese folklore studies. The idea of rice cultivation monism stayed, and today we see remnants of this in Nihonjinron discourse, or the idea that Japanese culture is distinct or unique, which limits comparative studies and again assumes a grossly oversimplified homogeneity. Many have since taken on invaluable endeavors in the world of Japanese folklore, attempting to bring to focus groups that Yanagita would have left out or glossed over. However, the trap of essentialism is very easy to fall into, and the trend has been to examine aspects of folklore as isolated or insular "case studies," which does not lend itself to creating an established academic discipline. Moreover, while there are scholars such as Amino Yoshihiko (1928-2004) who attempted to stress more cultural diversity within Japanese folklore, much of the discourse has been too insular to provide any benefit for folklore research beyond the Japanese context.

That being said, the work of those scholars has been immensely valuable. Without their early efforts, much of the oral tales collected may very well have been lost to history. Yanagita was on the right track when he recognized the importance of recording oral traditions: as Iwasaka and Toelken point out, "a legend represents an articulate dramatization of cultural meaning." ${ }^{28}$ Today, more people are aware that a holistic approach is needed to benefit the academic study of Japanese folklore and more specifically yōkai. Indeed, it is my hope that by explicating the development of the ubume, this thesis will offer a stepping stone of sorts to further research into gendered folklore.

\footnotetext{
${ }^{28}$ Iwasaka and Toelken, Ghosts and the Japanese, 43.
} 


\section{Forming the Metanarrative}

Within the context of the ideology of motherhood, the quote from Simone de Beauvoir's The Second Sex "one is not born a woman, but rather becomes one," ${ }^{29}$ takes on a particularly potent meaning in Japan; to be a woman is to be a mother. The ideology of motherhood creates pressures for women to have children and also stigmatizes nonreproduction. The social norm is for women to have children, with pressures coming from various spheres. ${ }^{30}$ Throughout this thesis I show that despite shifts in attitudes towards women's bodies over the course of Japanese history, exemplified by attitudes and actions taken towards the ubume, women were still expected to produce children and have always been situated within society based on their relationship with men. Figure 1.3, below, shows a graph detailing the overlying ideology of motherhood, the underlying factor of the stigmatization of non-repoduction, and the mélange of indivisible cultural attitudes and religious beliefs in which the narratives of figures such as the ubume are situated. These, in turn, form and inform the metanarative, or everything that happens surrounding the narratives.

While the traditions of Shintō and Buddhism that had direct impacts on the lives and spiritual place of women are explored in depth in chapter three, it would be helpful to

\footnotetext{
${ }^{29}$ Simone de Beauvoir, The Second Sex (New York: Vintage Books, 1973), 301.

${ }^{30}$ For an in-depth look on this specifically, see Kumiko Nemoto, "Postponed Marriage: Exploring Women's Views of Matrimony and Work in Japan," Gender and Society 22, no. 2 (2008): 219-237, accessed October 1, 2017, http://www.jstor.org/stable/27821634 and Rebecca L. Richko, "Social and Economic Factors Influencing Japanese Women's Decision about Childbearing in Post-Bubble Japan," (2016), FIU Electronic Theses and Dissertations. 2451, accessed July 15, 2017, http://digitalcommons.fiu.edu/etd/2451.
} 
offer a cursory glance at the "vivid manifestations of belief, psyche, and imagination"31 that contribute to the themes in the chart above. Nature and the belief in the transformation of animals, as well as objects, contributes to an animistic worldview, stressing that anything and everything can be the "potential abodes for spirits and deities and that they must be treated with care and respect." Although there are separate spaces for deities, the living, and the dead, these are incredibly liminal and interconnected. ${ }^{32}$ Because of this, interaction with deities and spirits was not seen as completely out of the ordinary. Tatari, which originally referred to repercussions from kami, came to be seen as misfortune caused by spirits, who were most often muenbotoke, or "restless spirits with "no relations" (muen) to ritualize them properly." 33

\footnotetext{
${ }^{31}$ Akira Y. Yamamoto, introduction to Japanese Ghosts \& Demon: Art of the Supernatural, ed. Stephen Addiss (New York: George Braziller, Inc., 1985), 9-12.

${ }^{32}$ Ibid.

${ }^{33}$ Helen Hardacre, Marketing the Menacing Fetus in Japan (Berkeley: University of California Press, 1997), 2-3.
} 
IDEOLOGY OF MOTHERHOOD

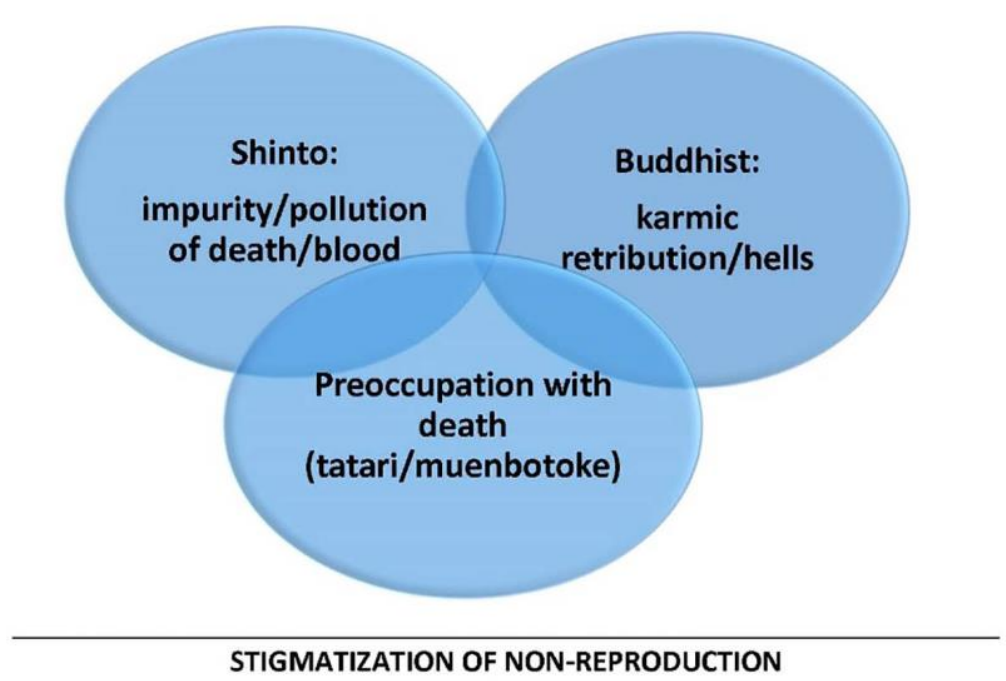

Figure 1.3: Ideology of motherhood, the stigmatization of non-reproduction, and cultural influences.

Another important aspect of the spiritual landscape in Japan is the syncretism of Shintō, Buddhism, and the state. While the power dynamics of these three institutions have continuously shifted throughout different periods in Japanese history, their interconnectedness contributes to a religious atmosphere that makes the three domains categorized by an indivisibility. Buddhism was used as an ideological tool of those in power as early as the Asuka period (552-645), as various powerful competing families came to adopt it. In opposition, there were also powerful families that asserted adherence to kami. ${ }^{34}$ In this respect, the religious atmosphere in Japan can be considered to be made up of various religious ingredients and not so much cookie-cutter religion. That being

\footnotetext{
${ }^{34}$ William E. Deal and Brian Ruppert, A Cultural History of Japanese Buddhism (West Sussex: Wiley, 2015), 28-29.
} 
said, it is important to note how some of these things contributed to the development and fear of the ubume.

Within Shintō, "purity and taboo" are emphasized. ${ }^{35}$ As Thomas P. Kasulis points out, the difference between taboo (or defilement, tsumi 罪) and sin lies in the "intent" of the action: "sin usually cannot be accidental," but the "diluting" of purity can be accidental. The two main defilements are death and blood, which, obviously, cannot be avoided, and are therefore "not intentional acts." These notions of tsumi may not have originally been designed to actively oppress woman. Rather, they suggest that "Shinto is strongly associated with life: fertility, physical health, creation, and abundance." ${ }^{36}$ As the opposite of this, death and blood (associated with death), are tsumi. This puts women at a disadvantage, and indeed negative attitudes towards them, and their polluted bodies, have been observable since premodern Japan. The female body is, at the same time, also associated with life in the form of fertility, a contradiction that makes figures like the ubume all the more essential in navigating this spiritual landscape.

Much of what we know about early Shintō ideals is found in the Kojiki (712), a mythical history of the Japanese islands. In one story, the male kami Susano-o receives food from a woman that has come from various parts of her body. "Offended by her actions and convinced that this food is polluted," he "flies into a rage and kills her," but from her body comes such staples as millet, beans, and wheat. ${ }^{37}$ Such myths help us

\footnotetext{
${ }^{35}$ Thomas P. Kasulis, Shinto: The Way Home (Honolulu: University of Hawaii Press, 2004), 47.

${ }^{36}$ Ibid., 48-49.

${ }^{37}$ Barbara R. Ambros, Women in Japanese Religions (New York and London: New York University Press, 2015), 7-8.
} 
understand the underlying views of women as well as the scarce evidence of prehistoric Japan, mainly the Jōmon period (about 1000-300 BC) that include perplexing female clay figures. While these myths were retroactively imposed over history, or "layered over" as Barbara R. Ambros puts it, they show that "the female body, though suspected of pollution... yields valuable sustenance..."38

With this ambivalent attitude towards the female body already in place, we can see how Buddhist notions of male superiority were accepted and spread into the culture of Japan, mainly in the form of karmic retribution and hells. While the Shintō-esque creation myths of the Kojiki were being compiled, Buddhism had already made its way into Japan via Korea. While "scholars have debated the role of early female rulers in the sponsorship of Buddhism," it is interesting that "during the first two centuries of Japanese Buddhism, women played important roles," both in patronage and active participation as nuns. However, early examples of the Lotus Sutra, arguably one of the most influential texts on Buddhism in Japan, and particularly in regards to gender, contained multiple examples of the superiority of males over females. ${ }^{39}$

In addition, beginning in the Nara period (710-794), the state began setting forth rules and regulations for monastics. While these did not initially single out females, they were influenced by "Confucian values of loyalty, fidelity, and filiaity," which place women in an inferior position to men. Ambros stresses that during this time, the more severe notions of female defilement and pollution were not present, and did not take firm

\footnotetext{
${ }^{38}$ Ibid., 9.

${ }^{39}$ Ibid., 45-47.
} 
root until the Heian period (794-1185). ${ }^{40}$ While I agree with this, and view the relationship between women and Buddhism until the Heian period as a sort of honeymoon phase, I do believe that it is possible to see early inklings of female inferiority in the Buddhism of the Nara period.

As these inklings of the spiritual inferiority of, or at least ambivalent attitudes towards, women show, interpreting folktales of yōkai and yūrei merely as entertainment would not be sufficient to explain why they linger, in the shadows, despite the periods of modernization Japan has gone through. As with the lawyers from Tokyo that were appalled by the villager's decision to separate the woman from her unborn fetuses in the opening anecdote, there have been instances in which influential individuals have actively sought to eradicate notions of yōkai and the mysterious, such as Inoue Enryō who "devoted himself to the study of yokai in order to help Japanese people become aware of their ignorance and unscientific ways of thinking during an era of modernization." ${ }^{41}$ However, if we do not consider them alongside the major influences of religious institutions and major historical trends, the picture is incomplete. And, as the proliferation of yōkai in media today attest to, Enryō was unsuccessful in his attempts to rid Japan of its vast pantheon of supernatural entities.

\footnotetext{
${ }^{40}$ Ibid.

${ }^{41}$ Ikeda Masayuki, "Messages from Yūrei and Yōkai —Koizumi Yakumo and Inoue Enryo on Yōkai," Yomiuri Shimbun, accessed September 20, 2016, http://www.yomiuri.co.jp/adv/wol/dy/opinion/culture _150924.html.
} 


\section{Why Ubume?}

In 1994, the ubume became a "best-selling yōkai" thanks to novelist Kyōgoku Natsuhiko, "current star of the creative yōkai world," 42 who used the ubume motif in his debut novel, Ubume no natsu (姑獲鳥の夏, The Summer of the Ubume). ${ }^{43}$ Kyōgoku uses the image of the ubume to relate to a woman who has been pregnant for twenty months. The work, which weaves through a hardboiled detective story well known folklore tropes as well as the lesser known origins, religious connotations, and psychology behind them, is ultimately a historical and psychological analysis of folklore's place within society disguised as a mystery novel. By choosing the ubume, which is arguably not as popular as other yōkai (such as the kuchisake onna), Kyōgoku was bringing focus to the themes this figure embodies that have not been able to find the same kind of outlets as they had in the past. As mentioned above, one would not be getting the full picture by denoting yōkai and yūrei to mere spooky stories, even if they can certainly be enjoyed as such. Placing them into such a limited category is akin to Yanagita Kunio operating under the assumption that Japanese culture derived from one source; it may be easier for a scholar to examine just one piece of the puzzle, but the picture would then be incomplete. Consider the popular Western urban legend of the tale of the Hook hand on Lover's Lane, in which two teenagers narrowly escape being slaughtered by an escaped maniac with a hook for a hand. The actual embellishments to the tale vary (sometimes they both survive, sometimes the boyfriend is killed) but the tale itself developed out of a moral

\footnotetext{
${ }^{42}$ Michael Dylan Foster, The Book of Yōkai (Oakland: University of California Press, 2015), 70.

${ }^{43}$ Natsuhiko Kyōgoku, The Summer of the Ubume (New York: Vertical, 1994).
} 
panic over the sexual promiscuity of teenagers, a fear that is repeatedly played up in Western cinema. Such legends have staying power precisely because they touch on societal fears and anxieties. Similarly, it is important to consider the culture context when analyzing stories of yōkai and yūrei.

In other words, the anxieties surrounding pregnancy can no longer be filtered by supernatural explanations. Noriko T. Reider's summation of the development of oni can easily be applied to the ubume as well: “As society becomes more secular and religion's influence recedes, the oni's power and influence wane." 44 However, as explored in the last chapter, this does mean the monstrous mother has disappeared completely.

In the case of the ubume, as we will see, the notions of the impurity of blood put living women at a disadvantage. The fear of tatari and muenbotoke put women who died particularly violent or tragic deaths at a disadvantage. Moreover, since pregnancy, before the advent of modern medicine, was such a death that occurred regardless of class the figures of the ubume and kosodate yūrei developed, in addition to measures taken to avoid becoming one and to avoid interaction with one. Given the perpetually dismal reality of gender inequality in Japan, compounded by the nation's low birth rate and aging population, the ideology of motherhood and stigmatization of non-reproduction are still pervasive. By following the trajection of a gendered figure of folklore, we gain valuable insight into the female historical experience. These figures were important

${ }^{44}$ Reider, Japanese Demon Lore, 182. 
ideological tools and since folklore is "often hidden in full view," 45 their messages, when used to control or condemn, can be incredibly dangerous and powerful.

${ }^{45}$ Mary Hufford, "American Folklife: A Commonwealth of Cultures" in Folk Nation: Folklore in the Creation of American Tradition, ed. Simon J. Bronner (Wilmington: Scholarly Resources Inc., 2002), 238. 


\section{LITERARY LIGATIONS}

What led to the first textual reference to an ubume, found in the Konjaku monogatari, compiled around 1120 ? This chapter explores the literary foundations that paved the way for not only later Japanese literature but the flourishing of the performing arts during the Tokugawa period in which the ubume and other folkloric figures proliferated.

Throughout this early literature, the feminine was consistently and overtly used to represent chaos while the masculine to represent order. However, the feminine was not always treated with disdain, and many works make it clear that from the fecundity of the feminine comes life-giving benefits. It was from these irresolute attitudes towards the female body that the figure of the ubume developed.

The aesthetics of Heian court literature stressed that "emotions had to be carefully packaged in poetic expression" and the emotions of women were often "expressed metaphorically" with demons. The "didactic lesson" of such a metaphor warned women not to show "rage and jealousy (lest they turn into demons) and men against pursuing affairs with an unknown woman (lest she turn out to be a cannibalistic demon)." This trend echoes the stories found in the preceding Nara period Kojiki and Nihon shoki in that it shows the man to be more innocent and the woman to be demonic, sometimes literally, and again emphasizes the themes of order (male) and chaos (female). While in some cases, as in the story of a pregnant mother facing an oni in the Konjaku monogatari discussed below, a woman encounters a female demon, “...it is undeniable that the tales simultaneously were influenced by and contributed to the growing demonization of 
women and their bodies from the Heian period..." onward. ${ }^{46}$ The overlying anxiety related to the Buddhist concept of mappō, or the notion that the further in time from the death of the Gautama Buddha the more difficult it is for a person to be able to achieve salvation, made the lessons held in such literature all the more important. Early Inklings of Defining the Ideal Female Gender Model

Before discussing the first textual reference to the ubume, found in the Konjaku monogatari, the largest compilation of setsuwa, or doctrinal tales, it is necessary to examine briefly the literary foundation in which this text appeared, beginning with the Nihon shoki, or Chronicles of Japan, compiled in 720.

Because the transmission of Buddhism to Japan was "intimately connected with struggles over the consolidation of political power," it is not surprising that the "imperial command" had the Nihon shoki compiled in a time when various clans were all vying to legitimize their claims to power. While Deal and Ruppert point out that the Nihon shoki, as the "official" account of the transmission of Buddhism into Japan, is "retrodictive," it is important because it stressed the materiality of Buddhism (such as sutras) and treated Buddhism itself as an object that was to be used by those in power. ${ }^{47}$

In other words, this was the beginning of the control of the state over religious practices and ideologies that were eventually emulated by the majority. The significance of this in terms of ritual practices, such as those that developed in relation to the ubume, is discussed later. However, for now, it is important to stress that the Nihon shoki was

\footnotetext{
${ }^{46}$ Ambros, Women in Japanese Religions, 60-61.

${ }^{47}$ Deal and Ruppert, A Cultural History of Japanese Buddhism, 13-31.
} 
written to be an ideological collar and leash. If Buddhism, "portrayed as the possession of the imperial family and the central government, ${ }^{, 48}$ was indeed such, we can see how easily the non-elites would adopt the practices that the elites adopted, such as reading and copying sutras for deceased family members. The Nihon shoki also contains the notion of karmic retribution, as opposed to tatari (punishment from kami) although not yet specifically for women.

Before turning to the first compilation of setsuwa tales, it is also helpful to note another story from the Kojiki, compiled shortly before the Nihon shoki; the creation myth of the Japanese island and its people. The tale involves a pair of deities, Izanami (female) and Izanagi (male). Izanami discovers that her body is insufficient, while Izanagi discovers that his "is formed to excess," and inserts this part of himself into her to procreate. However, because Izanami speaks before Izanagi, their child is "malformed." 49 The version found in the Nihon shoki, while not as damning for Izanami, still depicts femininity as "dark, yielding, and destructive."

Particularly pertinent to the formation of the ubume trope is the ending to their tale, found in both the Kojiki and the Nihon shoki versions. Izanami dies after giving birth, and although she is not referred to as an ubume, in death she vows to wreak havoc

\footnotetext{
${ }^{48}$ Ibid., 21.

${ }^{49}$ Ambros, Women in Japanese Religions, 27. Interestingly, they send the child off into the ocean, not unlike some of the practices of mabiki, or infanticide, practiced by individuals who for various reasons did not feel that they had the means to raise a child. In some cases, this was seen "less as a desperate act in the face of poverty than as a form of family planning," Thomas C Smith, Robert Y. Eng, and Robert T. Lundy, Nakahara: Family Farming and Population in a Japanese Village, 1717-1830 (Stanford: Stanford University Press, 1977), 61.

${ }^{50}$ Ibid., 28.
} 
by taking " 1,000 lives daily," while "Izanagi counters that he will ensure the birth of 1,500 daily." As Ambros points out, Izanagi, the male, represents order, while Izanami, the female, represents chaos. While it would be overly simplistic to impose this story on gender relations of actual living people, it still embodies the ambivalent attitudes of purity and the duality of the female body as both polluted and fecund. ${ }^{51}$ Hardacre also points out that "within this relation of gender complementarity, the male should take the initiative, and the female should yield and assent. When those conditions are met, their union is successful." ${ }^{, 52}$

\section{Setsuwa}

Setsuwa, written as 説話 (the characters for explanation and tale), is a literary genre distinct from the earlier works of "mythological nature" 53 like the Nihon shoki mentioned above. They can be considered anecdotes, "defined as the narration of an individual event, or a series of events. ${ }^{" 54}$ Events that, in the context of setsuwa, "embellishes and works to make more aesthetic things which apparently occurred in the secular world." 55 In other words, the potency of setsuwa derives from their connection to our world, not the world of gods, although many do include trips to hell, such as chapter nine of the

\footnotetext{
${ }^{51}$ Ibid., 29-30.

${ }^{52}$ Helen Hardacre, Shinto: A History (New York: Oxford University Press, 2017), 52.

${ }^{53}$ Kōzō Kurosawa, “Myths and Tale Literature," Japanese Journal of Religious Studies 9, no. 2/3 (1982): 115-125, accessed December 10, 2017, http://www.jstor.org/stable/30233943.

${ }^{54}$ Ury describes Konjaku as "an anecdote depicting a world," and indeed it covers "all three countries of the known world, all provinces of Japan, and the activities of persons of every class of society," (Marian Ury, Tales of Times Now Past (Ann Arbor: The University of Michigan, 1979), 3-10.

${ }^{55}$ Kurosawa, "Myths and Tale Literature," 120.
} 
Konjaku monogatari, or miraculous tales, such as those found in chapters sixteen and seventeen of Konjaku monogatari. Because the "life of any setsuwa is derived from its interest," the stories combine elements that are "out of the ordinary" with real individuals, real people, and real places. ${ }^{56}$ As Davidsen points out in regards to the efficacy of the supernatural to afford religious belief, "a text must present those supernatural beings as real within the story-world; to afford ritual interaction with said beings, a text must include model rituals and inscribe the reader into the narrative; to afford belief in the historicity of the narrated events, a text must anchor the story-world in the actual world." 57

This genre, which developed as "the earliest attempt in Japanese Buddhism to find a popular literary genre capable of expressing complex aspects of abstract doctrine in concrete, sensually verifiable, and compelling narrative terms," were "also linked intimately to performance, to the public and popular venue of the sermon." This was extremely important in that it allowed them to "transcend class boundaries"58 in a time when only the elites could read and write. Due to this performative nature, this genre also

\footnotetext{
56 Ibid.

${ }^{57}$ Markus Altena Davidsen, "Fiction and Religion: How Narratives About the Supernatural Inspire Religious Belief - Introducing the Thematic Issue,” Religion, 46:4 (2016): 489-499, DOI:10.1080/0048721X.2016.1226756.

${ }^{58}$ Charlotte Eubanks, "Illustrating the Mind: "Faulty Memory" Setsuwa and the Decorative Sutras of Late Classical and Early Medieval Japan,” Japanese Journal of Religious Studies 36, no. 2 (2009): 210-211, accessed September 2, 2017, http://www.jstor.org/stable/40660966.
} 
helped pave the way for the development of "pictorial preaching, known as etoki," popularized in medieval Japan and still performed today. ${ }^{59}$

Nihon ryoiki, the first setsuwa collection and predecessor of the Konjaku, is short for “Nihonkoku genpo zen'aku ryōiki, (日本国現報善悪霊異記)” or “Miraculous Stories of the Reward of Good and Evil from the Country of Japan. ${ }^{\circ 60}$ It's pages are full of karmic retribution not just in the afterlife but in this life as well. One of the recurring themes is "immediate" penalty or reward, stressing the "different ways in which the law of karmic causality is manifested." Like many of the stories in the Konjaku (which may have derived inspiration from this earlier work) the Nihon ryōiki is an attempt to spread Buddhist doctrine to the "lower level of society." ${ }^{61}$ Although many of the stories are set prior to the Heian period, the idea of mappō still underlined the urgency of the events. Stylistic of setsuwa, the stories in the Nihon ryoiki are short and "plot and action driven" and arranged in a decisive manner, in this case chronological. ${ }^{62}$

How is the female body treated in the Nihon ryoikit? Raechel Dumas addresses the contradictory unease with which the female body is, "figured as an object of simultaneous desire and disgust." ${ }^{\circ 3}$ The ubume not does appear in this text but many of

\footnotetext{
${ }^{59}$ Ikumi Kaminishi, Explaining Pictures: Buddhist Propaganda and Etoki Storytelling in Japan, (Honolulu: University of Hawaii Press, 2006), 3.

${ }^{60}$ Haruo Shirane, introduction to Record of Miraculous Events in Japan, translated by Burton Watson (New York: Columbia University Press, 2013), 4.

${ }^{61}$ Ibid., 1-3.

${ }^{62}$ Ibid., 5 .

${ }^{63}$ Raechel Dumas, "Historicizing Japan's Abject Femininity: Reading Women's Bodies in "Nihon Ryōiki,"'Japanese Journal of Religious Studies 40, no. 2 (2013): 247-248, accessed March 4, 2017, http://www.jstor.org/stable/23595655.
} 
the narratives and their themes mirror those found in the Konjaku and profoundly affected the perception of not only the female form but giri (duty), karmic retribution, and attitudes towards family and the dead. Because the stories found in this text are "thought to have been transmitted outside of religious sites and among listeners residing within both trade cities and peripheral communities," 64 it offers invaluable insight into the cultural atmosphere at that time beyond what the state demanded be included in the Kojiki and Nihon shoki.

Tale thirteen, of volume one, offers a story about how a mother should act. It features an incredibly pious woman who bore seven children and despite being poor, cleans herself every day and provides clothing and food for her offspring. One day, she flies up to Heaven. The ending remark of the story is, "Even though you live the life of a layperson, if you sweep the garden with a pure heart, you will gain five kinds of merit." 65 This story not only demonstrates immediate karmic reward for her actions, it also ties in the notion of purity by stressing cleanliness.

Other tales, "one-fifth" of them, address "female transgression." 66 Story nine, in volume three, details the account of a man who travels to hell where his wife was suffering after dying in childbirth. He learns from King Yama (the king of hell) that "she has been condemned to suffer for six years. She has already spent three years here and

\footnotetext{
${ }^{64}$ Ibid., 250.

${ }^{65}$ Watson, Record of Miraculous Events in Japan, 33-34.

${ }^{66}$ Dumas, “Historicizing Japan's Abject Femininity,” 261.
} 
has three years to go." ${ }^{97}$ His wife requested that he suffer with her of the remainder of her sentence, but when the man agrees to copy the Lotus Sutra, his wife and King Yama agree to let him go back to the world of the living. Again, the female in this story suffers while the male does not. However, this early example also shows the idea of a family member atoning for a loved one who is suffering in hell.

\section{Konjaku - The First Textual Reference Explained}

The first textual reference to an ubume is found in the Konjaku monogatari shū, (今昔物語 集), “Tales of Times Now Past,” compiled during the Heian period (794-1185), most likely around 1120.68 “'Monogatari, literally 'a telling,' is a word for tales or narratives of any kind; shü means collection or anthology; konjaku is the Sino-Japanese pronunciation for the two Chinese characters in the formulaic phrase with which each tale opens." 69 This is often translated as "at a time now past" (as in Marian Ury's translation) or "in olden times." ${ }^{, 70}$ Although the compiler, or compilers, are unknown, Ury points out that “...the motive was religious and behind the compilation was a very practical intention: to provide a handbook of stories which preachers might use to enliven their sermons," 71 and indeed the Konjaku is the largest collection of setsuwa tales.

\footnotetext{
${ }^{67}$ Watson, Record of Miraculous Events in Japan, 146-148.

${ }^{68}$ Ury, Tales of Times Now Past, 1. From here on referred to as Konjaku.

69 Ibid.

${ }^{70}$ Naoshi Koriyama and Bruce Allen, Japanese Tales from Times Past (North Clarendon: Tuttle Publishing, 2015), 26.

${ }^{71}$ Ury, Tales of Times Now Past, 2.
} 
Despite the lacunae within the text itself, (some sections are missing or lost ${ }^{72}$ while some information has been intentionally left out), much can be derived from the tales with which we are left. Because the Konjaku pulls inspiration from Indian, Chinese, and Japanese sources, it is not an easy task to identify which tales were from the oral tradition; this must be done through process of elimination. If a story resembles a Jataka tale, or a story from a sutra, we can deduce that it was not told orally amongst Japanese villagers. On the other hand, if a story does not have a precedent in literature from India or China, it is safe to assume that it was most likely collected from, or inspired by, an oral tradition. In other words, "motifs, incidents, or tales that do not derive from Buddhist literature can be taken as Japanese, and as part of their ancient conceptual frame-work.,"73 Another clue is in the language used in the tales. Robert Smith points out that in the tales from India, the phrases "“in a previous rebirth," "the way of merit," "the acts of devout monks," "the power of the Lotus,"” or "“"the true teaching,"” are prevalent while in the Japanese tales there is a focus on this world and ordinary people: "“"grandsons are now living," "the province was well content," "all blamed the wife," "the fortunate man.'”' In other words, "the Indian religious tales continually look before and after this life, while the Japanese tales speak of supernatural occurrences of everyday life."74 Instead of focusing on the next life, they focus on this life.

\footnotetext{
${ }^{72}$ William Ritchie Wilson, "The Way of the Bow and Arrow. The Japanese Warrior in Konjaku Monogatari,” Monumenta Nipponica 28, no. 2 (1973): 177-233. doi:10.2307/2383862.

${ }^{73}$ Robert Smith, "On Certain Tales of the "Konjaku Monogatari” as Reflections of Japanese Folk Religion,” Asian Folklore Studies 25 (1966): 221-233. doi:10.2307/1177479.

74 Ibid.
} 
Another aspect of the Konjaku that Ury stresses, though not untypical of this time, is the "magpie tendency"75 with which the stories were collected. However, this does not mean that the compilation lacks order. On the contrary, "[w]ithin each chapter the stories are meticulously arranged. As a rule, they appear in pairs joined by a common theme; in addition, each member of the pair will have associations with the other story adjacent to it through some common motif."76

The chapters are arranged as follows: "CHAPTERS ONE TO FIVE: Tales of India, beginning with the founding of Buddhism... CHAPTERS SIX TO TEN: Tales of China, beginning to the establishment of Buddhism... CHAPTERS ELEVEN TO TWENTY: Tales of Buddhism in Japan... CHAPTERS TWENTY-ONE TO THIRTY: Secular tales of Japan." The "secular" designation is a bit of a misnomer, as even the stories in these chapters it is clear that the "compiler's stance... is determinedly didactic." $" 77$

The story in which the ubume makes her first textual appearance is found in chapter twenty-seven (XXVII), "tales of malevolent supernatural creatures.” According to Kunisaki Fumimaro, "the chapters of secular tales of Japan in turn reiterate the Buddhist ones in overall arrangement," and therefore the story of the ubume, tale 43 in chapter twenty-seven, falls within "instruction... paralleling chapters 19-20." Chapters nineteen and twenty consist of "tales of religious conversion; strange tales illustrating the

\footnotetext{
${ }^{75}$ Ury, Tales of Times Now Past, 2.

${ }^{76}$ Ibid., 6.

${ }^{77}$ Ibid., 2-4.
} 
principle of karma" and "a few tales of a kind of goblin called tengu; tales of visits to hell; tales of karmic retribution in this present life, ${ }^{, 78}$ respectively.

In terms of chapter twenty-seven, it would be helpful to consider the perspectives on supernatural creatures in setsuwa collections laid out by Mori Masato that the compiler utilized.${ }^{79}$ Editorial refers to the actual collecting of the tales and the previously discussed order they were placed in, while selection refers to meaning assigned to the tales "in order to fulfill the editorial plan of the collection." Narrative, Mori explains, is "the concrete choice of words to clarify the function and meaning of each individual tale." Mori uses this structure to "to clarify the meaning assigned to supernatural creatures during the Heian period, ${ }^{~} 80$ which will be discussed now before turning to the story of an ubume. Or, rather, the story of the man who meets an ubume.

As noted in the introduction, when examining the supernatural world of yōkai, yūrei, and kami, some consistency does emerge, just as with the natural world. As Mori points out, there are three types of "rules" that supernatural creatures in the Konjaku tend to adhere to: time, location, and the more thematic "as opponents of order." ${ }^{81}$ This "order" refers to the world of humans.

Time and location are incredibly important when navigating the world of yōkai. During the Heian period, in which the Konjaku was compiled, supernatural creatures

\footnotetext{
${ }^{78}$ Ibid., 4-5.

${ }^{79}$ Masato Mori, ““'Konjaku Monogatari-shū”: Supernatural Creatures and Order,” Japanese Journal of Religious Studies 9, no. 2/3 (1982): 147, accessed June 10, 2017, http://www.jstor.org/stable/30233945.

${ }^{80}$ Ibid., $147-148$.

${ }^{81}$ Ibid., 156.
} 
were perceived as tangible threats. For example, the court employed "practitioners of Onmyōdō, a complex system of divination and geomancy based on principles of yin and yang, ${ }^{, 82}$ to determine when the hyakkiyagyo would be appearing in the capital.

Hyakkiyagyō, written in Japanese as 百鬼夜行, refers to a night procession of one hundred demons, the character for demon being 鬼, or oni. Oni are another category of supernatural entities in Japan, and during this period (pre-1185), it was used as an umbrella term for "any sort of nasty and threatening creature." 83 The key here is "night," and as Mori points out, "the reader of Volume XXVII [of Konjaku] will soon be struck by the fact that supernatural creatures are active primarily during particular set time periods... Nighttime seems indeed to have been the time period made especially for these creatures. Nighttime was clearly a special time, one exempt from order the controlled by humans during the daylight hours." 84

These creatures also "lived, or appeared, at certain fixed locations." Just as the hyakkiyagyō would be predicted to appear at a certain time at a certain place, the compiler of the Konjaku "added a detailed geographical explanation of places considered haunted...spirits controlled such locations, and it was necessary for humans to learn that they should not invade them." Interestingly, these places "frequently were bridges or

\footnotetext{
${ }^{82}$ Foster, The Book of Yōkai, 15.

${ }^{83}$ Ibid.

${ }^{84}$ Mori, “Konjaku Monogatari-shū,” 148.
} 
riverbanks, ${ }^{, 85}$ and, as we will see, the ubume appears in a river. ${ }^{86}$ They also often appear near gates, which, when considering that a gate, a bridge, or a river marks a boundary or separates one place from another, they have the same function. This also explains why these creatures can be seen as opposing order, as they occupy liminal spaces, close to but not always under the control of humans. ${ }^{87}$ In a way, the meticulous order in which the stories are compiled is a means of control, or "bringing light into the darkness of confusion and providing order." 88

Where does the ubume fit within this chaos and order? First, let us look at the story itself, which appears in the 2015 translations by Naoshi Koriyama and Bruce Allen:

Taira no Suetake, a Retainer of Yorimitsu, Comes across a Woman with a Baby ${ }^{89}$

In olden times, Minamoto no Yorimitsu was the governor of Mino Province. One time, he went off to a certain county in the province. One night, a number of samurai were gathered in their quarters, engaging in idle talk. Someone said, "I hear a certain woman has been showing up with a newborn baby at a place called Watari in this province. When someone goes across the river, the woman appears with a crying baby and requests of him, 'Hold this baby. Won't you hold this baby, please?"' Hearing this, one of the men said, "Is there anyone here brave enough to go across that river to Watari right now?" A man named Taira no Suetake replied, "I could go there even at this very moment." Some other men said, "No, you might be able to fight a thousand enemies, but you won't be able to cross that river now." But the man insisted, "It'll be nothing for me to cross that river." The others chided, "No matter how brave you may be, you'll never be able to get across that river."

${ }^{85}$ Ibid., 149-151.

${ }^{86}$ When the ubume was later depicted in Edo Kabuki plays, the playwright that most frequently invoked her image consistently placed her in or near water: Shimazaki, "Figures of the Ubume and the Breakdown of Theater Tradition," 218.

${ }^{87}$ Mori, "Konjaku Monogatari-shū," 155.

${ }^{88}$ Ibid., 163.

${ }^{89}$ Interestingly, in their translation, they do not call this woman an ubume. However, the title of the story in Japanese is 頼光郎等、平季武、值産女語, which Reider translates as "Yorimitsu no rōtō Taira no Suetake ubume ni au koto" (Yorimitsu's retainer, Taira no Suetake, meets an ubume), Reider, Seven Demon Stories from Medieval Japan (Logan: Utah State University Press, 2016), 34. 
Since Suetake had spoken so boldly, he insisted on going. About ten men argued with him and then proposed, "It's no use just arguing. Let's each of us bet something, like some armor, helmets, arrows, quivers, a saddled horse, or a sword." And so they made bets. Suetake, too, wagered, "If I can't go across that river, I'll give those things to you. Will you all swear on your bets too?" The others replied, "Of course we will! So now get going, immediately." Suetake prepared himself with armor, a helmet, and arrows in a quiver. The men asked, "How will you prove that you've made it across the river?" He replied, "I'll pull out one of the arrows from my quiver and stick it in the dirt on the other side of the river. You may go there tomorrow morning and see for yourself!" And on saying this, he left. Soon after, three feisty young men from among those who had opposed Suetake suggested, "We should go and make sure he really crosses the river." So secretly, they ran out, following after Suetake's horse. Suetake was already there.

It was a moonless night, near the end of September. They could hear Suetake wading through the river with loud splashing. Presently, he reached the other side. The three men listened, hiding in the pampas grass on the near side. Then Suetake must have quickly pulled out an arrow and struck it into the ground, for soon he seemed to be wading his way back. Straining their ears, they could hear a woman's voice calling out to him from the middle of the river. "Hold this baby," she said, "Won't you hold this baby, please?" And then they also heard the squealing voice of a baby. At that time, an awful, fishy smell drifted over the river to their side. Although the three men were together, they were terribly frightened. Just imagining the fear of the man wading across the river gave them the chills.

Then Suetake said, "All right then, let me hold it." The woman said, "Here it is," and she handed it over to him. Suetake cradled the baby in the sleeves of his robe. Then the woman came running after him, demanding, "Give me back the baby." Suetake said, "No, I'll never give it back," and he walked back up the riverbank on the near side. Then he returned to the governor's residence, with the three men running after him. He dismounted his horse, entered the house, and said to the men who had doubted him, "You said I couldn't do it, but I went to Watari and waded across the river and I've even brought the baby here." And on saying this, he opened the folds of his right sleeve. But, lo and behold, there was nothing there but a few tree leaves.

After that, the three men who had secretly followed Suetake told everyone about what they had seen at the river. Those who hadn't gone were all terribly frightened by it. Then they brought out all the things they had bet, but Suetake didn't take any of them. "I only said I would do it. Who wouldn't have been able to do such a simple thing?" And then, after saying this, he returned all the wagers.

Those who heard the story were deeply impressed and praised him. Some said that the woman with the newborn baby was a fox trying to bewitch humans, while others said that she was the ghost of a woman who had died in childbirth. Such then is the story as it has been handed down to us. ${ }^{90}$

${ }^{90}$ Koriyama and Allen, Japanese Tales from Times Past, 206-208. 
First, we should discuss the characters that are specifically named. Minamoto no Yorimitsu, ${ }^{91}$ the governor of Mino, was a historical figure, governor being "the highest official of the provincial bureaucracy... appointed from the capital." 92 Yorimitsu actually appears in multiple stories within and beyond Konjaku and is associated with another yōkai, the tsuchigumo, or earth spider. ${ }^{93}$ Taira no Suetake, his retainer, was also a living person, and accompanied Yorimitsu on perhaps what is his most famous adventure: the defeat of Shuten dōji, an oni that had been causing harm in the capital. ${ }^{94}$

What would life have been like for these men? The Konjaku "was compiled at a time of social change. In the capital, the system of aristocratic rule, which had been in its glory a hundred years earlier, was under strain, while in the provinces the military families which by the end of the century would provide the de facto rulers of Japan were gathering strength." Within this climate, Wilson points out that "the warriors of the Konjaku tales were armed men living on the land on the fringes of an expanding agricultural economy," and throughout the collection, "the general attitude toward warriors is one of admiration" 95 As mentioned, the ubume falls within chapter twentyseven. Chapter twenty-five deals exclusively with warriors, but the theme of honor is "central" to most of the tales that deal with warriors.

\footnotetext{
${ }^{91}$ Also known as Minamoto no Raikō.

${ }^{92}$ Wilson, "The Way of the Bow and Arrow," 184.

${ }^{93}$ Noriko T. Reider, "Tsuchigumo Sōshi: The Emergence of a Shape-Shifting Killer Female Spider." Asian Ethnology 72, no. 1 (2013): 55-83, accessed December 10, 2017, http://www.jstor.org/stable/41958916.

${ }^{94}$ Foster, The Book of Yōkai, 41.

${ }^{95}$ Wilson, "The Way of the Bow and Arrow," 184-189.
} 
Next, we should consider the other tales in chapter twenty-seven that deal with similar themes, characters, and locations. As mentioned, the layout of the Konjaku was painstakingly meticulous. Stories feed in to one another, characters reappear, and plots overlap. From them, we can discern attitudes that help explain the ubume.

Story 15 of chapter twenty-seven, titled "How a Woman Who Was Bearing a Child Went to South Yamashina, Encountered an Oni, and Escaped," deals with an “intelligent woman" who "found herself pregnant without a proper husband." With no one to help her, she decides to find a secluded place to give birth and abandon the child. This suggests that to have no relatives, and to become pregnant without first being married, was a source of anxiety. She was "ashamed to confess her condition," 96 and hence felt the need to hide it.

After venturing off into the woods, she comes across a secluded estate occupied by an old woman who offers to help her. Believing that the Buddha "had come to her aid," she "had an easy delivery," and decides not to abandon the baby once she sees it is a "beautiful little boy." The old woman says to her, "Old people like me who live in countrified places like this don't need to worry about taboos. Why don't you stay here for seven days, until your defilement is over," 97 suggesting that customs were already in place to separate pregnant woman due to their impurities. ${ }^{98}$

\footnotetext{
${ }^{96}$ Ury, Tales of Times Now Past, 161.

${ }^{97}$ Ibid., 162.

98 This theme is discussed at length in the next chapter. Interestingly, the last parturition hut used for childbirth "was in use until the 1950s," Hardacre, Marketing the Menacing, 24.
} 
The woman's happiness is short lived, however, as she overhears the old woman exclaim, while looking at the baby, "only a mouthful, but my how delicious!"99 The woman and the baby escape and the story concludes with, "Now think: ancient places of that sort always have supernatural beings living in them... only an oni could have looked at an infant and said that. This shows that you should never go into such places alone."100

Unlike the ubume, barring the fact that she may well have been a fox simply playing a trick, the mother in this story ultimately is able to fulfil her duties to her child. It also seems that the compiler was suggesting that to think violent thoughts towards an infant would be demonic, although the main point is to stay clear of old places. This message is explicit, while in the ubume story the actions of a character (Suetake) are the main point.

Story thirteen of chapter twenty-seven follows the construction and plot of the ubume tale, with a much more violent ending. A group of men also make a wager to test their bravery and, as with the ubume narrative, it opens with them discussing a location, in this instance a bridge, that people have been avoiding. ${ }^{101}$ The emotions of the warrior who agrees to cross the bridge are stated more explicitly. Perhaps the storyteller wished to create a sense of unease because of the grim ending. He sees a woman on the bridge but reasons it must be a demon and rides his horse right past her, which greatly angers the demon, and he is able to escape.

\footnotetext{
${ }^{99}$ Ury, Tales of Times Now Past, 162.

${ }^{100}$ Ibid., 163.

${ }^{101}$ Koriyama and Allen, Japanese Tales from Times Past, 192.
} 
However, his troubles are not over. "Sinister things began to occur at his house," and the man consulted an Omnyōji who told him to seclude himself on a specific time and day. ${ }^{102}$ He shuts himself in but when his younger brother comes knocking with news of their mother's death, the man lets him in. The wife of the man later hears the two brothers fighting and her husband demands she get his sword. However, she hesitates, not knowing the younger brother is actually the demon, and in that instant he bites off the head of the older brother. A cautionary summation after this grisly scene states, "and so we can see what happens when a woman interferes and tries to act too clever."103

\section{Summary}

In the Konjaku the ubume is used as a terrifying female figure in opposition to warrior (male) order. She is associated with a specific location, typical of the supernatural in setsuwa. However, there is a stronger focus on the men who encounter her. In this instance, a warrior bravely seeks out the spot she is known to haunt and comes away unscathed. Despite the fact that the emphasis is on Suetake's bravery and honorable act of refusing to take the wagers he won, this text indicates that it was already known that should a woman die while pregnant, she could potentially become an ubume, although perhaps not viewed as quite a grave a sin as it would later come to be.

If this story was used to enliven sermons, then we can infer that monks were promulgating the notion that to die during childbirth would lead to the horrible fate of becoming an ubume into a society that had already absorbed the idea of karmic

\footnotetext{
${ }^{102}$ Ibid., 193.

${ }^{103}$ Ibid., 194.
} 
retribution and the defilement of blood and fear of the dangers the improper care for a dead mother and infant posed, whether the baby survived or also perished. If the story was also meant to be an attempt to bring order to the supernatural world so prominent in the Heian period, it would seem to both warn of the Watari area but also imply that if one is brave, and honorable, one can escape an encounter with an ubume.

In either case, the ubume here is meant to be foreboding. Later we will see how visual representations turned her into a more pathetic and sorrowful figure. However, her figure is used here to bolster the legends surrounding two historical figures, Yorimitsu and Suetake. 


\section{RELIGIOUS RAMIFICATIONS}

Why is the ubume still a part of the yōkai pantheon, nearly 1,000 years after she was mentioned in the Konjaku? What occurred within the spiritual landscape of Japan that led to the development, and importance of, rituals related to death in pregnancy, such as "mifutatsu," ("the custom of fetus removal before burial,") 104 as the villagers of the 1950s incident opted for? As we will see in the next chapter, their persistence is partly explained by, and accounts for, the ubume's prominence in the arts of the Tokugawa period. But how did a ghostly figure mentioned in a tale exalting the bravery and selflessness of a warrior become so popular that multiple religious customs were developed and deployed to avoid becoming one? Why did artists invoke such an image so often? The introduction of the Ketsubonkyō sutra from China during the Muromachi period (1336-1573) was one of the main reasons the ubume was not lost to history with countless other figures of folklore not solidified in yōkai culture who vanished into obscurity.

Repetition is the key to a legend's or belief's success and in the case of the ubume, the religious practices and ramifications discussed below had immense impact on her developments and were indeed prominent in the everyday lives of people, regardless of class or gender. As Iwasaka and Toelken point out, “...if the same themes, anxieties, concerns, and values found in a group of legends are also prominently displayed in the daily lives of the people who tell them... these legends offer one of the best possibilities for insight into an ongoing culture." ${ }^{105}$ Literature such as setsuwa and visuals such as

\footnotetext{
104 Yasui, "Research Notes,” 104.

${ }^{105}$ Iwasaka and Toelken, Ghosts and the Japanese, 45.
} 
woodblock prints helped spread these ideas and beliefs, ensuring their place in Japanese culture. The religious atmosphere, beginning mainly in the late Heian period, both condemned women and gave them opportunities for spiritual liberation. Legends featuring figures like the ubume developed to give narrative form to these contradictions. ${ }^{106}$

\section{Indigenous Ideals}

As noted in the introduction, purity and impurity govern the Shintō tradition. There is a balance to everything and a ritual for everything. Impurities can be considered taboos, the two most defiling being death and blood. As such, Shintō is understood most usefully as a multitude of rituals concerning life. Misfortune would result from committing a taboo and not performing the ritual to restore purity, not entirely unlike the Buddhist notion of karma. This malady would come in the form of tatari, which originally referred to the wrath of kami when they became polluted with impurities. Tatari could come in the form of illness, death, or even the fall of a powerful household.

The word Shintō, written with the ideographs 神道, "kami” and "road," is often translated as the "way of the kami." Kami, which are generally thought of as deities, can also refer to spirits of the dead, and in pre-Buddhist Japan they intermingled with the living just as much as their more deified counterparts. ${ }^{107}$ However, Shintō was primarily concerned with the balance of the purity and impurity in life, mostly avoiding death due to its impurity. Thus, Buddhism became more dominant in the handling of the dead.

\footnotetext{
106 Ibid., 8.

${ }^{107}$ Kasulis, Shinto, 76-77.
} 
Much of what we know about the attitudes espoused within Shintō comes from the aforementioned Kojiki and Nihon Shoki, which contain a multitude of tales chronicling kami as well as emperors.

Within these tales, the primordial kami couple, Izanami and Izanagi, form the foundation for articulations of Shintō metaphysics. Hardacre points out that:

"within this relation of gender complementarity, the male should take the initiative, and the female should yield and assent. When those conditions are met, their union is successful, but when the female usurps the male prerogatives, deformities or incomplete creations are the result. This construction assumes that the female is incomplete without the male, and that female initiative lacking male guidance is doomed to failure." 108

In other words, this story lays out the ideal male/female relationship dynamic. Again, it should be stressed that the mythologies contained in these works do not necessarily reflect the beliefs and actions of the people living at the time of their compilation. However, in them we can see the seeds of the patriarchy to which eventually the ubume become such a threat to as the inverse of what an ideal woman should be: a mother. Another example of this that Hardacre explores in terms of the "public" and "private" spheres of the state and its people is the story of Powori and Toyotamahime. In this myth, a female kami "either gives birth in fire to prove he [the male kami] is the father, or... reverts to a bestial form to give birth, making a partition hut to hide herself from view and charging her husband not to look inside under any circumstances. It goes without saying that the male Kami can never resist the temptation to look. After giving birth, she leaves the child with the husband and withdraws." 109 While this story is not

\footnotetext{
${ }^{108}$ Hardacre, Shinto, 52.

${ }^{109}$ Ibid., 62-63.
} 
concerned with death in pregnancy, it does echo the fate of Izanami. In both instances, the male kami, threatened by his female counterpart subverting his authority (in the former case, her speaking before him and in the latter, her possibly producing a child that is not his), comes away relatively unscathed while the female is not so lucky. In the seventh century, "while some women remained with her natal family after the marriage... the children of these marriages were generally raised by the mother, but they were also claimed by the husband's kin, creating a bilateral tendency in the system of kinship." "110 Despite the fact that in both narratives the male transgression of looking upon something he not supposed to (Izanami in the world of the dead, Toyotamahime giving birth), it is the female that must pay for his mistake.

By the eighth century, "higher levels of society were already beginning to change. We can see the beginnings of patriarchalism that would eventually result in the ejection of women from the public sphere and from state ritual." Previously, men and women would have multiple marriage partners but when succession became vital to the imperial line, so too did the legitimacy of the children. When those in authority were challenged, in the stories mentioned, the women causing the issues conveniently died, or withdrew. Much like the dichotomy of order/chaos, "in all cases, the male is associated with the public and the female with the private. The public-private dichotomy conveys a conception of gender in which the feminine is lesser and the female must renounce her

\footnotetext{
110 Ibid.
} 
children and her kin's claims in favor of the higher good represented by the male and the public." 111

In short, the Kojiki and particularly the Nihon Shoki were compiled with very political objectives. As Hardacre points out, "we can regard the myths... as exploring the

dynamic between the public and the private through narratives about the Kami." 112 And if we consider that during this time society was set to model the behaviors and desires of the elites, we can deduce that the attitudes toward women in the stories did not remain the concerns of only the upper-class. However, despite the impurities associated with blood, it was not until the late Heian period, when Buddhism had spread beyond the aristocracy to the laity as well, that this became especially condemning for women. What we can see from pre-Heian period texts and historical developments is that as various lineages vied for power, women were further and further removed from the power they once held as daughters (such as rights related to inheritance) and placed in a more private role of wife and mother.

\section{Buddhist Influence}

While women enjoyed a relatively equal standing with men in the Buddhism of preHeian period (794-1185), which mostly elided the physiological difference between them, the groundwork for more misogynistic attitudes had already been laid. For example, the Lotus Sutra, even before the inclusion of the Dragon Girl story, discussed

\footnotetext{
${ }^{111}$ Ibid., 64.

${ }^{112}$ Ibid., 64.
} 
below, insinuated that, "the ideal practitioner was assumed to be male."113 The Taihō Code, written in 701, also paved the way for the state to firmly control Buddhism, and in order to do this, "the state sought a specialist in the Buddhist precepts who could also establish an official Buddhist ordination platform." With this, ordination came to require that "monks observe 250 precepts, while nuns had to observe 348 precepts." 114 The subsequent Yōrō Code, which focused legislation against practicing outside of the state sponsored institutions, and the Engishiki, another book of laws, made it difficult for the previously powerful female shamans to continue and placed them in subordinate positions within "the official shrine system.",

During the Heian period, historically, women were still "engaged in devotional practices as nuns, pilgrims, and patrons," but "marriage and inheritance patterns shaped women's religious choices and opportunities." In short, husbands and sons, held more power than wives and daughters, and attitudes towards the female body, exemplified by the Heian period literature, suggest that the laws in place to protect women from offenses such as rape were geared more towards assuring "patrilineal authority" and not so much to protect women. ${ }^{116}$

While individuals were becoming increasingly concerned with their afterlife, living women were being excluded from certain religious spaces, such as the Shingon

\footnotetext{
${ }^{113}$ Ambros, Women in Japanese Religions, 47.

${ }^{114}$ Deal and Ruppert, A Cultural History of Japanese Buddhism, 65.

${ }^{115}$ Ambros, Women in Japanese Religions, 63.

116 Ibid., 56-59.
} 
sect's Kōyasan, the monastic center of Shingon, and the Tendai sect's Hieizan, the monastic center for the Tendai sect. At the same time, "belief in blood pollution (through menstruation and childbirth) slowly began to gain currency among nobility and in monastic circles alongside the Confucian concept of women's Three Obediences and the Buddhist notion of women's Five Obstructions. Given the proliferation of such beliefs, the notion that women were innately flawed and sinful spread." 117

Setsuwa were one way in which the laity came to be familiar with such ideologies, and during the Heian period visuals to accompany setsuwa, or even used in place of them, developed. Etoki, written as 絵解き, the characters denoting picture and understanding, carried with it the same soteriological aim as setsuwa. They were used in much the same way, and the term has been translated as "preaching with pictures."118 Hell scrolls, or scrolls depicting the ferociously detailed Buddhist hells, were often used as teaching tools. They provided a visual for what one was destined for the in the afterlife. In the case of women, this was the Blood Pool Hell. Women eventually took on a very active role in spreading these ideas, an example of how this notion of female inferiority led to their condemnation but also encouraged them to take their fate in the afterlife into their own hands.

Before turning to this gruesome hell reserved for women, it is helpful to note the historical developments of medieval Japan, which lasted from about 1185-1600, and their influence on religious attitudes and fears. In brief, this was a time of widespread

\footnotetext{
${ }^{117}$ Ibid., 66-69.

${ }^{118}$ Ibid., 99.
} 
violence and precarious military rule. Because various families were competing for power at the expensive of their lives, patrilineal lineage because increasingly important. "This new system," Ambros writes, "constructed women's bodies as a means to produce offspring for the patriarchal lineage of the husband's household." ${ }^{119}$ This meant that women came to be seen in regards to their role as mothers, further strengthening the patriarchal ideals already in place.

At the same time, perhaps not surprisingly given the violence that characterized this period of Japanese history, Pure Land Buddhism, which offered a means to salvation by merely invoking the name of Amida Buddha, ${ }^{120}$ spread in popularity. The idea of the decline in the Dharma, or mappō, was still prevalent and for many the only means to salvation came in the form of being reborn into Amida Buddha's Pure Land. However, the notion that in order for a woman to be reborn in this paradise she had to first transform into a man enforces the notions of male spiritual superiority. This idea was still upheld by many. This does not mean, however, that women became less involved in Buddhism. On the contrary, with their fathers, husbands, and sons dying in the brutal struggle for leadership, women became more involved in monastic life. Convents were formed specifically for women that chose not to remarry. ${ }^{121}$

It was also during this time that the Devadatta chapter of the Lotus Sutra containing the chapter about the Dragon King's daughter achieving Buddhahood by

\footnotetext{
${ }^{119}$ Ibid., 79.

${ }^{120}$ Deal and Ruppert, A Cultural History of Japanese Buddhism, 92-93.

${ }^{121}$ Ambros, Women in Japanese Religions, 85.
} 
transforming into a man received more attention. This story became a primary message of monks during the Heian period, who disseminated it beyond the elites. The notion of females only attaining Buddhahood as males was not limited to the Tendai sect, however, and later Pure Land Buddhism also promulgated the belief that in death, women would be reborn into the Pure Land as men. Tendai, along with Shingon, was one of the new lineages of Buddhism that formed in the early Heian period. While there were divergences in these "new" sects, they still shared similarities with one another. ${ }^{122}$ Despite the fact that there were accounts of laywomen staying women after death, such as coming to others in dreams, "family members remained deeply concerned with the posthumous well-being of their female relatives." 123 This involved the copying of sutras which was immensely important with the rise in popularity of the Ketsubonkyō, a sutra directly linked with women's salvation.

As with the contradictory nature in which the female body was viewed in the literary works discussed, the monastic community viewed women with equal ambivalence. The patriarchal hegemonic forces behind the monastic community had to grapple with more and more women engaging in it and with this trend, "concepts of female pollution and karmic hindrances" spread further amongst the laity. ${ }^{124}$ For example, Hōnen (1133-1212), who was seen as “inaugurator of Japan’s Pure Land

\footnotetext{
${ }^{122}$ Deal and Ruppert, A Cultural History of Japanese Buddhism, 69-70.

${ }^{123}$ Ambros, Women in Japanese Religions, 66-69.

${ }^{124}$ Ibid.
} 
lineages," 125 addressed directly the issue of a women dying during pregnancy: "with the chanting of the nenbutsu, she will achieve birth in the Pure Land." This indicates that the idea that "women who die in childbirth are a special category of dead and are particularly difficult to save" was prevalent enough to address. ${ }^{126}$ While the Konjaku story of the ubume ends with the ambiguous conclusion that the spirit encountered was either the ghost of a woman who died during pregnancy or was a fox playing a trick, we can infer that not all instances could be written off as simply as the mischief of foxes.

It was in this sort of environment that women had to navigate their place in society as well as their place in the afterlife. They were supposed to produce children, as mothers, but it was this very identity that came to be condemned and associated with a fate perhaps more gruesome than that of their husbands' bloody death in battle.

\section{The Ketsubonkyō}

During the late Muromachi period (1336-1573), ${ }^{127}$ a sutra called the Xuepen jing was transmitted to Japan from China, called Ketsubonkyō (血盆経, Blood Bowl sutra) in Japan. In what Duncan Ryūken Williams calls "one of the most striking examples of priestly

\footnotetext{
${ }^{125}$ Deal and Ruppert, A Cultural History of Japanese Buddhism, 117.

${ }^{126}$ Glassman, “At the Crossroads of Birth and Death,” 179.

${ }^{127}$ The dating and origins of the sutras in Japan are still debated but Takemi Momoko reasons that "a version... that was discovered at Gunma Prefecture can be shown to be earlier than late Muromachi. A woodblock manuscript discovered in a roof at Gangōji has been dated between the mid and late Muromachi period. All other manuscripts known now are from the Edo period, so current knowledge would place the sutra's first presence in Japan at about the middle Muromachi period" (Momoko Takemi, “"Menstruation Sutra" Belief in Japan," Japanese Journal of Religious Studies 10, no. 2/3 (1983): 238, accessed March 10, 2017, http://www.jstor.org/stable/30233304).
} 
mediation and interventions on behalf of its parishioners in the afterlife" 128 the sutra spread across sects and promulgated the belief that blood shed during childbirth and/or, depending on the version, menstrual blood, would result in women falling into the Blood Pool Hell, or the chi no ike jigoku (血の池地獄).

Takemi Momoko, who has identified 16 versions of the sutra in Japan, points out the "belief that a woman who died in childbirth would be condemned to Hell has been present in Japan for quite some time...in Nihon ryoiki...a woman who died in labor before the birth of her child went to Hell." ${ }^{129}$ From this, we can infer that "the motherly body here... is posited as an ideal site for the administration of female karmic retribution. ${ }^{130}$ In that particular example and many others, the husband of the woman must atone for her, so the responsibility falls on the family. It is not only the women that suffer but also those she leaves behind. This is a particularly unnerving thought when we consider that "[f]or the Japanese... one of the most persistent arenas of cultural concern through the ages has been death and its impact on everyday life."131

In Williams' work The Other Side of Zen, he provides a passage from a 1730 temple document describing the Blood Pool Hell:
"Once one has been born as a woman, whether one is a daughter of an aristocratic or daimyo family, no woman can escape this hell. This is because all women have the pollution of menstrual blood or the impure blood of childbirth. This blood defiles not only the earth and water deities, but all Buddhas and kami. For this, a woman falls into the hell of immeasurable suffering after death. The sufferings in this hell include, first of all, the six times a day we come out of the pool to drink blood. If we refuse to drink it

\footnotetext{
${ }^{128}$ Duncan Ryūken Williams, The Other Side of Zen: A Social History of Sōtō Zen Buddhism in Tokugawa Japan (Princeton: Princeton University Press, 2005), 50.

129 Takemi, ““Menstruation Sutra" Belief in Japan,” 238.

${ }^{130}$ Dumas, "Historicizing Japan's Abject Femininity," 263.

${ }^{131}$ Michiko Iwasaka, Ghosts and the Japanese, xviii.
} 
because of its horridness, frightening demons come and torture us with metal rods before we get thrown back into the blood pool, screaming to no avail. In the blood pool, countless insectlike creatures with metal snouts come to pierce our skin and worm into our flesh to suck our blood, before grinding into the bone to feast on the marrow. There are no words that could describe this pain. However, at times, large five-colored lotus flowers appear from within the blood pool saving some woman or another. Seeing them, one gets envious. Those are women who fell into hell but, because of the merit accrued through their good acts in their previous life, were able to escape the torments of hell quickly. Others were able to attain release and go to heaven because their descendants performed ceremonies for the Buddhas and made offerings to the Buddhist priesthood. Oh abbot, I beg you for your great compassion and that you save me from the sufferings of this Blood Pool Hell."132

This passage contains reference to both blood shed during childbirth and menstruation and synthesizes many of the earlier examples that Takemi has found. The actual sutra, the themes of which were not without precedent in Japan, tells the story of Mokuren, a disciple of the Buddha. ${ }^{133}$ The details in the various extant copies vary but the basic structure is relatively the same: Mokuren sees, or travels, to the Blood Pool Hell and seeks to save the women from this fate. In one version, the Buddha replies, "it would be necessary for them to respect the three treasures of filial piety, to call on Mokuren, to hold a Blood Pool Liberation service, to hold a Blood Pool Feast, to read sutras, to have an esoteric ceremony, then to make a boat and float it off. At that time a five-colored lotus flower would appear in the middle of the Blood Pond. Then... all of the women sinner would be saved, and reborn in the Buddha's land."134 From this and the other versions of the sutra, it is clear that all women will inevitably end up in the Blood Pool

\footnotetext{
${ }^{132}$ Williams, The Other Side of Zen, 126-127.

${ }^{133}$ In the original story of Mokuren he is saving his mother from a different karmic rebirth, that of the hungry ghosts (Glassman, "At the Crossroads of Birth and Death," 176). Not as horrific as hell but certainly not desirable, either. There are also stories in the Nihon ryoiki that feature a family member coming back as an animal for a wrong doing in their human life and seeking the assistance of a living relative to help them escape this fate. (See story 10 of Volume 1 and story 15 in Volume II in Watson's translation).

134 Takemi, ““"Menstruation Sutra” Belief in Japan,” 233.
} 
Hell, although Glassman notes that death as a result of pregnancy or childbirth "remained the most famous and indisputable cause." ${ }^{135}$ And although it is not mentioned in such non-secular texts, should she die during childbirth or pregnancy, the alternative would be becoming an ubume.

Shōsenji (正泉寺), originally called Hoshoji, is a Sōtō Zen temple thought to be the "point of origin" 136 for the sutras popularity in Japan. It was founded for Hosho-ni, the daughter of a regent for the Shogunate, supposedly in 1263. According to a gazetteer published by the temple:

"130 years after the death of Hosho-ni, the 13 year-old daughter of one of Hoshoji's parishioners fell ill. Not even doctors could cure her and so the Head Priest of Hoshoji was sent for. When he arrived, the girl told him that she had been visited by the spirit of Hosho-ni. It seemed that at the time of her death, Hosho-ni had not yet accumulated enough merit to offset the fault of living in luxury when she was a princess. Due to her lack of purity, she had fallen in the Blood Pool Hell, there to suffer endless torture. Hearing this, the priest returned to the temple and began to pray... That night an aged monk appeared in the priest's dream and told him he would receive the Ketsubon sutra that was enshrined in the world of the heavenly dragons. At sunrise the next day...he found the sutra scroll. After taking the sutra back to the temple, he copied it 1000 times and recited it every day for 7 days. After 7 days, Hosho-ni appeared to him in a dream. Due to the accumulation of merit from the recitation and copying of the sutra, she had been released from hell into nirvana. And the parishioner's daughter soon recovered. After investigating the truth of this miracle, the then Shogun Ashikaga Yoshimitsu gave the temple a framed tablet... and renamed the temple "Great Dragon Mountain Shosenji" and the village "Ichibu.",

The temple is located in Abiko, a city in present day Chiba Prefecture. Easily accessible from Tokyo, the extensive temple grounds are now surrounded by a suburb of family homes and elementary schools. The large compound is pictured below in Figure 3.1.

\footnotetext{
${ }^{135}$ Glassman, "At the Crossroads of Birth and Death," 185.

136 Takemi, ““"Menstruation Sutra” Belief in Japan,” 239.
} 


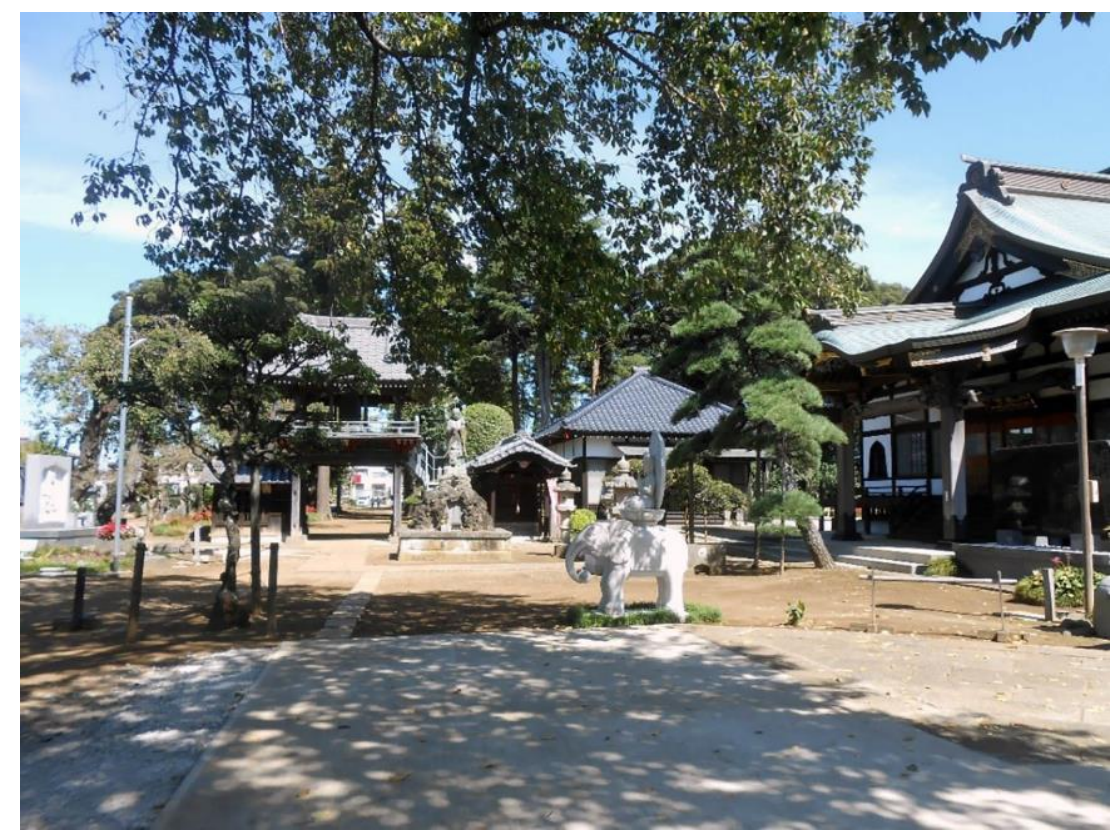

Figure 3.1: Just inside the main entrance of Shōsenji. Courtesy of the author.

In the 1970's, the temple stopped giving out copies of the sutra, and the temple actually gave their copy of what is said to be the original sutra to another temple, Zenkōji (善光寺), located in Nagano, which was also a major site for the spread of Ketsubonkyō belief. ${ }^{137}$ Regardless of this and whether or not this temple was indeed the origin for the sutra in Japan, it has a rich history related to the Ketsubonkyō and the salvation of women, evidenced by the explanatory plaque pictured in Figure 3.2. Emphasizing the talismanic function of the sutra, "priests cast the Ketsubon kyo [sic] into ponds within the temple grounds said to represent the blood pool hell or floated it off in nearby rovers to assure women's postmortem salvation." 138

\footnotetext{
${ }^{137}$ Jacqueline I. Stone and Mariko Namba Walter, Death and the Afterlife in Japanese Buddhism (Honolulu: University of Hawaii Press, 2008), 12.

${ }^{138}$ D. Max Moerman, “A Woman's Place,” in Localizing Paradise: Kumano Pilgrimage and the Religious Landscape of Premodern Japan, 228. Cambridge (Massachusetts); London: Harvard University Asia Center, 2005, accessed July 10, 2017, http://www.jstor.org/stable/ j.cttltg5mth.10.
} 


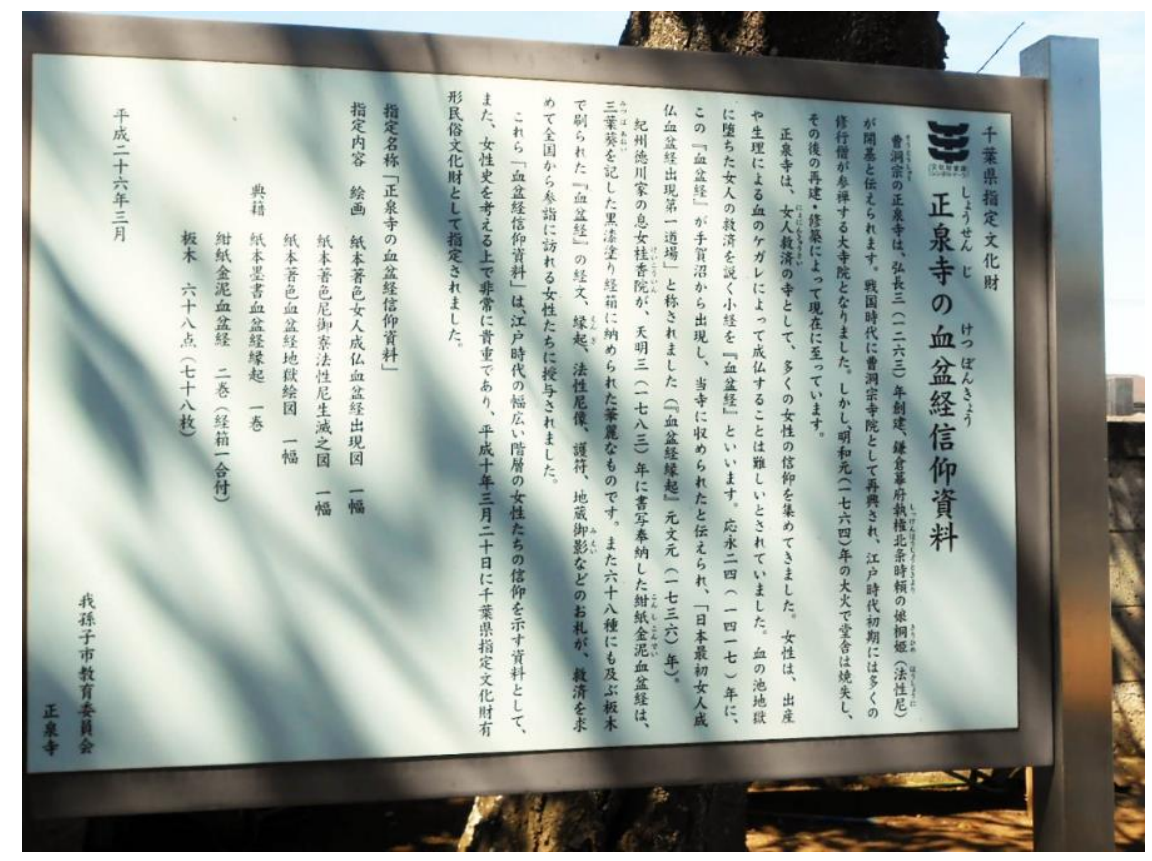

Figure 3.2: A sign displayed at the temple explaining the Ketsubonkyō. Courtesy of the author.

Williams addresses this temple, and its connection to the Ketsubonkyō, in his work on funerary Zen. He adds that Hosho-ni explained how to use the sutra: "in this world, a woman should keep the sutra on her body as a protective amulet, and when she dies, she should have the sutra buried in the grave with her." Hosho-ni also stressed the importance of Jizō, and indeed the monk that appears in the priests dream was Jizō. ${ }^{139}$ Why did the monastic community take on such a large role in the salvation of women? If we grant that any hegemonic system asserts control by convincing those under them that it is in their best interest to adhere to whatever is imposed, we can better

\footnotetext{
${ }^{139}$ Williams, The Other Side of Zen, 209. Jizō is the Japanese name of the Sanskrit Ksitigarbha. He is a Bodhisattva associated with hell and his ability to save those suffering from it. Today he is particularly associated with the salvation and protection of children (Mark Schumacher, "Jizō Bosatsu (Japanese) Ksitigarbha Bodhisattva (Sanskrit)," Onmark Productions, accessed December 10, 2017, http://www.on markproductions.com/html /jizo1.shtml.) For more on Jizō and his connection to maternity and children, see William R. LaFleur, Liquid Life: Abortion and Buddhism in Japan (Princeton: Princeton University Press 1992).
} 
understand the multitude of practices that developed for the salvation of women. In this case, Buddhism was inextricably linked with those in power and held immense ideological control. Buddhist institutions condemned women as they simultaneously offered a means of escaping that condemnation. Because the notions of tatari and the belief that the unhappy dead would, and could, cause very real problems for the living, it was in the best interest of everyone to avoid figures like the ubume. In the case of the Ketsubonkyō, three primary means of utilizing the sutra developed: as a memorial means of "saving the souls of the dead," as a means of "rebirth in the Western Paradise," and the talismanic function like the one practiced at Shōsenji mentioned above. ${ }^{140}$

The memorial function is not unlike the practice of copying sutras for the dead that developed much earlier, such as the case of the man saving his condemned wife by copying the Lotus Sutra found in the Nihon ryōiki. In a very broad sense, since Shintō developed within the context of rituals and practices related to life, and Buddhism developed by meeting the needs of the dead (or the needs of the living with concerns for the dead), copying sutras was one such way to meet those needs. Stories of the efficacy of sutras can be found in the Nihon Ryoiki, with emphasis put on the Lotus Sutra. With the spreading of this sort of spiritual remedy, along with the hell scrolls depicting the unpleasant spaces where loved ones had supposedly ended up, we can see how readily individuals would have adopted this practice.

To explore the Ketsubonkyō as a means of rebirth in Western Paradise it is instructive to turn to Tateyama, a mountain associated with Amida Buddha, in Toyama

\footnotetext{
140 Takemi, ““'Menstruation Sutra" Belief in Japan,” 240.
} 
(about four hours by train from Tokyo). At Tateyama, a practice developed starting in the Tokugawa period that allowed women to participate in the spiritual power of the mountain called Nunohashi Kanjōe, or "Cloth-Bridge Consecration [Initiation] rite."141 Similar factors that contributed to the proliferation of yōkai and yūrei in prints and books, such as political stability, also contributed to popularity of travel during the Tokugawa period and Tateyama became a popular destination.

However, Tateyama, until 1869, was considered a nyonin kinsei (女人禁制), “an area restricted for women," like the aforementioned Kōyasan and Hieizan. With more and more women partaking in travel, the Ashikuraji community that developed near the mountain capitalized on this by offering them a means by which they could also gain from Tateyama's spiritual benefits and "secure a promise of rebirth in the Pure Land." The Nunohashi Kanjōe allowed them to "tie a karmic knot" with Amida. On Tateyama, there is a red pond that acts as a symbolic Blood Pool hell, into which not only priests but male relatives as well would throw the sutra in hopes of saving women from their fate. ${ }^{142}$

Not surprisingly, the sutra began to be used by women during their lifetimes to take preventive measures into their own hands. This was one way for them to control their spirituality and their afterlife. For example, at Shōsenji, to ensure a safe delivery, pregnant women could "receive a "Ketsubon kyō" charm, which she would place inside the waistband worn by pregnant women, keeping it close to her body." After giving birth,

\footnotetext{
${ }^{141}$ Irit Averbuch, "Discourses of the Reappearing: The Reenactment of the "Cloth-Bridge Consecration Rite" at Mt. Tateyama," Japanese Journal of Religious Studies 38, no. 1 (2011): 1-54, accessed December 12, 2017, http://www.jstor.org/stable/41229968.

${ }^{142}$ Ibid., 8-13.
} 
the woman would then cut characters out of the sutra representing the Bodhisattva Jizō and drink them with water for seven nights. She then would return the remaining pieces of the sutra back to the temple and from them "receive a new copy of the sutra, which she would keep close to her body until her health had completely returned." 143 This indicates that the relationship between the woman and the temple was continuous and did not entail just a one-time visit, perhaps not unusual given that more women had turned to Buddhism in the years preceding the sutra's introduction to Japan.

\section{Mifutatsu and Nagare kanjō}

What else could be done for a woman who died during pregnancy or childbirth? Was copying a sutra or throwing it into a symbolic blood pool hell enough? Perhaps due to the threat of the ubume or kosodate yūrei, figures which, as noted, could interact with anyone and not just their living relatives, other practices developed to ensure their salvation as well as the safety of the community.

While a custom similar to mifutatsu (fetus removal) was mentioned in a Chinese source from the fifth century, "one of the oldest descriptions of this custom in Japan is found in a story called Kōya monogatari, in the medieval Otogizōshi collection of stories recorded during the fourteenth and sixteenth centuries." This story depicts the ghost of a murdered pregnant woman appearing to a priest, requesting that he "send a message to her former husband, explaining that she has not been able to achieve salvation because she was pregnant at the time of her death. After receiving this message from the priest, the husband digs the dead body out of the tomb, cuts open the belly, and removes a male

\footnotetext{
143 Takemi, ““Menstruation Sutra” Belief in Japan,” 243.
} 
baby. The moral of the story suggests that to die while pregnant was viewed as a great $\sin$ and that it was believed that removing the unborn fetus from a deceased woman's body would help her achieve salvation." 144

By the "beginning of the seventeenth century at the latest," Manami Yasui posits, "customs such as fetus removal...were found throughout the country." 145 Glassman also notes the findings of Katsurai Kazuo, a folklorist who did fieldwork in Shikoku in the 1970s. He was intrigued when he discovered there a taboo "against using oak to make the handle of a hand scythe (kama)," and learned that this was actually common in places throughout Japan for "universally the same reason. Namely, an oak-handled kama was to be used for one purpose and for that purpose alone - extracting the fetus from the body of a woman who had died in late pregnancy."146

Interestingly, in the story mentioned above, it does not tell whether or not the baby boy survived. This is where the narrative of the kosodate yūrei takes precedence and shows why the removal of the fetus was essential for the woman to gain peace in the afterlife. As Glassman notes, "there exists quite a large body of legends in which a child is discovered living underground in its mother's grave." ${ }^{" 147}$ While this maternal ghost is rather harmless (unless you are the shopkeeper she has been buying candy from), she was still viewed as an unhappy spirit and one reason for her to appear is that she has been

\footnotetext{
${ }^{144}$ Yasui, "Research Notes," 105.

${ }^{145}$ Ibid.

${ }^{146}$ Glassman, "At the Crossroads of Birth and Death,” 195.

${ }^{147}$ Ibid., 193.
} 
using the money placed in her coffin to purchase food for her baby. This money was meant to pay for the trip the deceased were thought to take across a river that separated the world of the living from the world of the dead. ${ }^{148}$ While this differs slightly from other kosodate yūrei stories, in which they steal temple offerings or pay for the food with leaves or dirt, the uneasiness that this apparition causes is still the same. She is an unhappy ghost and unless measures were taken to save her and others from this fate, they would never achieve salvation (and would presumably continue to cause problems for the living).

During the Tokugawa period, the Sōtō sect of Japanese Zen Buddhism in particular came to the forefront in promulgating the stories of the ubume and kosodate yūrei, and "through such stories, Sōtō priests encouraged people to choose Sōtō funeral ceremonies over the ceremonies of rival Buddhist groups." 149 Before their intervention, it was the job of the husband to remove the fetus from the woman. Perhaps because "pregnancy and childbirth were extensively ritualized" during this time period, even in terms of pregnancies that went smoothly, it is not surprising that religious institutions took over the role of mifutatsu to replace it with beppuku, or a "symbolic separation of the fetus from the womb." This process entailed "the officiating priest to kick the corpse, as it (the corpse) was given the tonsure and as the names of ten Buddhas were spoken into its left ear...Amulets warding off misfortune were laid in the coffin to ensure further

\footnotetext{
148 Ibid.

149 Yasui, "Research Notes,” 107.
} 
that the woman would not return as a ghost." ${ }^{\prime 50}$ From these precautions, we can infer that care for this specific death on the part of the living was immensely important, not only to ensure the salvation of a loved one but to prevent them from returning as an unhappy spirit. It seems that for some, taking preventive measures for only one of those gruesome fates was not enough to alleviate their anxieties.

Unlike mifutatsu, the nagare kanjō practice did not necessarily only involve the family of the deceased. In fact, complete strangers could partake. However, the aim of allowing the woman to achieve salvation was the same. Written as 流灌頂, the term literally means "flowing anointment" or "flowing consecration," or as Hardacre refers to it, "flowing funeral." 151 The "most common" variation of the ritual consisted of "the suspension of a cloth from two or four poles above a river or along a roadside. This cloth was dyed red (in some cases it was an actual piece of blood-stained clothing or bedding from the birth itself)..."152 Those who came across the cloth would pour water over it until eventually the red color faded. Theobald A. Purcell describes the scene in his "Our neighborhood", or, Sketches in the suburbs of Yedo: "a passer-by ladling a measure of water upon the linen, and waiting with some shew of reverence, until the fluid had passed through before resuming his journey." 153

\footnotetext{
${ }^{150}$ Hardacre, Marketing the Menacing Fetus, 22-27.

${ }^{151}$ Ibid., 26.

${ }^{152}$ Glassman, "At the Crossroads of Birth and Death,” 185-186.

153 Theobald A. Purcell, "Our neighborhood", or, Sketches in the suburbs of Yedo (Yokohama, 1874), 59.
} 
It is important to note the changing conceptions and attitudes towards the fetus that were developing in the sixteenth and seventeenth centuries. During this time, the fetus came to be regarded as separate from the mother. The end of the Tokugawa period and the beginning of the Meiji period (1868-1912) saw immense social and political change that naturally affected the family. Not unlike other countries of this time, "laws outlawing both infanticide and abortion were promulgated and enforced," and increasing the population came to be seen as the duty of the "patriotic duty" of women. ${ }^{154}$ We can see that with the practice of beppuku, the priests were focusing on the mother rather than the fetus. Hardacre points out that initially, "the hope for the fetus was merely that it be reborn, not, like the mother, that it attain Buddhahood." 155

\section{Summary}

This chapter focused on the religious ideologies and repercussions for women, and showed that "in medieval Japanese Buddhism, the salvation of women increasingly came to be understood as the salvation of mothers." ${ }^{156}$ It also emphasized the historical trends that put increasing focus on patrilineal family lines, leading to the solidification of the ideology of motherhood, or the notion that women were defined by their roles as mothers. It was also this role that condemned them, as the Ketsubonkyō sutra spread across sects and classes, promulgating the notion that blood shed during childbirth and menstrual blood resulted in a woman's karmic rebirth in the Blood Pool Hell.

\footnotetext{
${ }^{154}$ LaFleur, Liquid Life, 120-121.

${ }^{155}$ Hardacre, Marketing the Menacing Fetus, 27.

${ }^{156}$ Glassman, “At the Crossroads of Birth and Death,” 175.
} 
Religious spaces that are connected to the ubume and kosodate yūrei in contemporary Japan are discussed in the last chapter. While belief in Buddhist hells and tsumi are not as readily associated with gender in the modern day, the conflation of woman with mother is, as well as the stigmatization of non-reproduction. This has led to the continued popularity of temples and shrines related to maternal concerns such as safe childbirth and abundant milk, which have taken the place of practices like mifutatsu and the nagare kanjō. Concerns surrounding reproduction and the family in a low-birthing and aging society have taken the place of concerns surrounding the afterlife, although the world of the living is still never far from the world of the dead. 


\section{TOKUGAWA TERRORS}

After a period of Japanese history categorized by chaos, war, and violence, the Tokugawa government established a period of relative peace that allowed for the flourishing of cultural arts on an unprecedented scale. This period, which lasted from 1603 to 1868 , introduced the visuals for many yōkai and yūrei that are still referred to today by artists, including the visual of the ubume. Despite the rigid social order which aided in keeping the peace, "one of the intersections between the high and low was a taste for the weird," 157 and indeed it seems that regardless of class, people enjoyed anything and everything to do with yōkai. More and more people could read and write, and this was also a time when "Chinese influence rose to a peak," ${ }^{158}$ inspiring Neo-Confucian schools of thought.

At the same time, anxieties surrounding pregnancy and childbirth were still prevalent, as was the preoccupation with proper care for the dead. As information was able to spread more quickly with improved means of communication, and travel, so too did the notions of the Blood Pool Hell and the fear of the ubume. The visuals explored below "provide us with immediately visible means of perceiving the place of human beings in a particular culture," ${ }^{159}$ and provided the people of Tokugawa Japan with immediately visible manifestations of their fears. With the rich history of the supernatural at their disposal for inspiration, artists never had to look far for their next eerie subject.

\footnotetext{
${ }^{157}$ Sumie Jones and Kenji Watanabe, An Edo Anthology: Literature from Japan's Mega-City, 1750-1850 (Honolulu: University of Hawaii Press, 2013), 22.

${ }^{158}$ Marius B. Jansen, China in the Tokugawa World (Cambridge: Harvard University Press, 1992), 4.

${ }^{159}$ Yamamoto, Introduction to Japanese Ghosts \& Demons, 9-13.
} 
These, in turn, have offered inspiration for artists today that continue to draw on the ubume and other yōkai for inspiration.

\section{Popularity of the Grotesque}

It was not until the boom in printing and spread of literacy of the Tokugawa period that visual representations of yōkai, including the ubume, flourished due to popular demand and a remarkable number of artists that rose to meet that demand. Several factors contributed to make the atmosphere ripe for such a surge in creativity but the main factors were relative peace, which allotted people more free time for leisurely activities as well as education, and the rise of the merchant class that provided them with the entertainment they sought. Travel was also an immense factor deserving of its own thesis. In short, individuals had more resources at their disposal to travel the country. In addition, the official system of alternate attendance, or sankin-kōtai, ensured a constant flow of people from Edo proper to other major cities or more rural areas. Under the Shogunate, these men, whose wives and children were required to stay behind in Edo, spread the culture of the capital throughout Japan and at the same time brought back with them the culture of the places to which they were sent. ${ }^{160}$ Naturally, folklore was a part of this culture.

But why was the monstrous so popular, as opposed to the reserved aesthetics and poetic world of the Heian period? As Reider notes, "the social stability at the beginning of the seventeenth century made the terror and death associated with civil war a thing of

\footnotetext{
${ }^{160}$ Constantine Nomikos Vaporis, "Assignment: Edo," in Tour of Duty: Samurai, Military Service in Edo, and the Culture of Early Modern Japan, 102-127. University of Hawai'i Press, 2008, accessed December 10, 2017, http://www.jstor.org/stable/j.ctt6wqtsd.8.
} 
the past. Thus, people could regard terror and strange phenomena as entertainment."161 That being said, it didn't mean that the fear had been completely stripped from the strange, as evidenced by the ritual practice of “ $k \overline{o s h i n m a c h i}$ 庚申町, a nightlong vigil during which no one should sleep. Tales about the strange... served to keep people awake particularly well on these occasions."

Even before ukiyo-e artists began to portray the strange through visuals, the hyakki yagyō had made its way from the Kyoto court to the Edo capital in the form of hyaku monogatari, or one hundred stories, along with a plethora of other tales from all over Japan. The rural and the urban mixed and mingled in the form of this game, "at which spooky stories, called kaidan, were exchanged one after another with the intent of inducing a supernatural experience." ${ }^{\prime 163}$ As the stories, which were generally short and to the point (not unlike setsuwa narratives) were told, the lighting would be decreased by putting out a candle after each one. It was thought that once the participants got to the last candle, something terrifying would happen. This shows that the monstrous was still scary but it had the potential to be entertaining as well, a precursor to contemporary depictions of the uncanny, such as those found in horror films.

Although merchants were technically at the bottom of the social hierarchy imposed by the Tokugawa government, they proliferated in Edo and indeed in other major cities, such as Osaka. They capitalized on the popularity of hyaku monogatari,

\footnotetext{
${ }^{161}$ Noriko T. Reider, "The Appeal of "Kaidan," Tales of the Strange," Asian Folklore Studies 59, no. 2 (2000): 266. doi:10.2307/1178918.

${ }^{162}$ Ibid., 267.

${ }^{163}$ Foster, The Book of Yōkai, 43-44.
} 
piggybacking on the literary foundations discussed in chapter two. The Konjaku monogatari was even revisited, and it is within this new edition that we see one of the earliest depictions of the ubume.

\section{Envisioning the Ubume}

Made possible by the advances in printing, Izawa Banryō (1668-1730) published the Kōtei konjaku monogatari, or Emended Tales of Times Now Past, in 1720 and 1722, the first time the original collection was widely circulated. ${ }^{164}$ Banryō, one of many authors working under Confucian influence, ${ }^{165}$ reworked the stories according to how he perceived would best fit a Tokugawa audience. He included the story of the ubume, with three distinct changes: he changed the characters used in the original from 産女 to 姑獲鳥, took out the part at the end that claimed the apparition might have been a fox playing a trick on humans, and included an accompanying image by an unknown artist. ${ }^{166}$

\footnotetext{
${ }^{164}$ Shimazaki, "Figures of the Ubume and the Breakdown of Theater Tradition,” 200.

165 Jason Ananda Josephson, The Invention of Religion in Japan (Chicago: University of Chicago Press, 2012), 175-176.

${ }^{166}$ Shimazaki, "Figures of the Ubume and the Breakdown of Theater Tradition," 201.
} 


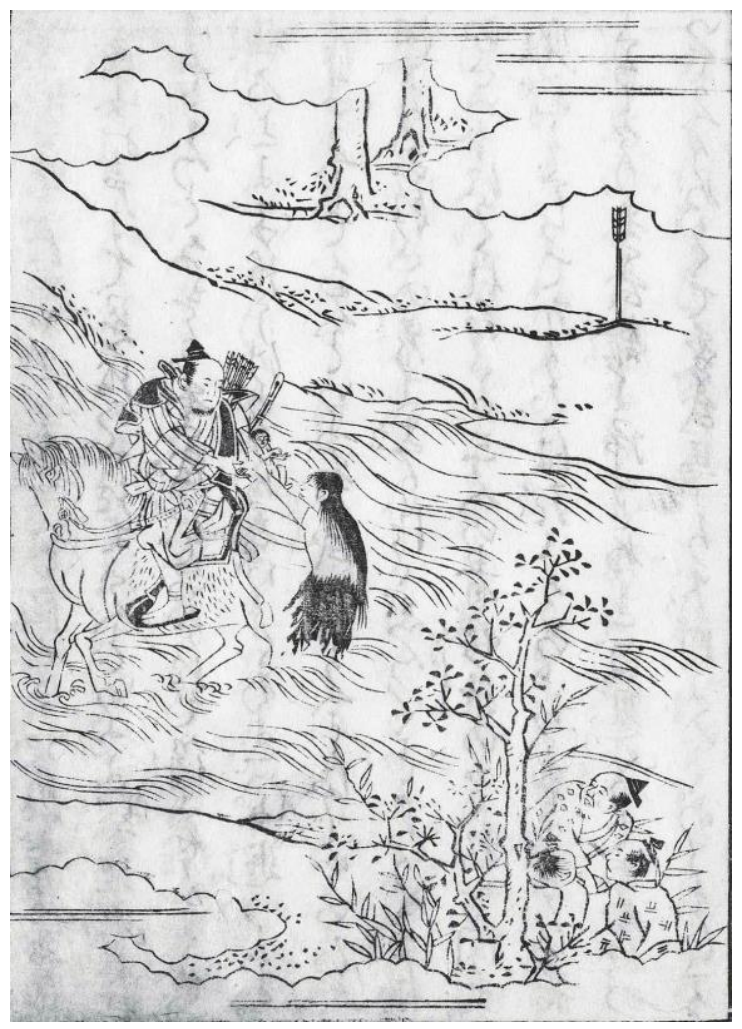

Figure 4.1: Banryō's ubume. ${ }^{167}$

This image (Figure 4.1) shows the ubume passing her baby to Suetake, as well as the men that secretly follow him hiding in the bushes. In the original Konjaku, she is not described in visual terms. However, by 1722, the trickle-down effect of beliefs and customs from the elite to the commoners had disseminated to the point of forever changing the landscape of social religion and the ubume would have been a well-known figure. The fate of loved ones dying in childbirth would have been a widespread concern, along with the practices that had developed to avoid the religious ramifications of this fate. It wasn't just the nagare kanjō and symbolic mifutatsu that temples promoted; priests, particularly of the Sōtō sect, may very well have invented some of the ubume and kosodate yūrei

${ }^{167}$ Ibid., 202. (One time fair usage). 
narratives, or at the least "co-opted" them for their own purposes. ${ }^{168}$ In other words, the non-secular realms used folklore to promote their ideologies, and the services they offered. Put another way, the hegemonic patriarchy of Buddhism used birth narratives to spread their morals. We have already seen how Shōsenji deployed the Ketsubonkyō, and in the next chapter, I introduce two more sacred spaces related directly and indirectly to the ubume.

Interestingly, Banryō's visual version stays surprisingly true to the original despite the changes he made to the text as a whole. Suetake meets the ubume in the river, and in the back we can see the arrow he promised to leave on the other side as proof of his encounter. Typical of a ghost, we cannot see the ubume's feet, and her kimono is "drenched in blood...suggesting that she is suffering in the Blood Pool Hell.",169

Toriyama Sekien's (1712-1788) was one of the most famous artists to take advantage of the popularity of the weird. He combined the practice of hyaku monogatari with "a broader zeitgeist, a kind of encyclopedic way of thinking about the world," spurned by the Neo-Confucian emphasis on examining and documenting everything. ${ }^{170}$ He produced a collection of encyclopedias, the first of which being the Gazu Hyakki Yagyō (画図百鬼夜行, An Illustrated Catalog of the Demon's Night Parade). ${ }^{171}$ It is in this work that he includes the ubume, pictured in Figure 4.2. Interestingly, in this volume,

\footnotetext{
${ }^{168}$ Iwasaka and Toelken, Ghosts and the Japanese, 10. See also Tsutsumi Kunihiko, “Kosodate yūrei tan no genzō Sōtō shū sōsō girei wo tegakari to shite," Kyoto Seika daigaku kiyō 93, no. 1.

${ }^{169}$ Shimazaki, "Figures of the Ubume and the Breakdown of Theater Tradition," 201.

${ }^{170}$ Foster, The Book of Yōkai, 47.

${ }^{171}$ Komatsu, Yōkai Culture, 21.
} 
unlike the later ones, he is sparse with his language, which may suggest that these yōkai "were already so deeply entrenched in the popular imagination that no explanation was necessary." ${ }^{172}$

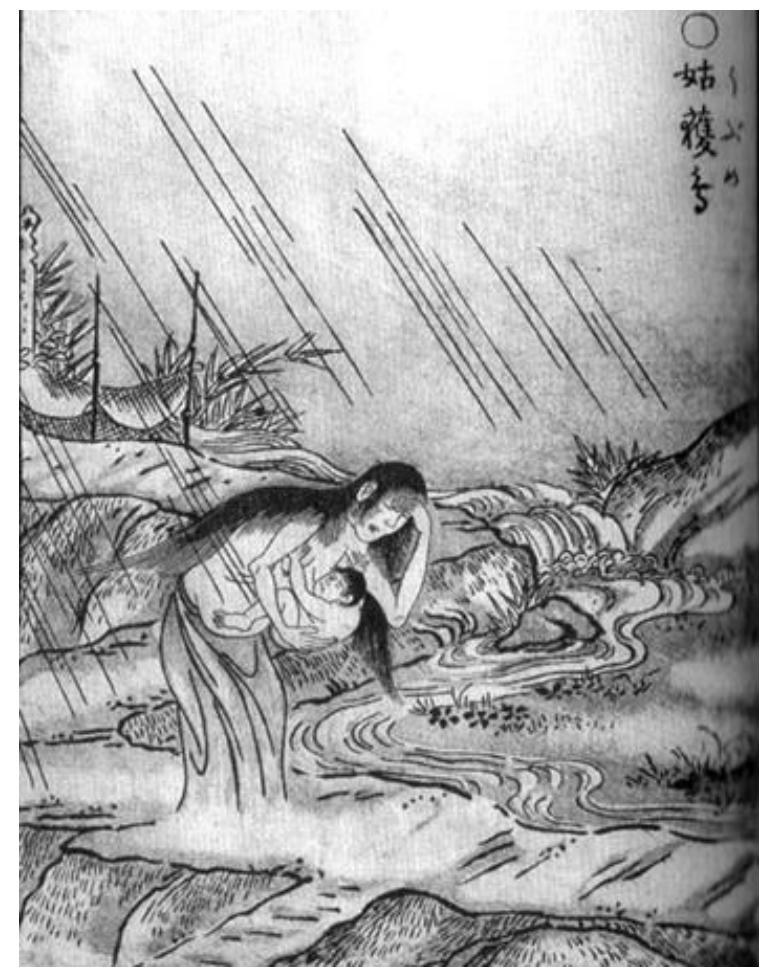

Figure 4.2: Toriyama Sekien's ubume. ${ }^{173}$

Sekien's version of the ubume is both similar and different to the preceding Banryō version (Figure 4.1). She is in water which flows from behind her and into the foreground, as if to imply that she has been traversing the river for quite some time and will continue until she finds someone suitable to take her ghostly infant. His version also alludes to her Chinese counterpart, the guhuoniao, or kokakuchō in Japanese. He uses the

\footnotetext{
${ }^{172}$ Foster, The Book of Yōkai, 48.

${ }^{173}$ Shimazaki, "Figures of the Ubume and the Breakdown of Theater Tradition," 203. (One time fair usage).
} 
ideographs associated with kokakuchō, and her hair resembles the feathers of a bird. Her appearance is distinctly Japanese in that she is in a soaking wet kimono and she has no feet, one of the ways in which a ghost is clearly demarcated as such. What makes his version the most Japanese, however, is the nagare kanjō behind her on the banks of the river which does not appear in Banryō's version. There is also no trace of Suetake, and Sekien's ubume must continue her quest to find someone to whom she can pass her baby. Thereafter, other artists began depicting the ubume without any allusions to the Konjaku or to Suetake. While female ghosts appeared in earlier literature, such as the Genji monogatari (The Tale of Genji), written in the early eleventh century, it was during the Tokugawa period their appearance became standardized. Because female ghosts were extremely popular in literature, and the theatre, they proliferated in the arts along with yōkai. One such example is the eerie version in Figure 4.3. 


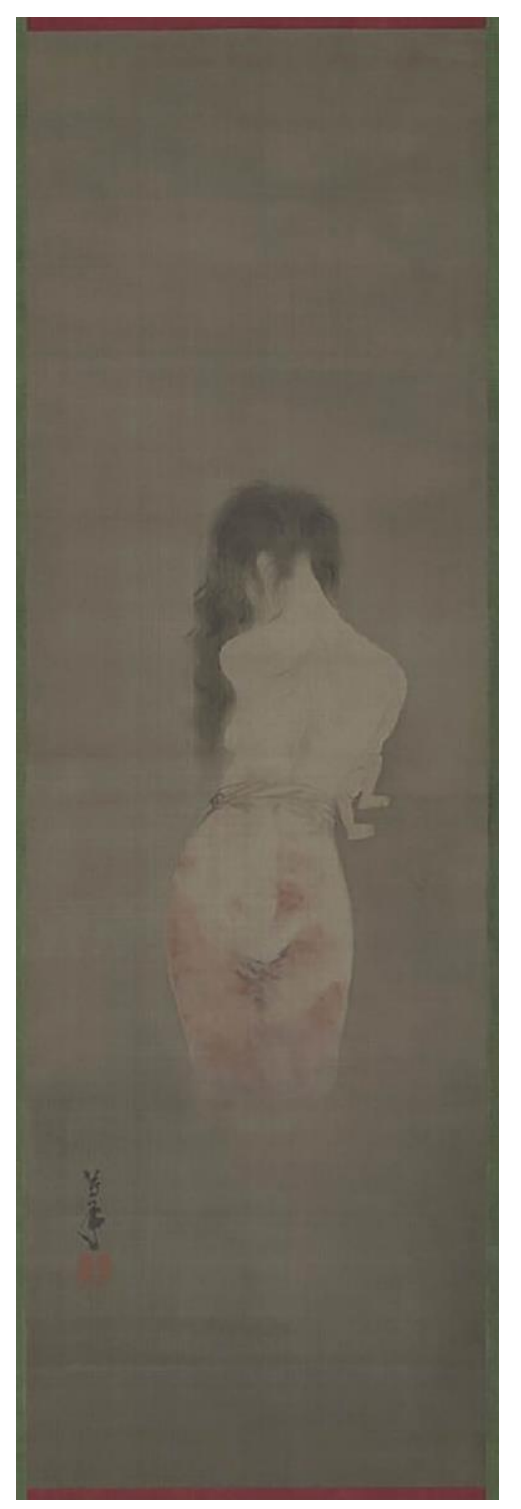

Figure 4.3: 幽霊之図 うぶめ by Tsukioka Yoshitoshi (1839-1892). ${ }^{174}$

Tsukioka was another Tokugawa artist that depicted the supernatural and was known for his particularly violent drawings. His ubume alludes neither to the Konjaku, nor the religious practices surrounding the ubume, nor water, although there is a misty quality about the image. His ubume is also not seen from the front and the only part of

\footnotetext{
${ }^{174}$ From the Digital Collections of Keio University Libraries (http://dcollections.lib.keio.ac.jp/ja/ukiyoe /1173). (One time fair usage).
} 
the baby we can see are its feet. Tellingly, her clothes are stained with blood and her lower body fades into nothingness in typical yūrei fashion.

Another popular yūrei to depict was the "Nightly Weeping Rock" legend, in which a pregnant woman is murdered and her spirit takes up residence in a rock that cries, as in in the example of Figure 4.4. In this legend, however, instead of this woman becoming an ubume or kosodate yūrei to raise the baby, Kannon raises it by feeding it candy. Kannon is a Bodhisattva, or one who has attained enlightenment but remains in this realm to help others, and is discussed further in the next chapter. The baby is eventually delivered to its father. ${ }^{175}$ In a different version of the story, which places the rock in an actual location along the Tōkaidō, the major road connecting Tokyo and Kyoto, more emphasis on put on the religiosity of the pregnant woman. Because of her faith in Buddhism, Kannon "caused a stone by the side of the road to cry for help, which was heard by a priest... who took the child from the woman's womb and fed it with candy." ${ }^{176}$ In the first account, the husband avenged his pregnant wife. In this, her child grows up and avenges her. The image above depicts the first narrative, and shows the husband holding the baby while watching nervously the ghost of his dead wife.

\footnotetext{
${ }^{175}$ Ibid., 26.

${ }^{176}$ Jilly Traganou, The Tōkaidō Road: Traveling and Representation in Edo and Meiji Japan (New York: RoutledgeCurzon, 2004), 237.
} 


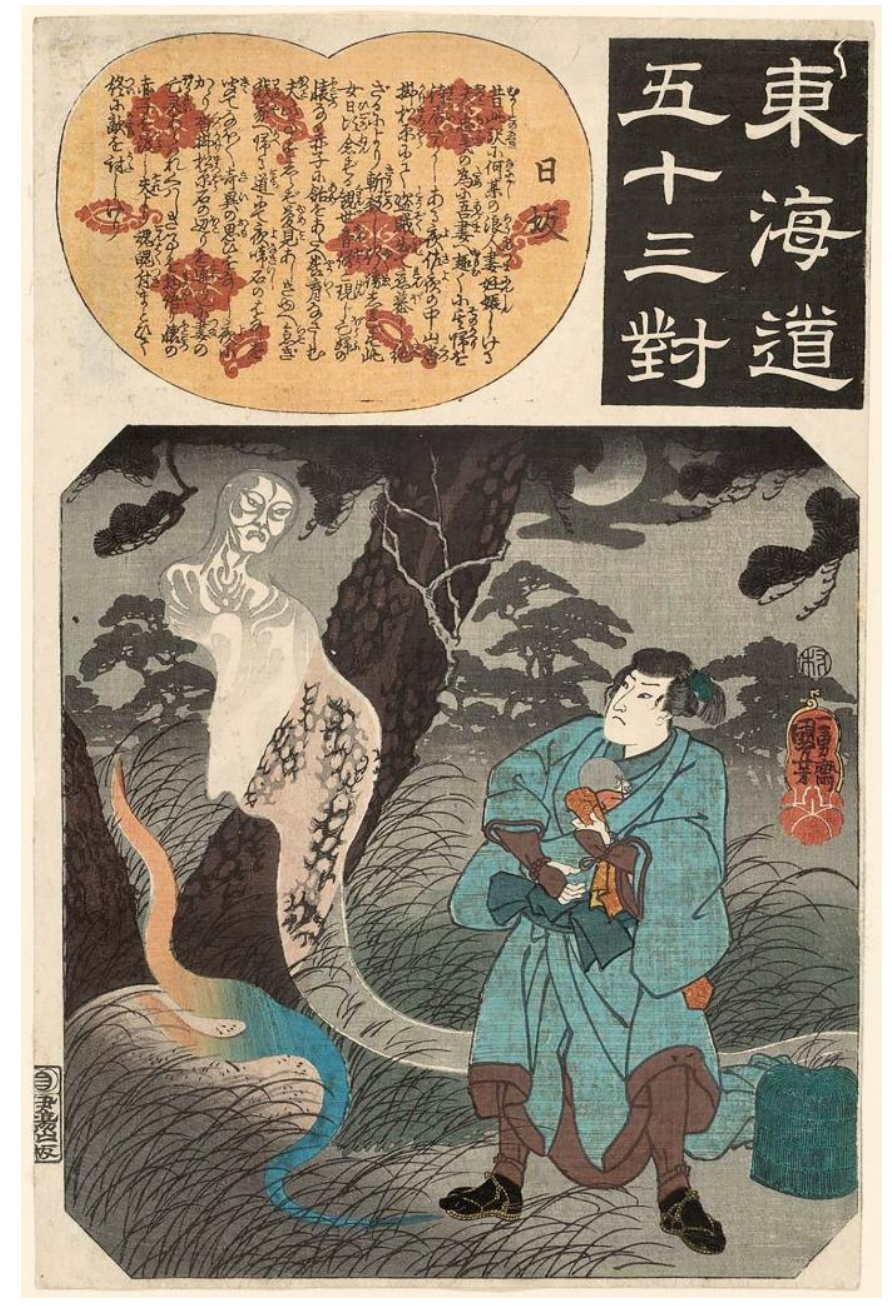

Figure 4.4: Nightly Weeping Rock by Utagawa Kuniyoshi (1797-1861). ${ }^{177}$

From Print to Stage

Not surprisingly, the monstrous could not be contained on paper alone. Kabuki theatre originated in the 1600s as a form of entertainment combining dance and song performed by women, but due to concerns about the morality of these performances, it was suppressed until older men took on all the roles. By the 1700s, "Kabuki had become an established art form that was capable of the serious, dramatic presentation of genuinely

${ }^{177}$ Jordon, Japanese Ghosts \& Demons, 27. (One time fair usage). 
moving situations." 178 While Noh theatre generally catered to the upper classes, "Kabuki became the theatre of the townspeople and the farmers." 179

Kabuki audience's taste for the monstrous is reflected in the myriad plays about the dead, which often featured female ghosts. Shimazaki refers to the plays which feature such abject women as "household-disturbance" plots. ${ }^{180}$ In other words, female ghosts, as the inverse of what a woman was supposed to be (a mother and wife), were particularly palpable to audiences, not unlike the horror films of modern entertainment. What better ghost to use for this purpose than the ubume?

Not only did one of the most famous Japanese ghost stories originate as a Kabuki play, Yotsuya kaidan, but in its first running in 1825, the main female character, Oiwa, was portrayed as an ubume. Audiences would have been able to identify her as such because she emerges from a nagare kanjō and is holding an infant, just as the man who ultimately caused her death, Iemon, is about to pour water onto the nagare kanjō (not unlike Sekien's ubume). From descriptions of this performance, we also know she was drenched in blood from the waist down. The scene below is from Gunji Masakatsu's transcription:

"Iemon snaps at Oiwa. Oiwa in turn shows him the baby cradled in her arms. (Iemon shows emotion.)

\footnotetext{
178 The Editors of Encyclopædia Britannica, "Kabuki," April 25, 2017. https://www.britannica.com/ art/Kabuki.

${ }^{179}$ Ibid.

${ }^{180}$ Shimazaki, "Figures of the Ubume and the Breakdown of Theater Tradition," 212.
} 
Iemon: Can it be! The dead woman appears to have raised the boy! (Iemon shows emotion.)

Iemon joyfully takes the baby in his arms.

Iemon: Despite all that came between us, you're still my wife. Well done, well done. If those are your true feelings, depart in peace. Hail Buddha, hail Buddha.

Iemon cradles the baby and chants Buddhist prayers. Oiwa covers her ears with both hands, blocking out Iemon's prayers.

A moment later, Oiwa suddenly disappears. In his shock, Iemon drops the baby, who instantly turns into a stone statue of the Bodhisattva Jizō."181 Even without going into the details of the plot, which is full of twists, revenge, and death, this scene encapsulates elements of the basic ubume narrative. In 1825, the ubume, and the Blood Pool Hell, would have still been imminent threats. As Shimazaki points out, "Oiwa, however, is responsible for her son's death. In fact, he is her very first victim: the rats that act as her agents throughout the play drag the infant to her immediately after she dies in act $2 .{ }^{\prime 182}$ This is in sharp contrast to the typical ubume narrative, in which the maternal ghost lingers because she is trying to help her baby (whether it is alive or dead).

Nanboku, in contrast to the trend in Kabuki to focus on historical dramas, came to place ghosts as the central motifs in his play, and turned the ubume into something more malicious, more akin to the Chinese version that wreaked havoc by stealing the children of living mothers. Other plays contained plots surrounding pregnancy, sometimes with an

\footnotetext{
${ }^{181}$ Ibid., 195-196.

${ }^{182}$ Ibid., 198.
} 
ubume appearance, but they were usually tied to stories of "succession troubles and power struggles in daimyo domains." 183

This new version of an ubume was a result of the culmination of religious beliefs, Confucian ethics, and attitudes towards the female body that came to be seen as "borrowed goods." 184 Glassman stresses, "Religious ideologies surrounding pregnancy and childbirth are always, of course, related to kinship beliefs," 185 and as I have noted, the kinship beliefs in Japan came to be increasingly patrilineal after the Heian period. The more sympathetic version of the ubume was still a cause of fear in that no one wanted to become an unhappy spirit, and no one wished that fate upon their family members. Nanboku did include in other plays the more "conventional overtones of ubume sorrow," but these were usually not the main focus of the plot. ${ }^{186}$ Yotsuya kaidan, in contrast, focuses on the vengeful ubume who "flaunt[s] in front of her husband her total lack of concern for her son," and "retains her own resentments and determination to extinguish, instead of preserve, her husband's family line."187

\section{Summary}

It is telling that in the end, the ubume Oiwa does not achieve salvation after she exacts her revenge on Iemon, as was the usual outcome of such ghostly tales. ${ }^{188}$ By the end of

\footnotetext{
${ }^{183}$ Ibid., 212.

${ }^{184}$ In Japanese, hara wa karimono (腹は借り物).

${ }^{185}$ Glassman, "At the Crossroads of Birth and Death,” 176.

${ }^{186}$ Shimazaki, "Figures of the Ubume and the Breakdown of Theater Tradition," 216-217.

${ }^{187}$ Ibid., 227.

${ }^{188}$ Ibid.
} 
the Tokugawa period the ubume, infused with the religious connotations promulgated by the Shinto taboos of blood, the Buddhist notion of karmic retribution, and the Confucian ethics of familial piety, would have been a well-known image of female abjection. She would also be, to many, a very real fear considering that pregnancy resulted just as often in death as it did life before modern medicine. She was the physical embodiment of these anxieties surrounding childbirth, the tangible result of a natural human process going spiritually wrong. Glassman sums up, "at the beginning of the medieval period, death in childbirth was a family tragedy; by the end of the medieval period it had become evidence of the sinful karma of the dead woman." ${ }^{189}$ During the eighteenth and nineteenth centuries, the anxieties surrounding this (and other fears) were captured on paper and on stage.

Oiwa, betrayed by her husband, acts as an abject ubume and embodies, and somewhat foreshadows, the social changes and attitudes surrounding the female body. It was around this time that a more "fetocentric rhetoric" 190 was developing. At first, this had less to do with religious or moral issues, and mabiki, or infanticide, was still practiced. ${ }^{191}$ As Hardacre explores, abortion (unlike pregnancy) during the Tokugawa period was not ritualized. However, while woman had already been conflated with mother, especially during the years following the Heian period, it was during the Tokugawa period that women significantly came to be seen as little more than a means to

\footnotetext{
${ }^{189}$ Glassman, “At the Crossroads of Birth and Death,” 180.

${ }^{190}$ Hardacre, Marketing the Menacing Fetus, 4-5.

${ }^{191}$ Laws against infanticide on the same level as homicide began in 1873: Hardacre, Marketing the Menacing Fetus, 48.
} 
reproduce. These ideologies of motherhood and the stigmatization of non-reproduction were exasperated when Japan began engaging in overseas warfare, and the need for a population increase put more pressures on women to have children. The frustration and desperation of Oiwa as ubume can easily be plucked from 1825 Edo and transplanted in contemporary depictions of monstrous mothers. 


\section{CONTEMPORARY CULMINATIONS}

"The same old demons will always come up until finally you have learned your lesson, the lesson they came to teach you." - Pema Chödrön ${ }^{192}$

While modernity has created new sets of anxieties and new ways to deal with them, figures of folklore such as yōkai and yūrei have had to find new places to thrive. As

Foster notes, "yōkai are born from the dual acts of reading and writing the world around us; they develop from symbiotic processes of interpretation and creation." ${ }^{193}$ In contemporary society, such figures do not help us understand the incomprehensible, at least not in the way they did in the past. Additionally, many yōkai have been transformed into cute or even sexy mascots, monsters we keep in our pockets (and now in our cell phones), ${ }^{194}$ not unlike how Toriyama Sekien captured and confined them to the page. The kappa, for example, which was said to pull victims into bodies of water and consume their insides, is now a recognizable mascot for a sushi restaurant chain called Kappa Sushi. The difference, in terms of the ubume, is that she cannot be transformed so easily into a kawaii, or cute, character. However, considering the quote above by Pema Chödrön, it would be unwise to take the route of Inoue Enryō and once again try to demote folklore to the realms of fantasy or naïve superstition.

\footnotetext{
${ }^{192}$ Pema Chödrön, The Wisdom of No Escape: And the Path of Loving-Kindness (Boston: Shambhala Publications, 1991), 41-42.

${ }^{193}$ Foster, The Book of Yōkai, 244.

${ }^{194}$ For example, many Pokémon either allude to or explicitly refer to figures of Japanese folklore. One of the most overt examples is the character Drowzee (in Japanese, スリープ, or Sleep). Drowzee's appearance, which resembles a tapir, also closely resembles the Baku, a protective creature of Chinese origin, which are thought to eat the bad dreams of humans. In Pokémon, Drowzee puts people to sleep so that it can eat their dreams.
} 
Where, then, does the ubume figure into contemporary yōkai culture? And what of the anxieties surrounding childbirth, proper care of the dead, and familial duty that she embodied? Today, the dialogue between the sacred and the ubume is not as overtly expressed in terms of fear of the Blood Pool Hell or the salvation of women. What is still prevalent is the dualistic condemning/liberating aspect for women in Japanese religion, as the ideology of motherhood is still pervasive and non-reproduction is still stigmatized.

While many yōkai and yūrei today have found new avenues to spread amongst people, such as manga, anime and videogames, the ubume is not as prolific in these because she cannot be sexy or cute (kawaii-ified). She is, however, often used in contemporary literature and horror movies, sometimes explicitly and sometimes more nuanced. She also figures into religious spaces in the form of the Ubume Kannon and Kosodate Kannon, although this connection is not nearly as interactive and synergetic as in the past, when the mifutatsu and nagare kanjō practices were reinforcing and being enforced by the fear of the ubume and kosodate yūrei. I believe this speaks to the trend of the personalization of religion, in that individuals approach their spirituality in unique and as-needed ways. For women, anxieties surrounding maternity do not so much revolve around the implications of this for their afterlife, as was the case mainly in the Tokugawa period. Rather, with the ideology of motherhood perhaps more pervasive than it has ever been given Japan's declining birthrate and aging society, the ubume and more commonly the kosodate motifs are more geared towards aiding women, and children, in this life time. Even with the case of mizuko kuyō (水子供養), memorial services for aborted or 
miscarried fetuses, which became popular in the 1970s, women responded in immensely personal ways. ${ }^{195}$

\section{The Place of Folklore in Japanese Society Today}

When discussing folklore in contemporary societies, the terms "folklorization" and "folklorism" come to the forefront. Folklorization, as defined by John H. McDowell, "means to remove traditional expressive culture from an original point of production and relocate it in a distanced setting of consumption." 196 Michael Dylan Foster explores the similar concept of "folklorism" using the example of the kappa, or water goblin,"197 perhaps the most well-known yōkai today. Foster argues that, "through folklorism, artists, writers, cartoonists, and commercial interests have transformed the kappa from a malicious and unpleasant water deity into a harmless and loveable mascot." ${ }^{\text {"198 }}$ It is true that many yōkai have been 'modernized' in the realm of manga, anime, video games, and movies, plucked from setsuwa and woodblock prints and placed in the pockets of children or spread across the big screen, within and beyond Japan. Regina Bendix

\footnotetext{
195 The spiritualists who originally promoted the phenomena sensationalized tatari, the spirit attacks of the deceased, and claimed the aborted or miscarried fetuses were causing harm to women and even their living children. However, many participants advocate for the service not out of fear or even guilt. For more on this see Hardacre, Marketing the Menacing Fetus in Japan.

${ }^{196}$ John H. McDowell, "Rethinking Folklorization in Ecuador: Multivocality in the Expressive Contact Zone," Western Folklore 69, no. 2 (2010): 182, accessed January 6, 2018, http://www.jstor.org/stable/2 7896341.

${ }^{197}$ Michael Dylan Foster. "The Metamorphosis of the Kappa: Transformation of Folklore to Folklorism in Japan,” Asian Folklore Studies 57, no. 1 (1998): 1-24. doi:10.2307/1178994.

198 Ibid., 1.
} 
explains this as "out of context, folklore which has been altered and even invented for specific purposes."199

If we stop here and consider the removal from original source into a different utilization, then it could be argued that the inclusion of oral folk stories in the Konjaku was an act of folklorization. Similarly, if we consider that when Tokugawa artists drew yōkai and confined them to the spatial dimensions of the page, this too would seem to be folklorism, no different from manga artists today that include figures from folklore.

However, Foster also points out that "folklorism may, in the end, serve a function remarkably similar to the original function of the item of folklore." ${ }^{200}$ I agree with this, as well as McDowell's argument for the "multivocality of cultural production,"201 or the ability of folkloric products to "speak to different audiences and serve different purposes"202 with equitable potency. While an in-depth analysis of the modernization of yōkai is beyond the scope of this thesis, contemporary configurations of yōkai, including the ubume, should not be swept under the rug of "fakelore."203

That being said, the context of yōkai in Japanese society today has to be taken into consideration, just as when examining depictions from the past. As stressed, even the definition of what a yōkai constitutes is liminal, and so too is their place. Today one may be more concerned with being robbed than running into a yōkai or yūrei at night. When

\footnotetext{
${ }^{199}$ Regina Bendix, “Folklorism: The challenge of a concept," International Folklore Studies, 6 (1988): 5.

${ }^{200}$ Ibid., 12.

${ }^{201}$ McDowell, "Rethinking Folklorization in Ecuador," 181.

${ }^{202}$ Ibid., 184.

${ }^{203}$ Foster, "The Metamorphosis of the Kappa," 11.
} 
one hears footsteps behind them as they walk home they most likely do not think to stop and let Beto-beto-san pass by. But yōkai and references to Japanese legends are everywhere, from advertisements in the subway to signs warning of the dangers of playing near water. Museums across the country display the works of Tokugawa artists and their depictions of the monstrous consistently draw crowds, such as the recent exhibition of Tsukioka Yoshitoshi's "One Hundred Views of the Moon" at the Ota Memorial Museum of Art in Tokyo in September 2017.

In terms of the ubume, with medical advances the threat of maternal and infant mortality has subsided. As of 2017, Japan was second to last out of 225 countries, behind Monaco, in infant mortality rates, with 2.00 deaths per 1,000 live births. ${ }^{204}$ Out of 184 countries, as of 2015, Japan was ranked 171 in maternal mortality rate, with five deaths out of 100,000 live births. ${ }^{205}$ I posit that because of this, as well as the overall changes in religiosity in contemporary Japan, anxieties related to the afterlife and spiritual repercussions have significantly subsided. In other words, uneasiness surrounding pregnancy is not due to the fear of the Blood Pool Hell or the possibility of becoming an ubume. However, this does not mean that the anxieties have disappeared completely. "Pregnancy is characterized by dynamic changes in both psychological and biological (e.g., neuroendocrine parameters) processes,"206 and in Japan the ideology of motherhood

\footnotetext{
${ }^{204}$ Data collected from the CIA World Factbook, accessed on December 17, 2017. https://www.cia.gov/ library/publications/the-world-factbook/rankorder/2091rank.html.

205 Data collected from the CIA World Factbook, accessed on December 17, 2017. https://www.cia.gov/ library/publications/the-world-factbook/rankorder/2223rank.html.

${ }^{206}$ S.C. Roesch, Dunkel Schetter, C., Woo, G., \& Hobel, C.J. (2004). Modeling the types and timing of stress in pregnancy. Anxiety, Stress, and Coping, 17(1), 88.
} 
and stigmatization of non-reproduction is more ubiquitous than perhaps it ever has been. Let us first explore the religious spaces related to these themes, and then the new media in which monstrous maternity appears.

\section{The Ubume, Kosodate Yürei, and the Spiritual}

Kannon (観音) is a Bodhisattva, or one who has attained enlightenment but remains in this world to help others. In Japan and China Kannon came to be portrayed as feminine. She is evoked in myriad stories, many found in the Nihon ryoiki and Konjaku and today is prayed to all over Japan. Interestingly, the most common feminine forms in Japan are related to motherhood, such as the Koyasu Kannon for safe delivery. ${ }^{207}$ However, there is also a Kosodate Kannon temple (in Tokyo) and an Ubume Kannon temple (in Shizuoka). While Jizō, the Bodhisattva associated with rescuing people from hell, was connected to the salvation of women via the Ketsubonkyō cult at Shōsenji, Kannon has also been connected to the salvation of women. Williams points out that "most pictorial depictions of the Blood Pool Hell center on the salvific powers of Nyoirin Kannon. The association of Kannon with this particular hell not only is founded on mandalas, but examples exist of gravestones of women with Nyoirin Kannon engraved on the stone."208 Nyoirin Kannon, like Jizō, is associated with the realms of rebirth.

These two religious spaces, while not as connected to the world of yōkai, exemplify one of the areas where the ubume fits today. This is not to say that the sacred does not interact at all with yōkai, however. At a shrine in Tokyo, Suiten-gū (水天宮),

\footnotetext{
${ }^{207}$ Schumacher, "Kannon Bodhisattva, Kannon Bosatsu, Lord of Compassion, Goddess of Mercy," Onmark Productions, accessed January 10, 2017, http://www.onmarkproductions.com/html/kannon.shtml.

${ }^{208}$ Williams, The Other Side of Zen, 159.
} 
which was recently renovated, a statue of a kappa was added. Suiten-gū is a shrine known for safe childbirth, while kappa are known as dangerous creatures that dwell in rivers. However, in this space, the kappa (Figure 5.1) has been transformed into a loving mother. The difference between the interaction of religion and yōkai, in terms of the ubume, is that the emphasis on the practices at such locations is not on the afterlife but this life, particularly in regards to maternity-related issues.

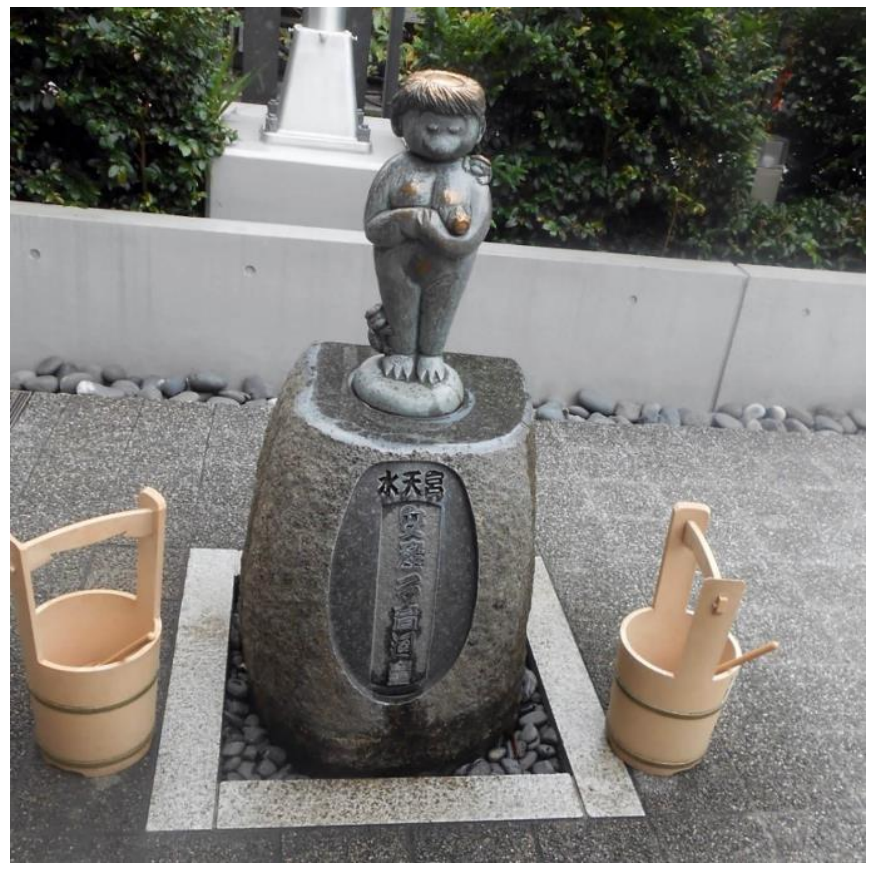

Figure 5.1: Kappa mother with children, nursing. Courtesy of the author.

The Kosodate Kannon (子育て観音) in Tokyo is located at the Kannon-dō of Kiyomizudera in Ueno Park, modeled after the temple of the same name in Kyoto. Originally founded in 1631, it was moved to its present location in 1694. Aside from being a major tourist attraction, individuals can come to this temple and pray to Kosodate Kannon, or the Kannon of childrearing. If they are trying to conceive a child, they can offer a doll to Kannon. Photos in that area were prohibited but in front of the enclosed image of the Bodhisattva, I saw an amassed pile of children's toys and every year, in 
September, they have a ningyō kuyō (人形供養), or a memorial service for the dolls that were given to Kannon. ${ }^{209}$ Figure 5.2 shows a poster advertising this event while Figure 5.3 shows eager participants behind the officiating priests. These are followed by Figure

\section{4, a statue of Kosodate Kannon found in a museum in Saitama.}

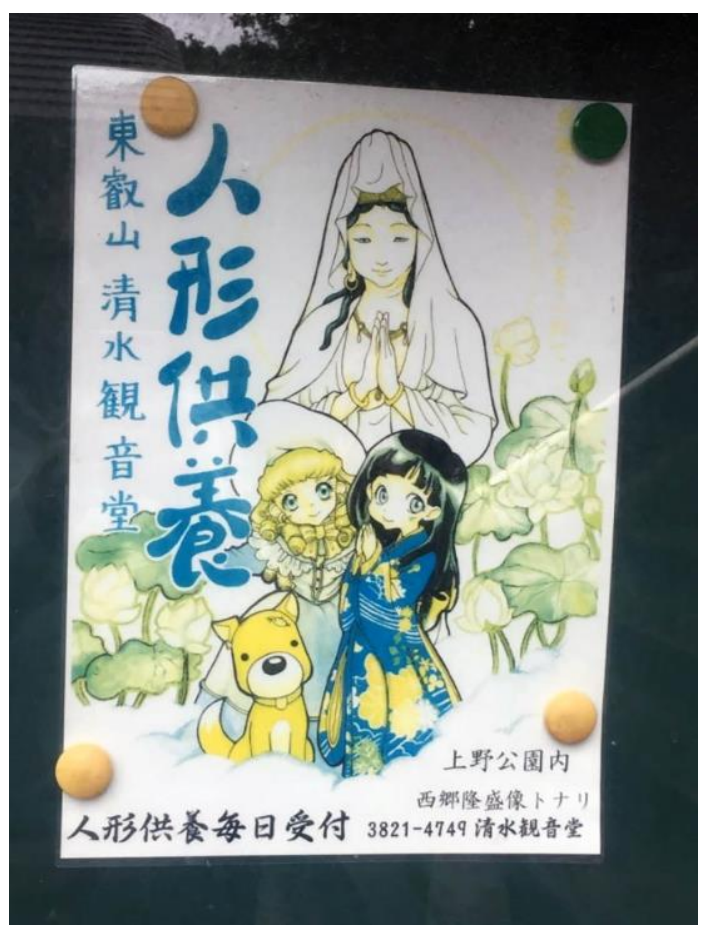

Figure 5.2: Advertisement for the ningyō kuyo service posted outside of the temple. Courtesy of the author.

\footnotetext{
${ }^{209}$ In another example of how personalized religion in Japan is today, many people bring their dolls to this service not to ensure their own children's wellbeing or to conceive a child but simply to thank their dolls, as opposed to throwing them away (Setsuko Kamiya, "Last rites for the memories as beloved dolls pass away," The Japan Times, October 15, 2006, https://www.japantimes.co.jp/life/2006/10/15/to-be-sorted/lastrites-for-the-memories-as-beloved-dolls-pass-away/\#.Wmj4J6inHIU). I was fortunate enough to attend this ceremony and there were indeed an eclectic array of participants, and dolls.
} 


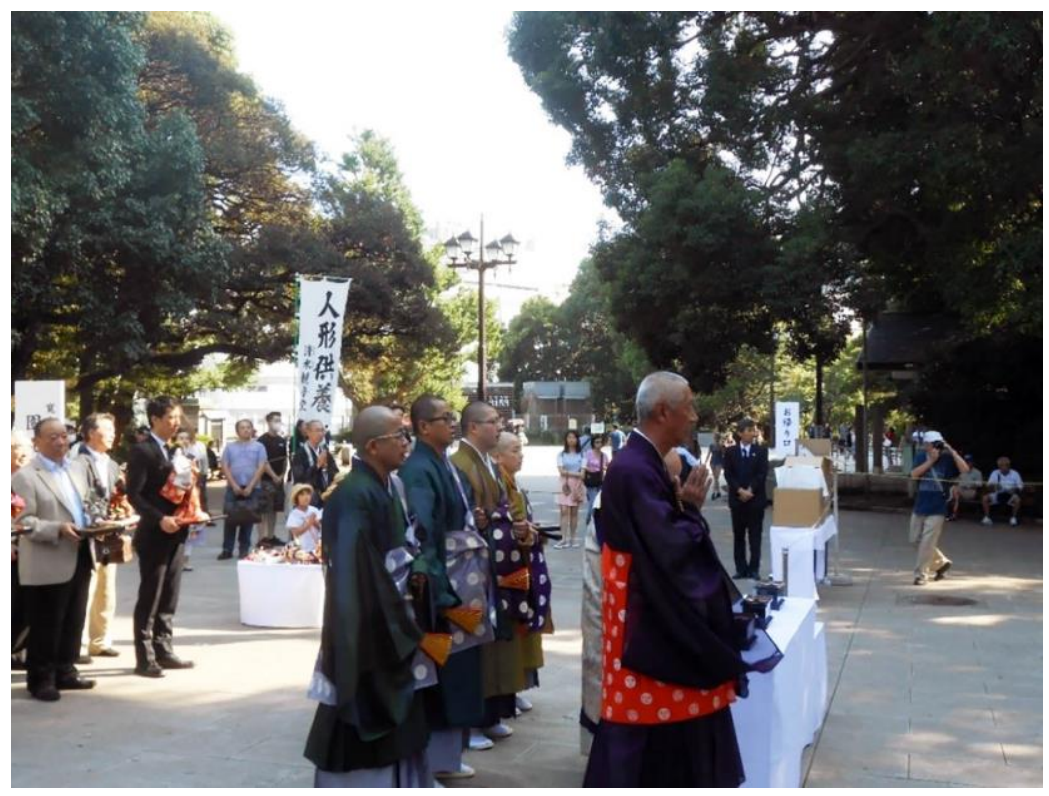

Figure 5.3: Priests officiating the ningyō kuyo ceremony with practitioners lined up behind them, waiting to place their dolls into the fire. Courtesy of the author.

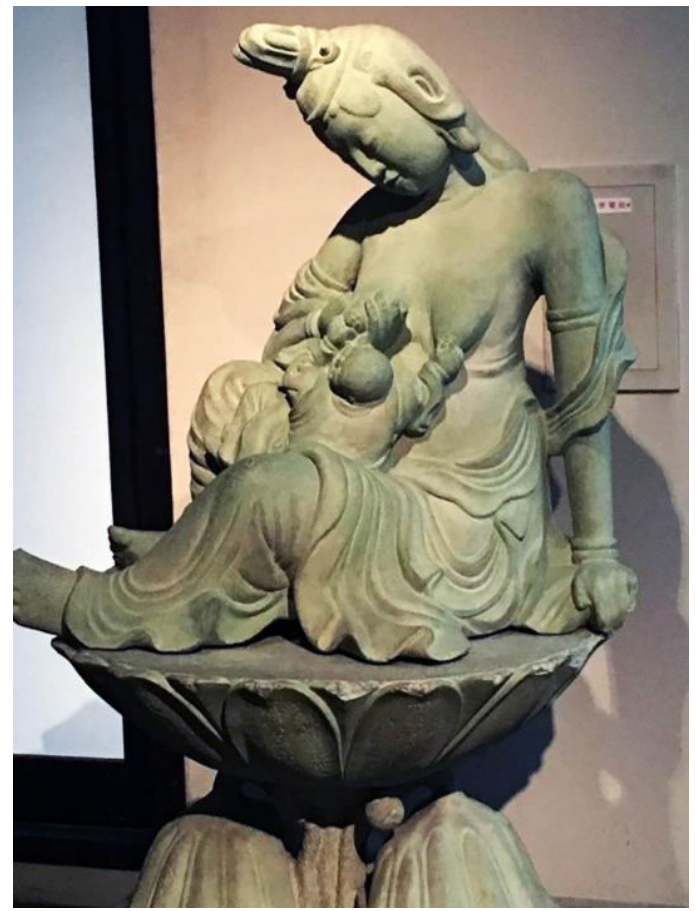

Figure 5.4: A statue of Kosodate Kannon at the Saitama Museum of History and Folklore. Courtesy of the author.

The Ubume Kannon (産女観音) temple, in contrast to the central location of the Kannon-dō in Ueno Park, is nestled in the countryside of Shizuoka in the area of Ubume 
(written with 産女), about an hour and a half from Tokyo via the Shinkansen. From the

Shizuoka train station it is about another half hour by bus, and then a ten-minute walk.

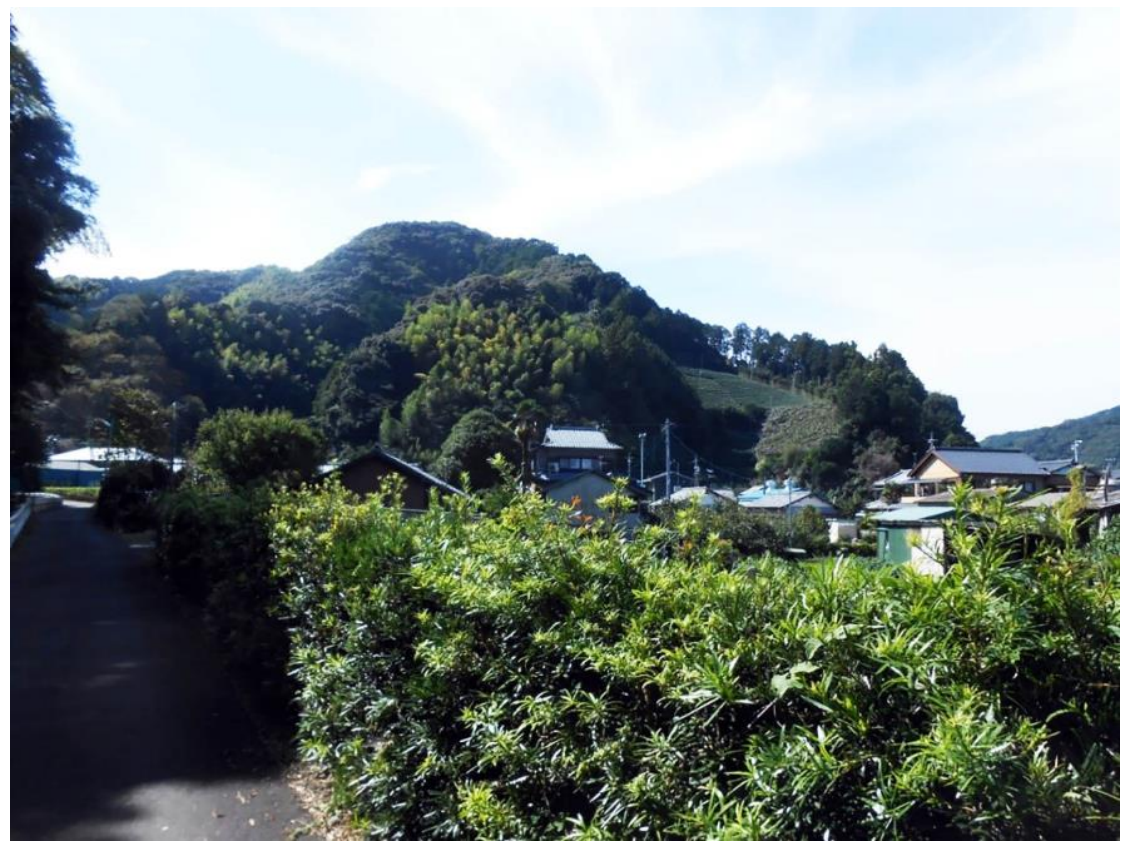

Figure 5.5: The beginning of the route to the Ubume Kannon temple. A forest to the left, a wall of bushes about waist high to the right. Courtesy of the author.

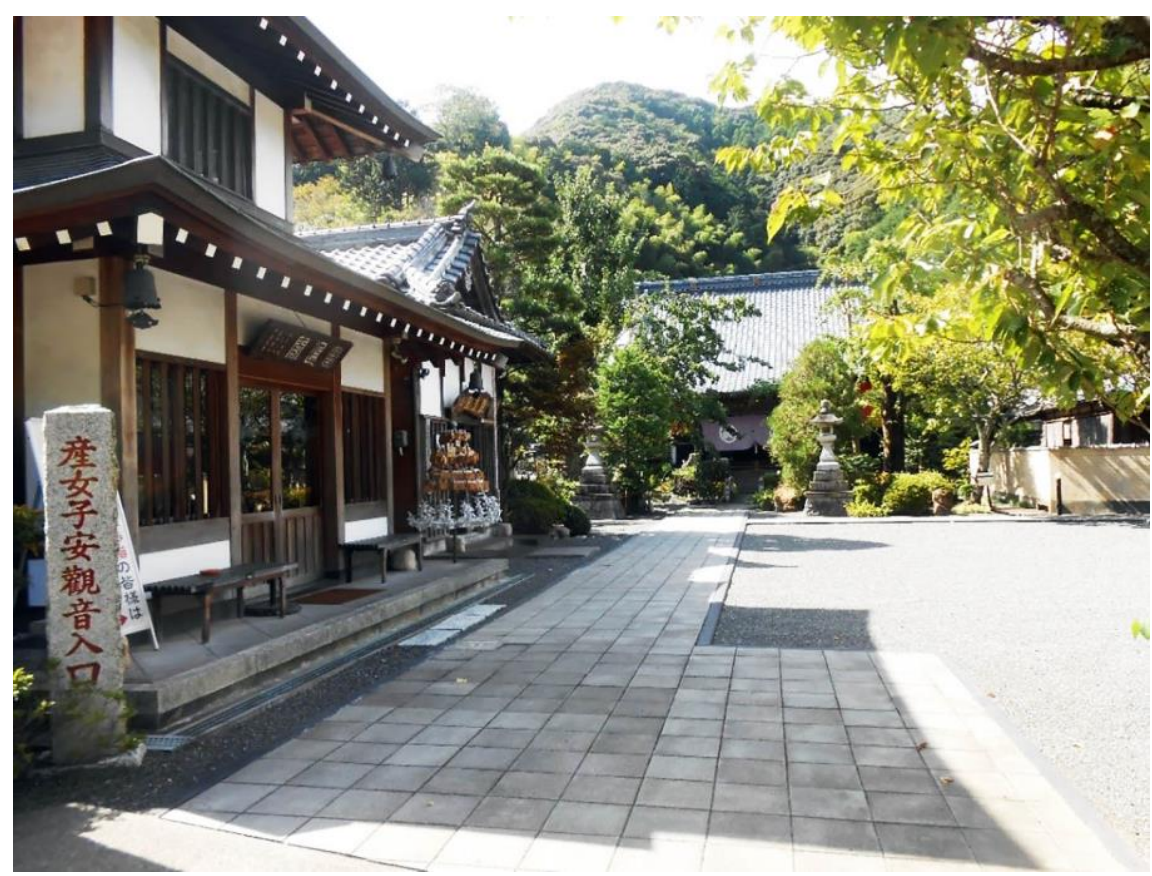

Figure 5.6: The entrance to the temple with stone marker and ema (絵馬, votive pictures) in the background. Courtesy of the author. 


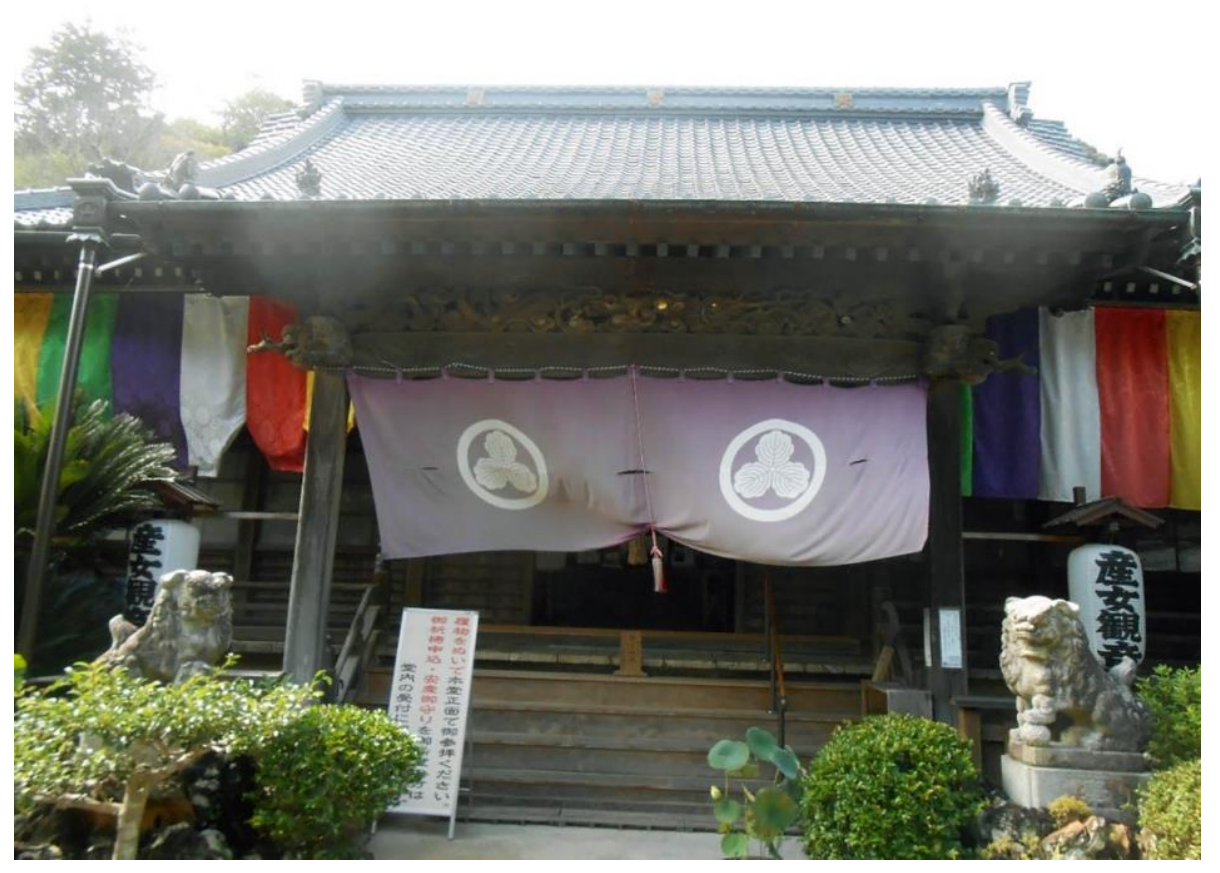

Figure 5.7: The Main Hall. Courtesy of the author.

At this temple (Figures 5.5-5.7), which also offers mizuko kuyō services, patrons can go and pray for easy delivery (安産), conception (子授け), and the general wellbeing of their children. Many of the ema at the temple reflect these wishes, as well as the Instagram posts of those who have visited the temple. ${ }^{210}$ Originally, the temple was founded after an ubume was placated and finally able to achieve peace. These spaces now offer women the opportunity to once again take their spiritual concerns into their own hands, even as the hegemony of the patriarchy dominates ideologies surrounding reproduction.

\section{Recent Depictions of the Ubume as Abject Mother}

While a woman drenched in blood from the waist down carrying an infant may not show up in the next Pokémon game or become the mascot of a town or spokes-yōkai for a

${ }^{210}$ These can be viewed here: https://www.instagram.com/explore/locations/111990623/. 
company, the image of the ubume is still invoked by artists today, mainly in literature and horror movies. ${ }^{211}$ The examples that follow have their own lessons to be gained from them but with the shift in religious application, they speak more to Japanese society as a whole then strictly concern with the afterlife. As Rosemary Jackson put it, "fantasies are never ideologically “innocent.","212

Before we turn to these examples, it is important to revisit the criteria for using the supernatural in fiction to influence religious belief as laid out by Davidsen: "to afford belief in the supernatural beings of the story, a text must present those supernatural beings as real within the story-world; to afford ritual interaction with said beings, a text must include model rituals and inscribe the reader into the narrative; to afford belief in the historicity of the narrated events, a text must anchor the story-world in the actual world." ${ }^{213}$ While contemporary depictions of folklore, in general, do not carry with them the same soteriological messages in the sacred sense that their predecessors of setsuwa and etoki did, they do still "dramatize areas of doubt, ambiguity, anxiety, and concern, ${ }^{214}$ which address an individual's place in society. These anxieties cannot be explained with yōkai as they once had been, but yōkai provide us with a way to address them, and digest them, more easily.

\footnotetext{
${ }^{211}$ I have also found the ubume to be a popular videogame character. In this media, she is usually depicted as a bird, or humanoid with bird-like qualities. However, the pregnancy narrative remains, even in the instances where the character has no human qualities, such as in the Onigiri MMORG (massively multiplayer online role-playing game).

${ }^{212}$ Rosemary Jackson, Fantasy: The Literature of Subversion (New York: Routledge, 2003), 122.

${ }^{213}$ Davidsen, "Fiction and Religion," 489-499.

${ }^{214}$ Iwasaka and Toelken, Ghosts and the Japanese, 58.
} 
姑獲鳥の夏, The Summer of the Ubume, is a novel published in 1994 by contemporary Japanese author Kyōgoku Natsuhiko (b. 1963). It was made into a film in 2005 and a manga in 2013. The novel, which was translated into English in 2009, takes place in the 1950s in the years following WWII. Told from the perspective of Tatsumi Sekiguchi, a depressed man who writes for tabloid magazines to make ends meet, it takes readers through the world of post-war Tokyo as he and his eccentric friends attempt to solve the mystery of a woman, Kyoko Kuonji, who has been pregnant for 20 months and the suspicious disappearance of her husband, Makio.

Kyogokudo, Sekiguchi's friend and self-proclaimed atheist Onmyōji/book seller, scoffs at the possibility of a woman being pregnant for 20 months, explaining, "there is nothing strange in this world, Sekiguchi." ${ }^{215}$ Like philosopher Inoue Enryō, Kyogokudo (Figure 5.8) explains that there are scientific, and sometimes psychological, explanations to the mysteries of this world. However, this does not stop the both of them from discussing in detail the ubume after Sekiguchi happens to glance at a copy of Toriyama Sekien's version. Kyogokudo proposes that she is not the spirit, or manifestation of regrets, of a woman who has died during pregnancy. Rather, she is the image of the living's fears and regrets. Kyogokudo has imposed a modern day view on yōkai in his explanation.

Of course, that does not immediately address the issue of the pregnant woman and her missing husband. Sekiguchi is pulled deeper and deeper into the case, dragging Kyogokudo and their other friends along with him. In the end, a tragic and bloody family

${ }^{215}$ Kyōgoku, The Summer of the Ubume, 14. 
history is revealed. The Kuonji family had a history of giving birth to acephalous babies, or babies with no brain. As explained in the novel, and evidenced by other examples of Japanese folklore, babies with an unusual birth were sometimes considered ill omens. ${ }^{216}$ Because of this, the female lineage of the family would kill these babies with a stone shortly after they were born, earning them a less than desirable reputation as a cursed family.

The Summer of the Ubume is a historical and psychological analysis of folklore's place within society disguised as mystery novel. Kyōgoku combines the pitiful figure of the ubume who has lost a child with that of the malicious kokakucho ${ }^{217}$ who steals other women's children because she lost her own. Sekiguchi is swept up in the supernatural aspects and questions the reality he thought he knew throughout the novel. However, in the end, Kyogokudo lifts the "curse" that is on the Kuonji family by forcing everyone else to see the situation as it really is: a lineage of women doomed to repeat the mistakes of their mothers. Kyōko was never pregnant; there was nothing in her swollen belly. Ryōko suffered from psychotic breaks during which she sought to remedy the death of her own child by stealing infants from other women and killing them. And Makio, Kyōko's husband, was never missing. Kyōko stabbed him and she had been sleeping next to his corpse for the past 20 months.

\footnotetext{
${ }^{216}$ The novel also addresses the inverse of this, legends surrounding successful monks or exceptionally strong warriors that are applied retroactively to those individuals as a way to explain their awesomeness. This is not unlike the theme of the baby being cared for by the kosodate yürei growing up to be a remarkable person or the person who agrees to take the baby from the ubume being rewarded with great strength.

${ }^{217}$ Based on the monster of Chinese legend.
} 


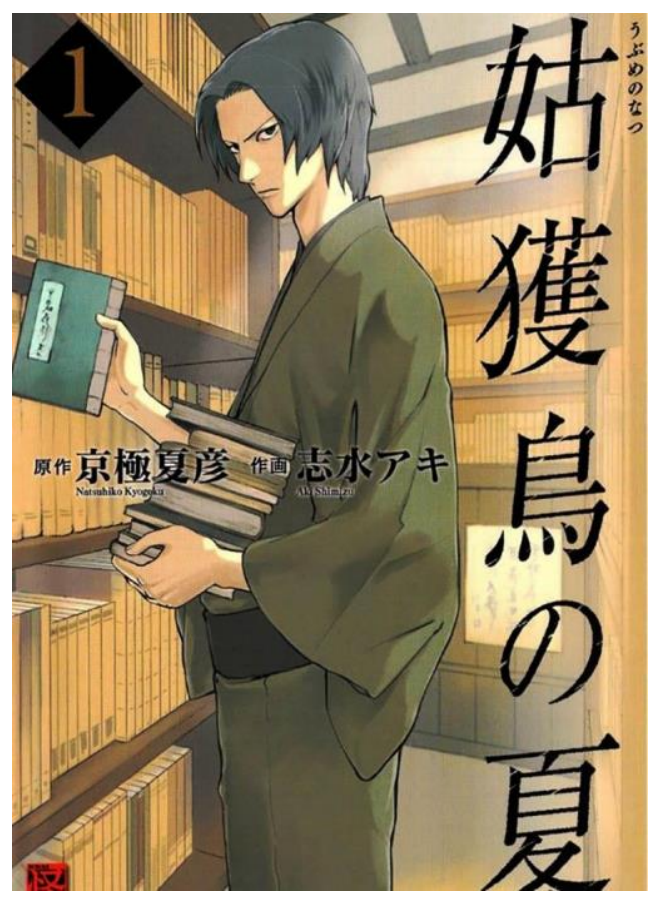

Figure 5.8: Cover of volume one of the manga adaptation of The Summer of the Ubume (姑獲鳥の夏), featuring Kyogokudo. ${ }^{218}$

Via these palpable characters, both pitiful and repulsive in their actions, Kyōgoku forces the reader to question not only the way in which we view folklore in contemporary society but our own humanity, the very purpose of yōkai as the inverse of humanity. What makes the novel so potent is the way in which it uses fantastical elements in the "real" 219 historical setting of Tokyo in the 1950s. Sekiguchi becomes fixated on the ubume, and at one points wonders, as he walks home at night, if she might be right behind him. The Kuonji family feels they are under a curse, while others feel the Kuonji family has cursed them. Kyogokudo must resort to supernatural means to explain everything to them by playing into their delusions. In the end, however, there was

\footnotetext{
${ }^{218}$ Scan provided by author.

${ }^{219}$ Susan J. Napier, The Fantastic in Modern Japanese Literature: The Subversion of Modernity (New York: Routledge, 1996), 5.
} 
nothing supernatural about the mysteries that unfolded. No yōkai, just monstrous individuals.

\section{The Call is Coming from Inside the House!}

The films that embody similar elements to The Summer of the Ubume, such as the monstrous mother and the subversion of the familiar, can also be analyzed in a similar way. While many of them contain more overt supernatural elements, such as yōkai and yūrei (as opposed to the delusion of the characters in the novel), they derive ideological potency from their closeness to reality.

While the Blood Pool Hell and the broader salvation of women is not as pressing to contemporary members of Japanese society, the family is. As a low-birth rate and aging society, Japan is facing a crisis that goes far beyond economic implications, and the role of women is continually conflated with that of mother. However, women are also working more, sometimes in order to save up for goals such as marriage and childrearing. This has been referred to as "the young woman's double burden." 220 The themes of anxiety surrounding pregnancy, pressures to reproduce, and filial duty that the ubume embodies are still there but they appear in different ways. Folklore does not alleviate societal pressures by explaining them in images of yōkai and yūrei, as it did in the past. Of course, healing is a part of pregnancy in that a women's state is changed completely but with medical advances, the fear of pregnancy resulting in death for the women (and child) is not as prevalent. The "fears," which are more like personal concerns, have shifted to result in the proliferation of mizuko kuyō practices and anxieties related to

\footnotetext{
${ }^{220}$ Kayoko Komatsu, “Spirituality and Women in Japan,” Japanese Journal of Religious Studies, 44 no. 1 (2017): 125. Retrieved from http://nirc.nanzan-u.ac.jp/nfile/4578.
} 
children that do not even exist yet - the children women are supposed to be having, fueled by the low-birth rate. The terror of the unborn.

These anxieties related to the family are consistently played out in horror films, the (relatively) new medium in which the monstrous shines. Some of the most potent films "situate the threat to the family as coming from within rather than outside." In Western examples, such as The Shining "the sins of the father, as monstrous other," 221 are emphasized. In Japanese films, by contrast, "it is the sins of the mother, and her daughter as her double, that return to threaten the home as microcosm of society, signifying the persistence of trauma, both historical and economic."222

As Colette Balmain points out, these Japanese films threaten the traditional ie family system of Japan within the context of the shift to "the Western nuclear form."223 Good wives and wise mothers, whether being attacked or doing the attacking, proliferate in the contemporary horror film genre in Japan. In short, these films "interrogate the changing shape of the family in contemporary Japan. The domestic space, uchi, which is connected to ideas of the sacred, becomes instead a place of horror and terror... unlike in Godzilla, in which the threat is mainly associated with the profane spaces of the outside (soto), the threat is now inside and knocking on the last bastion of Japanese patriarchy: the family embedded within the wider community."224

\footnotetext{
${ }^{221}$ Colette Balmain, "Haunted Houses and Family Melodramas," in Introduction to Japanese Horror Film, (Edinburgh: Edinburgh University Press, 2008): 128, accessed December 10, 2017, www.jstor.org/stable/ 10.3366/j.ctt1g09x15.14.

${ }^{222}$ Ibid.

${ }^{223}$ Ibid.

${ }^{224}$ Ibid., 129.
} 
A complete analysis of the Japanese family or the popularity of Japanese horror films is beyond the scope of this thesis. However, as figures such as yōkai and yūrei have migrated from twilight bridges and mountains at dusk to the portable worlds of television, comics, and videogames, so too have the fears they embody entered the home. These themes, as we have seen with the literature, paintings and kabuki dramas discussed, are not new. But, as the quote at the beginning of this chapter summarizes, they will persist. Given the perpetually dismal reality of gender inequality in Japan and the anxieties that come with a low-birthing and aging society, the metanarratives surrounding birth narratives are not likely to diminish any time soon.

In terms of the ubume specifically, this apparition transforms the natural (albeit at times uneasy) process of reproduction and the familiar figure of the mother into a monster and source of fear. Not surprisingly, films that "combine elements from Japanese mythology and Buddhist teachings on death, karma, and the supernatural with high technology and an ultramodern veneer," are exceedingly popular. And films that include the "Uncanny Mother""225 are particularly palpable.

Similar to the "between a rock and a hard place" situation women find themselves in concerning work and motherhood, particularly whether or not to postpone childbearing or leave work to raise a family, cultural representations of mothers have a dual nature: "over-valorisation" or the "demonic or nightmare mother." Not surprisingly, the demonic

${ }^{225}$ Ruth Goldberg, "Demons in the Family: Tracking the Japanese "Uncanny Mother Film" from A Page of Madness to Ringu" in Planks of Reason: Essays on the Horror Film, ed. Barry Keith Grant and Christopher Sharrett (Oxford: Scarecrow Press, Inc., 2004), 371. Goldberg uses Freud's concept of uncanny in reference to the maternal characters in these films. 
mother figures more frequently in today. ${ }^{226}$ The ubume is less explicitly depicted as she once was in Tokugawa period visuals and is not often portrayed in films as a sorrowful woman soaked in blood, begging someone to take her ghostly infant. Those crossing bridges at dusk need not look over their shoulder in fear. Nor do shopkeepers need to be on the lookout for dead women coming into their stores to purchase candy for their living offspring with dead leaves. As the films discussed below show, the monstrous mother is in the home, where one is supposed to feel most safest.

Kiyoshi Kurosawa's depiction of motherhood with the character Lady Mamiya in the 1989 film Sweet Home is a prime example of a modern day ubume. Instead of trying to pass her ghostly child off to the living who venture into her home, "her maternity becomes monstrous as she attempts to fulfil the maternal bond, even after her child's death, by providing other children to accompany her child in the afterworld," after unwittingly killing her. While pregnancy did not result in the death of the mother or the child in this tragedy, I argue that the narrative can still be construed of as an ubume narrative, with modernity transforming her from a generally innocuous entity into one of malice. Additionally, the source of fear comes from within the home, not outside of it. Balmain, using terms attributed to Stephen King and Carol J. Clover, respectively, refers to the Mamiya house as a "Bad Place" or "Terrible Place," to demonstrate that not only "are we most vulnerable in our homes..." but that "the promise of a safe haven turns into

${ }^{226}$ Balmain, "Haunted Houses and Family Melodramas," 129-130. 
one of horror." But the story is also tragic, in that Lady Mamiya accidentally killed her daughter that she had loved. ${ }^{227}$

Another film Balmain discusses, Carved, was inspired by another yōkai, the kuchisake onna, or slit-mouthed woman. However, the film portrays the ghost similar to the Chinese version of the ubume, the guhuoniao, which, although also the ghost of a woman who died without bearing children, steals the living children of other mothers. In the film, the kuchisake onna "possesses other mothers in order to carry out her bloody deeds" of harming children. ${ }^{228}$ Unlike in other examples, this monster terrorizes outside the home, but attacks something that is immensely personal: the family. Or, put in another way, the patriarchy.

\section{Summary}

In Japan, while figures of folklore such as yōkai and yūrei are still prominent, in media and beyond, they no longer offer explanations for the mysterious. Perhaps Kyogokudo explained it best when he summed up the ubume as a manifestation of the livings fears and regrets, not the dead's. ${ }^{229}$ In the past, the ubume was indeed thought of as the regrets of a deceased mother. While the relationship between the living and the dead is still prominent in Japanese culture, religiosity focuses, generally, more on this life than the afterlife, at least in terms of maternal concerns.

While religious practices no longer focus so much on the salvation of women from a specific hell, and medical advances have alleviated the concerns related to the

\footnotetext{
${ }^{227}$ Ibid., 131-132.

${ }^{228}$ Ibid., 133.

${ }^{229}$ Kyōgoku, The Summer of the Ubume, 40.
} 
ubume and kosodate yūrei, the ideology of motherhood has led to the prominence of sacred spaces related to maternity, as well as the popularity of the monstrous mother in literature and horror movies. 


\section{CONCLUSION}

“Oh. It's dark. I can't see my feet.

If I can't see them, I don't know what's going on down there.

Anything 's possible.

An ubume, the lower half of her body glistening with blood, could be

standing in the darkness behind me.

And that wouldn't be strange at all.

Is she? ${ }^{230}$

In The Summer of the Ubume, Kyogokudo, a mix of Inoue Enryō and Abe no Seimei, two influential figures in the world of Japanese folklore, forces Sekiguchi, and in turn the readers, to question the way we view the world. Historically, figures such as yōkai and yūrei developed as attempts to form a worldview, taking the place of the uneasiness that the mysterious forces us to confront. Their popularity, use, and even the language ascribed to them changes with each invocation of their forms, providing us with invaluable insight into the culture of individuals living in a given time period.

\section{Retracing the Ubume}

The ubume began her journey into the fixed pantheon of yōkai around 1120 when she was confined to the pages of the Konjaku monogatari. However, this would not have been enough to warrant the repetition in which she was invoked during the arts of the Tokugawa period, nor would it have been enough to spur the development of rituals such as mifutatsu and the nagare kanjō. Entire areas developed out of these practices, such as

\footnotetext{
${ }^{230}$ Kyōgoku, The Summer of the Ubume, 52. These are Sekiguchi's thoughts as he walks home from his enigmatic friend's house in the dark.
} 
the Shōsenji temple and town surrounding it, or more obviously, the town of Ubume in Shizuoka, home to the Ubume Kannon Temple.

By tracing the chronology of such a figure, it becomes clear that the ubume narrative informed, and was formed by, the metanarrative. In other words, the general attitudes towards the dead, mainly notions of tatari (spirt attacks) and the anxieties of muenbotoke (spirits with no relations), merged with the attitudes towards women and the female body, creating a specific afterlife for women who died either during pregnancy or childbirth. These were further enforced by the notions of impurity (specifically of blood), karmic retribution (immediate and after death), and specific hells for certain transgressions.

It becomes a bit of "chicken or the egg" dilemma when trying to determine exactly what came first. Based on the language of the Konjaku, we know that the chapter in which the ubume appears consisted of stories most likely derived from Japanese vernacular culture. Put another way, by process of elimination, we can make an educated guess that that chapter did not derive inspiration from previous histories or sutras. We also know that in order for setsuwa to function (mainly, to make more easily accessible the teachings of Buddhism), they had to be relatable to the audience. From this, we can assume that whoever compiled the Konjaku did not make up the figure of the ubume, regardless of whether or not people believed it was actually a fox playing tricks or a woman who died during pregnancy.

Whatever the case, by the time Banryō included the illustration of the ubume passing her baby off to Suetake in his edited Tokugawa version of the Konjaku, and removed the part that she may have been a fox, her figure was already recognizable. I 
argue that the religious ramifications surrounding maternity contributed to the popularity of the ubume trope, which became so popular that by the 1800s one author lamented that she was invoked too often. In an illustration meant to be comedic, she was drawn with a ghostly husband who proclaims, "You! You're just a female ghost, but you're an incredibly immodest one! You've been popping up totally randomly... and as a result no one takes us ghosts seriously anymore."231

But ghosts do not pop up randomly. In the past, they were real figures that inspired fear and action to be taken in this life to prevent becoming one and from interacting with one. They were also used, in instances like setsuwa, to convey moral messages related to Buddhism. Beginning in the Tokugawa period, while they were still feared (especially in the case of the ubume and kosodate yūrei), they became objects of entertainment, at times removed from any religious connotations. Following the Tokugawa period, Yanagita Kunio, who worked mainly in the early 1900s, sought to commit as much as he could of oral tradition associated with the Tono region to paper in fear that they would be lost. Inoue Enryō, in contrast, sought to eradicate people's beliefs in the supernatural, which he saw as a hindrance to the advancement of Japan into modernity. However, by spreading the notion that yōkai were "unscientific," ${ }^{, 32}$ he inevitably preserved the idea of what a yōkai was.

\footnotetext{
${ }^{231}$ Shimazaki, "Figures of the Ubume and the Breakdown of Theater Tradition," 219-221.

${ }^{232}$ Masayuki Ikeda, "Messages from yurei and yokai-Koizumi Yakumo and Inoue Enryo on yokai."
} 


\section{Further Research}

During the Nanbokuchō period (1336-1392), a wooden statue of a seated Jizō

Bodhisattva was carved. In 1678, to memorialize his dead son, "a merchant by the name of Obiya," put two of his sons books inside the statue, to ensure "the boy's connection to Jizō in the afterworld." Even though the books inside were discovered in 1915, they were "largely disregarded until 1980," when a scholar insisted they be reexamined. ${ }^{233}$ Dated between the years 1667-1677, the books give scholars valuable insight into the "reading material that would have been deemed appropriate for merchant-class boys" of that time. In their case, they included "monsters, anthropomorphic animals, silly jokes, and violence," and in one tale "two men who, in parallel dreams, ran away from the same blood-stained ubume 産女 (the ghost of a woman who died in childbirth)."234

What this example shows is that new discoveries always await. We may one day find yet an older extent copy of the Ketsubonkyō or a textual reference to an ubume that predates the. The crisis Japan is facing in terms of its aging population and low-birth rate is not going to be alleviated any time soon, which means gender, and more specifically maternity, will continue to be a contentious issue in contemporary Japan. The ideology of motherhood and stigmatization of non-reproduction persist. As Foster points out, "we humans have created monsters over which we have no control." ${ }^{235}$ Yōkai, and to an extent more overtly religious figures such as Kannon, cannot easily answer or stand in for

${ }^{233}$ R. Keller Kimbrough, "Bloody Hell!: Reading Boys' Books in Seventeenth-Century Japan,” Asian Ethnology 74, no. 1 (2015): 112, accessed July 12, 2017, http://www.jstor.org/stable/43610654.

${ }^{234}$ Ibid., 118.

${ }^{235}$ Foster, The Book of Yōkai, 243-245. 
the problems of the twenty first century. However, when examined empirically, they offer insight into how those problems arose. 


\section{BIBLIOGRAPHY}

Ambros, Barbara R. Women in Japanese Religions. New York and London: New York University Press, 2015.

Averbuch, Irit. "Discourses of the Reappearing: The Reenactment of the "Cloth-Bridge Consecration Rite" at Mt. Tateyama." Japanese Journal of Religious Studies 38, no. 1 (2011): 1-54. Accessed December 12, 2017. http://www.jstor.org/stable/41229968.

Balmain, Colette. "Haunted Houses and Family Melodramas." In Introduction to Japanese Horror Film, (Edinburgh: Edinburgh University Press, 2008): 128. JSTOR, www.jstor.org/stable/10.3366/j.ctt1g09x15.14.

Beauvoir, Simone de. The Second Sex. New York: Vintage Books, 1973.

Bendix, Regina. "Folklorism: The challenge of a concept." International Folklore Studies, 6 (1988), S. 5-15.

Bennett, Gillian, Alas, Poor Ghost!: Traditions of Belief in Story and Discourse. Utah: Utah State University Press, 1999.

Central Intelligence Agency. "The World Factbook - Country Comparison: Infant Mortality Rate." Accessed December 17, 2017.

https://www.cia.gov/library/publications/the-worldfactbook/rankorder/2091 rank.html

—_ "The World Factbook - Country Comparison: Maternal Mortality Rate." Accessed December 17, 2017. https://www.cia.gov/library/publications/theworld-factbook/rankorder/2223rank.html

Chödrön, Pema. The Wisdom of No Escape: And the Path of Loving-Kindness. Boston: Shambhala Publications, 1991.

Davidsen, Markus Altena. (2016) Fiction and Religion: How Narratives About the Supernatural Inspire Religious Belief - Introducing the Thematic Issue, Religion, 46:4, 489-499, DOI:10.1080/0048721X.2016.1226756.

Deal, William E. and Brian Ruppert. A Cultural History of Japanese Buddhism. West Sussex: Wiley, 2015.

Digital Collections of Keio University Libraries. “幽霊之困 うぶめ.”Accessed September 2, 2017. http://dcollections.lib.keio.ac.jp/ja/ukiyoe/1173.

Dumas, Raechel. "Historicizing Japan's Abject Femininity: Reading Women's Bodies in "Nihon Ryōiki"." Japanese Journal of Religious Studies 40, no. 2 (2013): 247275. Accessed March 4, 2017. http://www.jstor.org/stable/23595655. 
Editors of Encyclopædia Britannica. "Kabuki.” April 25, 2017.

https://www.britannica.com/ art/Kabuki.

Eubanks, Charlotte. "Illustrating the Mind: "Faulty Memory" Setsuwa and the Decorative Sutras of Late Classical and Early Medieval Japan." Japanese Journal of Religious Studies 36, no. 2 (2009): 209-230. Accessed September 2, 2017. http://www.jstor.org/stable/40660966.

Foster, Michael Dylan. The Book of Yōkai. Oakland: University of California Press, 2015.

_ . "The Metamorphosis of the Kappa: Transformation of Folklore to Folklorism in Japan." Asian Folklore Studies 57, no. 1 (1998): 1-24. doi:10.2307/1178994.

Glassman, Hank. "At the Crossroads of Birth and Death: The Blood Pool Hell and Postmortem Fetal Extraction." In Death and the Afterlife in Japanese Buddhism, edited by Jacqueline I. Stone and Mariko Namba Walter, 175-206. Honolulu: University of Hawaii Press, 2008.

Goldberg, Ruth. "Demons in the Family: Tracking the Japanese "Uncanny Mother Film" from A Page of Madness to Ringu." In Planks of Reason: Essays on the Horror Film, edited by Barry Keith Grant and Christopher Sharrett, 371. Oxford: Scarecrow Press, Inc., 2004.

Hardacre, Helen. Marketing the Menacing Fetus in Japan. Berkeley: University of California Press, 1997.

—. Shinto: A History. New York: Oxford University Press, 2017.

Hickman, Money L. "Views of the Floating World." MFA Bulletin 76, (1978): 4-33. Accessed December 10, 2017, http://www.jstor.org/stable/4171617.

Iwasaka, Michiko, and Barre Toelken. Ghosts and the Japanese: Cultural Experience in Japanese Death Legends. Logan: Utah State University Press, 1994.

Jackson, Rosemary. Fantasy: The Literature of Subversion. New York: Routledge, 2003.

Jansen, Marius B. China in the Tokugawa World. Cambridge: Harvard University Press, 1992.

Jones, Sumie and Kenji Watanabe. An Edo Anthology: Literature from Japan's MegaCity, 1750-1850. Honolulu: University of Hawaii Press, 2013.

Jordan, Brenda. "Yūrei: Tales of Female Ghosts", in Japanese Ghosts \& Demons, edited by Stephen Addiss, 25. New York: George Braziller, 1985.

Josephson, Jason Ananda. The Invention of Religion in Japan. Chicago: University of Chicago Press, 2012. 
Kaminishi, Ikumi. Explaining Pictures: Buddhist Propaganda and Etoki Storytelling in Japan. Honolulu: University of Hawaii Press, 2006.

Kamiya, Setsuko. "Last rites for the memories as beloved dolls pass away." The Japan Times, October 15, 2006. https://www.japantimes.co.jp/life/2006/10/15/to-besorted/last-rites-for-the-memories-as-beloved-dolls-pass-away/\#.Wmj4J6inHIU.

Kasulis, Thomas P. Shinto: The Way Home. Honolulu: University of Hawaii Press, 2004.

Kawamori, Hiroshi. "Folktale Research after Yanagita: Development and Related Issues." Asian Folklore Studies 62, no. 2 (2003): 237-256. Accessed November 15, 2016. http://www.jstor.org/stable /30030288.

Kim, Jieun "Necrosociality: Isolated Death and Unclaimed Cremains in Japan." Journal of the Royal Anthropological Institute 22 (2016): 843-863. Accessed November 11, 2017. http://onlinelibrary.wiley.com/doi/10.1111/1467-9655.12491/full.

Kimbrough, R. Keller. "Bloody Hell!: Reading Boys' Books in Seventeenth-Century Japan." Asian Ethnology 74, no. 1 (2015): 112. http://www.jstor.org/stable/43610654.

Komatsu, Kayoko. "Spirituality and Women in Japan." Japanese Journal of Religious Studies, 44 no. 1 (2017): 125. Retrieved from http://nirc.nanzanu.ac.jp/nfile/4578.

Komatsu, Kazuhiko. An Introduction to Yōkai Culture. Tokyo: JPIC, 2017.

Koriyama, Naoshi and Bruce Allen. Japanese Tales from Times Past. North Clarendon: Tuttle Publishing, 2015.

Kunihiko, Tsutsumi, "Kosodate yūrei tan no genzō Sōtō shū sōsō girei wo tegakari to shite," Kyoto Seika daigaku kiyō 93, no. 1.

Kurosawa, Kōzō. "Myths and Tale Literature." Japanese Journal of Religious Studies 9, no. 2/3 (1982): 115-125. Accessed December 10, 2017. http://www.jstor.org/stable/30233943.

Kyōgoku, Natsuhiko. The Summer of the Ubume. New York: Vertical, 1994.

Kyōkai. Record of Miraculous Events in Japan. Translated by Burton Watson. New York: Columbia University Press, 2013.

LaFleur, William R. Liquid Life: Abortion and Buddhism in Japan. Princeton: Princeton University Press, 1992. 
Masayuki, Ikeda. "Messages from Yūrei and Yōkai — Koizumi Yakumo and Inoue Enryo on Yōkai." Yomiuri Shimbun. Accessed September 20, 2017. http://www.yomiuri.co.jp/adv/wol/dy/opinion/ culture_150924.html.

McDowell, John H. "Rethinking Folklorization in Ecuador: Multivocality in the Expressive Contact Zone." Western Folklore 69, no. 2 (2010): 182. Accessed January 6, 2018. http://www.jstor.org/stable/27896341.

Moerman, D. Max. "A Woman's Place." In Localizing Paradise: Kumano Pilgrimage and the Religious Landscape of Premodern Japan. Cambridge (Massachusetts); London: Harvard University Asia Center, 2005. Accessed July 10, 2017. http://www.jstor.org/stable/j.ctt1tg5mth.10.

Mori, Masato. "'Konjaku Monogatari-shū": Supernatural Creatures and Order." Japanese Journal of Religious Studies 9, no. 2/3 (1982): 147-170. Accessed June 10, 2017. http://www.jstor.org/stable/30233945.

Napier, Susan J. The Fantastic in Modern Japanese Literature: The Subversion of Modernity. New York: Routledge, 1996.

Nemoto, Kumiko. "Postponed Marriage: Exploring Women's Views of Matrimony and Work in Japan." Gender and Society 22, no. 2 (2008): 219-237. Accessed October 1, 2017. http://www.jstor.org/stable/27821634

Purcell, Theobald A. "Our neighborhood", or, Sketches in the suburbs of Yedo. Yokohama, 1874.

Reider, Noriko T. "The Appeal of "Kaidan", Tales of the Strange." Asian Folklore Studies 59, no. 2 (2000): 266. doi:10.2307/1178918.

_. Japanese Demon Lore: Oni. Utah: Utah State University Press, 2010.

- Seven Demon Stories from Medieval Japan. Logan: Utah State University Press, 2016.

—. "Tsuchigumo Sōshi: The Emergence of a Shape-Shifting Killer Female Spider." Asian Ethnology 72, no. 1 (2013): 55-83. Accessed December 10, 2017. http://www.jstor.org/stable/41958916.

Richko, Rebecca L. "Social and Economic Factors Influencing Japanese Women's Decision about Childbearing in Post-Bubble Japan" (2016). FIU Electronic Theses and Dissertations. 2451. Accessed July 15, 2017. http://digitalcommons.fiu.edu/etd/2451.

Roesch, S.C., Dunkel Schetter, C., Woo, G., \& Hobel, C.J. (2004). Modeling the types and timing of stress in pregnancy. Anxiety, Stress, and Coping, 17(1), 87-102. 
Schumacher, Mark. "Jizō Bosatsu (Japanese) Ksitigarbha Bodhisattva (Sanskrit)." Onmark Productions. Accessed December 10, 2017, http://www.onmarkproductions.com/html/jizo1.shtml.

. "Kannon Bodhisattva, Kannon Bosatsu, Lord of Compassion, Goddess of Mercy." Onmark Productions. Accessed November 30, 2017. http://www.onmarkproductions.com/html/kannon.shtml.

_. "Shrines by Type, Shrines by Kami (Deity)." Onmark Productions. Accessed November 30, 2017. http://www.onmarkproductions.com/html/shrineguide.shtml\#tenjin.

—. "Suijin 水神, Suiten 水天, Sui-̄̄ 水王." Onmark Productions. Accessed November 30, 2017. http://www.onmarkproductions.com/html /suijin.html.

Shimamura, Takanori. "Cultural Diversity and Folklore Studies in Japan: A Multiculturalist Approach." Asian Folklore Studies 62, no. 2 (2003): 195-224. Accessed November 15, 2016. http://www.jstor.org/stable/30030286.

Shimazaki, Satoko. "THE END OF THE WORLD: Figures of the Ubume and the Breakdown of Theater Tradition." In Edo Kabuki in Transition: From the Worlds of the Samurai to the Vengeful Female Ghost. New York: Columbia University Press, 2016. Accessed April 10, 2017. http://www.jstor.org/stable/10.7312/shim17226.9.

— . "The Ghost of Oiwa in Actor Prints: Confronting Disfigurement." Impressions, no. 29 (2007): 78-79. Accessed July 13, 2017. http://www.jstor.org/stable/42598014.

Shirane, Haruo. Introduction to Record of Miraculous Events in Japan, 1-5. Translated by Burton Watson. New York: Columbia University Press, 2013.

Smith, Robert. "On Certain Tales of the "Konjaku Monogatari" as Reflections of Japanese Folk Religion." Asian Folklore Studies 25 (1966): 221-233. doi: $10.2307 / 1177479$.

Smith, Thomas C., Robert Y. Eng, and Robert T. Lundy, Nakahara: Family Farming and Population in a Japanese Village, 1717-1830. Stanford: Stanford University Press, 1977.

Stone, Jacqueline I. and Mariko Namba Walter, Death and the Afterlife in Japanese Buddhism. Honolulu: University of Hawaii Press, 2008.

Takemi, Momoko. "'Menstruation Sutra" Belief in Japan." Japanese Journal of Religious Studies 10, no. 2/3 (1983): 229-246. Accessed March 10, 2017. http://www.jstor.org/stable/30233304. 
Traganou, Jilly. The Tōkaidō Road: Traveling and Representation in Edo and Meiji Japan. New York: RoutledgeCurzon, 2004.

Ury, Marian. Tales of Times Now Past. Ann Arbor: The University of Michigan, 1979.

Vaporis, Constantine Nomikos. "Assignment: Edo." In Tour of Duty: Samurai, Military Service in Edo, and the Culture of Early Modern Japan, 102-127. University of Hawai'i Press, 2008. Accessed December 10, 2017. http://www.jstor.org/stable/j.ctt6wqtsd.8.

Williams, Duncan Ryūken. The Other Side of Zen: A Social History of Sōtō Zen Buddhism in Tokugawa Japan. Princeton: Princeton University Press, 2005.

Wilson, William Ritchie. "The Way of the Bow and Arrow. The Japanese Warrior in Konjaku Monogatari." Monumenta Nipponica 28, no. 2 (1973): 177-233. doi:10.2307/2383862.

Yamamoto, Akira Y. Introduction to Japanese Ghosts \& Demon: Art of the Supernatural, 9-12. Edited by Stephen Addiss. New York: George Braziller, Inc., 1985.

Yasui, Manami. "Research Notes: On Burial Customs, Maternal Spirits, and the Fetus in Japan." U.S.-Japan Women's Journal, no. 24 (2003): 102-114. Accessed May 7 , 2017. http://www.jstor.org/stable/42771896. 